\title{
Hydrologic Resources Management Program and Underground Test Area FY 1998 Progress Report
}

\author{
D.K. Smith, G.F. Eaton,
}

F.C. Benedict, Jr., R.E. Criss, M.L. Davisson, G.B. Hudson,

J.M. Kenneally, T.P. Rose

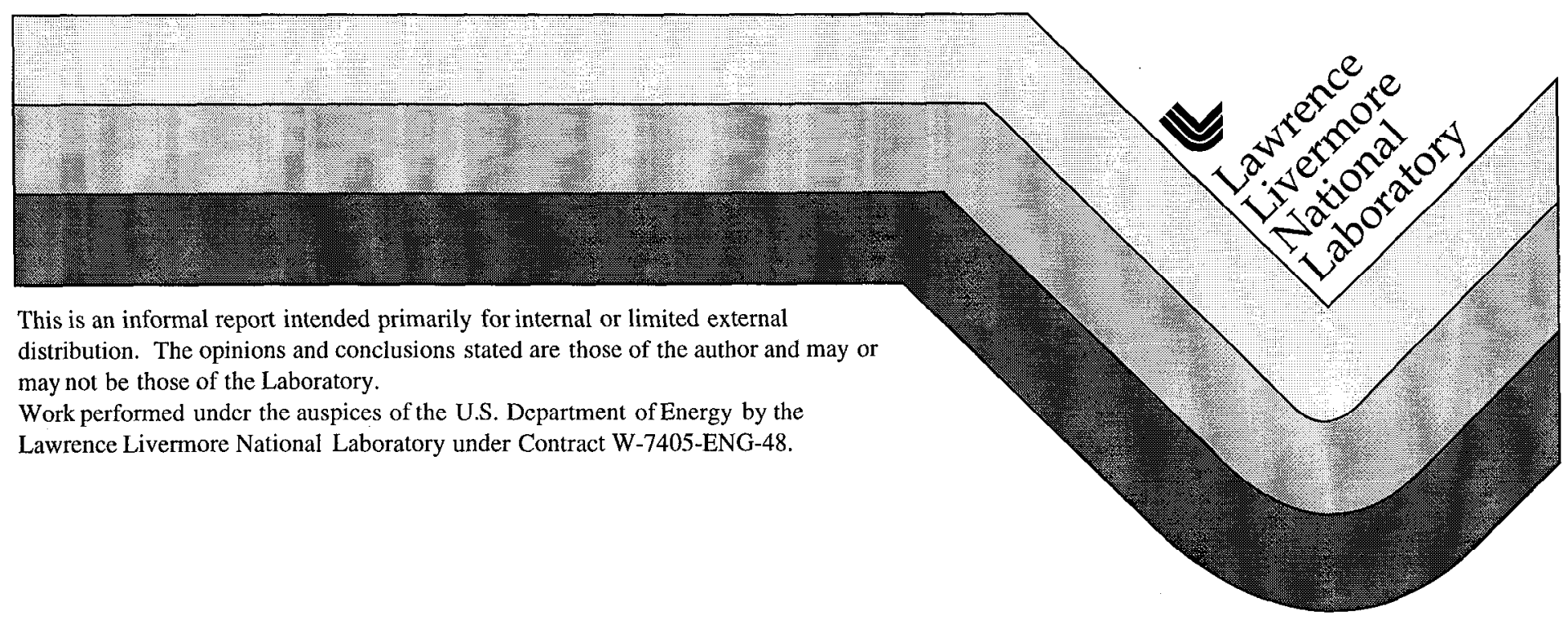





\section{DISCLAIMER}

This document was prepared as an acccount of work sponsored by an agency of the United States Government. Neither the United States Government nor the University of California nor any of their employees, makes any warranty, express or implied, or assumes any legal liability or responsibility for the accuracy, completeness, or usefulness of any information, apparatus, product, or process disclosed, or represents that its use would not infringe privately own rights. Reference herein to any specific commercial products, process, or service by trade name, trademark, manufacturer, or otherwise, does not necessarily constitute or imply its endorsement, recommendation, or favoring by the United States Government or the University of California. The views and opinions of authors expressed herein do not necessarily state or reflect those of the United States Covernment or the University of California, and shall not be used for advertising or product endorsement purposes.

This report has been reproduced directly from the best available copy.

Available to DOE and DOE contractors from the Office of Scientific and Technical Information P.O. Box 62, Oak Ridge, TN 37831

Prices available from (615) 576-8401, FIS 626-8401

Available to the public from the National Techrical Irformation Service

US. Department of Commerce 5285 Port Royal Rd., Springfield, VA 22161 



\title{
Hydrologic Resources Management Program and Underground Test Area FY 1998 Progress Report
}

\author{
Editors: \\ David K. Smith \\ Gail F. Eaton

\section{Contributors:} \\ F. Christopher Benedict, Jr.* \\ Robert E. Criss** \\ M. Lee Davisson \\ Gail F. Eaton \\ G. Bryant Hudson \\ Jacqueline M. Kenneally \\ Timothy P. Rose \\ David K. Smith
}

July 1999

* HSI GeoTrans, Reno, Nevada

** Washington University, St. Louis, Missouri 



\section{TABLE OF CONTENTS}

Introduction

Chapter 1

Chapter 2

Chapter 3

Chapter 4

Chapter 5

Chapter 6
FY1998 HRMP Report

i

FY 1998 Sampling and Analysis at CHESHIRE (U-20n PS1 DD-H)

1

7 Analyses at CAMEMBERT (U19q-PS1 D)

FY 1998 Hot Well Sampling

15

Aged Nuclear Explosive Melt Glass: Radiography

29 and Scanning Electron Microscope Analyses

Documenting both Radionuclide Distribution and Glass Alteration

Isotopic Investigation of Recharge to a Regional Groundwater Flow System, Great Basin, Nevada, USA

Stable Isotope and Radiocarbon Compositions of

Secondary Calcite from Pahute Mesa, Nevada Test

Site 



\section{Introduction}

This report presents the results from FY 1998 technical studies conducted by Lawrence Livermore National Laboratory (LLNL) as part of the Hydrology and Radionuclide Migration Program (HRMP) and Underground Test Area (UGTA) project. The HRMP is sponsored by Defense Programs (DP) of the U.S. Department of Energy, Nevada Operations Office (DOE/NV), and supports DP operations at the Nevada Test Site (NTS) through studies of radiochemistry and resource management related to the defense programs mission. Other participating organizations include the Los Alamos National Laboratory (LANL), the United States Geological Survey (USGS), the Desert Research Institute (DRI) of the University of Nevada, the United States Environmental Protection Agency (EPA), and Bechtel-Nevada (BN). The UGTA project is an Environmental Management (EM) activity of DOE/NV that supports a Federal Facilities Agreement and Consent Order between the Department of Energy, the Department of Defense, and the State of Nevada. UGTA's primary function is to address the legacy release of hazardous constituents at the Nevada Test Site, the Tonopah Test Range, and off-Nevada Test Site underground nuclear testing areas. Participating contractors include LLNL (Earth and Environmental Sciences Directorate, Analytical and Nuclear Chemistry Division), LANL, DRI, USGS, BN, HSI-GeoTrans, and IT Corporation.

The FY 1998 HRMP and UGTA annual progress report follows the organization and contents of our FY 1997 report (Smith et al., 1998), and includes our results from CY 1997 - 1998 technical studies of radionuclide migration and isotope hydrology at the Nevada Test Site. During FY 1998, LLNL continued its efforts under the HRMP to pursue a technical agenda relevant to the science-based stockpile stewardship program at DOE/NV. Support to UGTA in FY 1998 included efforts to quantitatively define the radionuclide source term residual from underground nuclear weapons testing and the derivative solution, or hydrologic source term, from radionuclides dissolved in or transported by groundwater. The hydrologic source term is a component of a predicted dose assessment for the five principal NTS testing areas.

The FY 1998 technical program for LLNL focused on defining the concentration of radionuclides transported in groundwater and controls on radionuclide migration. In addition, LLNL continued to apply both measurement and interpretative expertise to isotope studies of regional groundwater flow through southern Nevada, including the Nevada Test Site. The FY1998 studies highlighted in this report are as follows.

1) In Chapter 1, analytical results are reported for groundwater samples collected from the CHESHIRE post-shot hole U-20n PS1 DD-H. This well is one of only two pumped wells on the Nevada Test Site completed within a saturated nuclear test cavity. Water samples from U-20n PS 1 DD-H provide valuable insight regarding the hydrologic source term for older, high-yield nuclear tests conducted in fractured volcanic rocks of Pahute Mesa 
2) Groundwater samples were also pumped from re-entry well U-19q PS\#1 D, which was re-completed during 1998 in the collapse chimney of the CAMEMBERT nuclear test. This site is being investigated for the first time to assess radionuclide transport. The results of this investigation are reported in Chapter 2. The analytical data indicate that radionuclides, including plutonium, have migrated above the working point and into the chimney. However, gas chemistry, fluid chemistry and carbon isotope data suggest that the sampled part of the system does not readily exchange with the regional groundwater flow system.

3) The results of FY 1998 "hot well" sampling efforts are discussed in Chapter 3. This work is a collaborative effort between LLNL, LANL, and the USGS. During FY 1998, tandem Bennett pumps were successfully installed by Bechtel-Nevada in the narrow bore of a post-shot re-entry hole at the DALHART (U-4u PS 2a) site. The Bennett pump technology allows fluids to be pumped from outside the well bore, providing samples that are more representative of radionuclide concentrations within and adjacent to the chimney and test cavity. The report discusses hydrochemical and radiochemical results for water samples from three different sites. It is noteworthy that there is both chemical and isotopic evidence for "closed system" behavior at the ALEMENDRO (U-19v) site, similar to that observed at CAMEMBERT (U-19q).

4) Chapter 4 discusses an investigation of the radiochemistry, matrix chemistry, and alteration of nuclear explosive melt glass returned from the saturated zone by post-shot drilling more than ten years after the time of detonation. Of significance is the use of an $\alpha$-track radiography technique to map the distribution of actinides in these melt glasses.

5) An environmental isotope $\left({ }^{18} \mathrm{O} /{ }^{16} \mathrm{O},{ }^{2} \mathrm{H} /{ }^{1} \mathrm{H}\right)$ study of groundwater recharge processes in central Nevada is presented in chapter 5. A recent peer review publication by LLNL staff (Davisson et al., 1999) asserts that regional groundwater flow through much of the NTS originates as modern recharge from the north. To test this idea, samples of snowfall, runoff, alpine springs, and regional groundwaters were collected from inferred recharge areas north of the NTS. The analytical results tend to support the regional flow model of Davisson et al., and provide new insight into how recharge occurs, and where important recharge areas are located.

6) Lastly, Chapter 6 reports on the stable isotope and radiocarbon composition of secondary calcite $\left(\mathrm{CaCO}_{3}\right)$ that occurs on fracture linings within the volcanic rocks of Pahute Mesa. Stable isotope data were used to infer the origin and temperature of the fluids from which the calcite was precipitated. Radiocarbon data revealed that most of the calcite was $>40,000$ years in age. These results help to elucidate potential interactions between groundwater and the fractured rock aquifers, and provide necessary constraints for the prediction of groundwater ages and flow velocities in numerical groundwater flow models. 


\section{Other FY 1998 HRMP and UGTA Activities}

In addition to the activities described above, LLNL's HRMP and UGTA staff contributed to several other technical products during FY 1998. These products included:

1) The results of a multi-year HRMP sponsored study of $\delta^{18} \mathrm{O}$ and ${ }^{14} \mathrm{C}$ systematics in southern Nevada groundwaters was submitted to Water Resources Research in FY 1998, and published in early CY 1999 (Davisson et al., 1999). This study provides quantitative isotopic evidence for large-scale regional flow systems that were conceptualized in earlier studies (e.g. Eakin, 1966; Blankennagel and Weir, 1973; Winograd and Thordarson, 1975; Mifflin and Hess, 1979).

2) Building on Davisson et al.'s work, LLNL staff presented a paper entitled "Isotope Hydrology of Regional Groundwater Flow in Central and Southern Nevada" at the 1997 Fall Meeting of the American Geophysical Union in San Francisco. This paper reports the initial results from an isotopic investigation, designed and conducted by LLNL staff, of groundwater recharge and southerly flow through the Kawich and Railroad Valleys, north of the Nevada Test Site (Rose et al., 1997). This work was also discussed in the FY 1997 LLNL UGTA-HRMP report (Smith et al., 1998).

3) LLNL was asked to participate in an "Analogs Workshop," held in Las Vegas by the M \& O contractor for the Yucca Mountain Project. For this workshop, project staff reviewed past and current studies of radionuclide migration at the Nevada Test Site in the context of performance assessment of the proposed Yucca Mountain high-level nuclear waste repository.

4) Results from the studies of colloid-facilitated transport of plutonium from the BENHAM (U-20c) nuclear test site to the ER-20-5 Pahute Mesa well cluster, were submitted for peer-review in FY 1998 prior to their publication by Nature in January, 1999 (Kersting et al., 1999). These results were originally presented in the FY 1997 LLNL UGTA-HRMP report (Smith et al., 1998).

5) LLNL was invited by the International Atomic Energy Agency (IAEA) to present a paper entitled: "The Production and Dissolution of Nuclear Explosive Melt Glasses at Underground Test Sites in the Pacific Region." This paper provides an assessment of radionuclide migration associated with nuclear test sites on the atolls of Mururoa and Fangataufa in French Polynesia, and Amchitka Island in the Aleutian Island chain. This paper was presented at the International Symposium on Marine Pollution held in Monaco during October of 1998.

6) And finally, LLNL staff contributed their expertise to a one-day short course, designed for DOE/NV and affiliated personnel of DOE contractors, on radionuclide migration at the Nevada Test Site. This course was conducted in May of 1997, and videotaped by the $\mathrm{DOE} / \mathrm{NV}$ as part of their public affairs media library. 


\section{References}

Blankennagel, R.K., and Weir, J.E. (1973), Geohydrology of the eastern part of Pahute Mesa, Nevada Test Site, Nye County, Nevada. U.S. Geological Survey Professional Paper 712-B, 35 pp.

Davisson, M.L., Smith, D.K., Kenneally, J.M., and Rose, T.P. (1999), Isotope Hydrology of southern Nevada groundwater: Stable isotopes and radiocarbon. Water Resources Research, v. 35, no. 1, p. 279-294.

Eakin, T.E. (1966) A regional interbasin groundwater system in the White River area, southeastern Nevada. Water Resources Research, v. 2, p. 251-271.

Kersting, A.B., Efurd, D.W., Finnegan, D.L., Rokop, D.J., Smith, D.K., and Thompson, J.L. (1999), Migration of plutonium in groundwater at the Nevada Test Site. Nature, v. 397, p. 56-59.

Mifflin, M.D., and Hess, J.W. (1979), Regional carbonate flow systems in Nevada. Journal of Hydrology, v. 43, p. $217-237$.

Rose, T.P., Davisson, M.L., Kenneally, J.M., and Smith, D.K. (1997), Isotope Hydrology of Regional Groundwater Flow in Central and Southern Nevada. American Geophysical Union abstracts, v. 78, no. 46, p. 243.

Smith, D.K., Kersting, A.B., Rose, T.P., Kenneally, J.M., Hudson, G.B., Eaton, G.F. and Davisson, M.L. (1998), Hydrologic Resources Management Program and Underground Test Area Operable Unit FY 1997 Progress Report. Lawrence Livermore National Laboratory Internal Report, UCRL-ID-130792, $92 \mathrm{pp}$.

Winograd, I.J., and Thordarson, W. (1975), Hydrogeologic and hydrochemical framework, south-central Great Basin, Nevada-California, with special reference to the Nevada Test Site. U.S. Geological Survey Professional Paper 712-C, 126 pp. 


\title{
- Chapter 1 -
}

\section{FY 1998 Sampling and Analysis at CHESHIRE (U-20n PS1 DD-H)}

\author{
Isotopic Tracers and Transport Team
}

\section{Introduction}

In FY 1998, the Underground Test Area project re-completed the U-20n PS1 DD-H well within the CHESHIRE nuclear test cavity. This effort is significant since, despite 828 underground nuclear tests fired on the Nevada Test Site, the opportunity to pump water from a nuclear test cavity is extremely rare due to restrictions imposed by the depths, drilling conditions, radiation levels, and costs associated with these operations (Smith, 1998). The re-completion of U-20n PS1 DD-H provides access to pumped water from a high yield nuclear test cavity situated below the water table on Pahute Mesa. Because these cavity water samples are a measure of point-source concentrations of dissolved and suspended radionuclides available for subsequent down-gradient transport, these data are vital to predictions of radionuclide transport at the Nevada Test Site.

The CHESHIRE test was fired in emplacement hole U-20n on 14 February 1976 at a depth of 3829 feet $(1167 \mathrm{~m})$ beneath Pahute Mesa in Area 20 of the Nevada Test Site. The announced yield was between 200 - 500 kilotons, and the depth from ground surface to the pre-shot standing water level is $2050 \mathrm{ft}(625 \mathrm{~m})$. A post-shot re-entry hole, U-20n PS1 DD, was slant-drilled to a total depth of $4318 \mathrm{ft}(1316 \mathrm{~m})$ in fractured rhyolite of the saturated zone. Because the post-shot hole was slant-drilled, the wellhead is situated approximately $400 \mathrm{~m}$ from surface ground zero. Soon after the post-shot sampling was completed, the post-shot hole was converted to a monitoring and observation well, renamed U-20n PS1 DD-H, and intermittently sampled between 1976 and 1997. A comprehensive unclassified review of several studies concerning radionuclide migration at the CHESHIRE site, including historical data on the radiochemistry of waters collected from the upper and lower sampling intervals, is currently in preparation and will be published later this year (Sawyer et al., 1999).

Following the re-completion of the U-20n PS1 DD-H well in 1998, groundwater samples in close proximity to the detonation cavity were collected. Samples were collected from two distinct production levels using down-hole pumps (samples were previously obtained from U20n PS1 in 1996 and 1997 using a wire-line bailer). Following a purge volume of 10,322 gallons, the first sample (CH-980728) ${ }^{\mathrm{t}}$ was collected on $28 \mathrm{July} 1998$ from the perforation interval between $2665-2995 \mathrm{ft}(812-913 \mathrm{~m})$ which is located above a bridge plug. After drilling through this bridge plug, and following a purge volume of 215,000

\footnotetext{
${ }^{1}$ For data security purposes, a LLNL sample identification system has been instituted. CH-980728 indicates the CHESHIRE groundwater sample collected on July 28, 1998.
} 
gallons, the second sample (CH-980921) ${ }^{2}$ was collected on September 21, 1998. This sample was from the lower perforation level between $4100-4110 \mathrm{ft}(1250-1253 \mathrm{~m})$, within the test cavity. Tritium activities measured in the field using liquid scintillation counting are $3.9 \times 10^{7} \mathrm{pCi} / \mathrm{L}$ for $\mathrm{CH}-980728$ and $7.0 \times 10^{7} \mathrm{pCi} / \mathrm{L}$ for $\mathrm{CH}-980921$. The tritium values from both perforation levels are consistent with the proximity of U-20n PS1 DD-H to the CHESHIRE test, and have decreased only slightly since the upper perforation level was last sampled in 1996 and 1997 (Smith et al., 1998). The isotopic data for groundwater samples collected from the UGTA well line U-20n PS1 DD-H are presented in this chapter.

\section{Analytical Results}

Analytical results are tabulated with uncertainties and detection limits in Table 1. Laboratory analytical protocols for all analyses are found in standard operating procedures, written in support of the UGTA Program (ISD, 1995). Radionuclide data in this document are reported relative to the time of measure in 1998, and are not decay corrected.

\section{${ }^{3} \mathrm{H}-{ }^{3} \mathrm{He}$ and ${ }^{3} \mathrm{He} / \mathrm{He}$ Data}

The ${ }^{3} \mathrm{He} / 4 \mathrm{He}$ ratios for both groundwater samples are approximately 5 orders of magnitude above atmospheric levels. In both cases, the ${ }^{3} \mathrm{He}$ is primarily derived from tritium decay, where ${ }^{3} \mathrm{H} \rightarrow{ }^{3} \mathrm{He}+\beta^{-}$. The calculated ${ }^{3} \mathrm{H}-{ }^{3} \mathrm{IIe}$ apparent ages, 21.8 years for water from the upper interval (CH-980728) and 23.7 years for water from the test cavity (CH-980921), reflect ${ }^{3} \mathrm{He}$ in-growth from the decay of bomb produced tritium. These apparent ages correlate well with the 22-year age of the CHESHIRE nuclear test. The ${ }^{4} \mathrm{He}$ concentrations for both samples are approximately an order of magnitude above natural atmospheric levels. Elevated ${ }^{4} \mathrm{He}$ concentrations are derived from the in situ $\alpha$ decay of radioactive elements occurring naturally in the host rock, and indicate a groundwater residence time of up to $\sim 10^{4}$ years.

${ }^{85} \mathrm{Kr},{ }^{14} \mathrm{C},{ }^{36} \mathrm{Cl}$ Data

Dissolved gas samples collected from both the upper and lower perforation levels in U20n PS1 DD-H have high levels of fission-derived ${ }^{85} \mathrm{Kr}$ and exhibit a factor of 2 enrichment with increasing depth. The $1998{ }^{85} \mathrm{Kr}$ concentrations are higher by one to two orders of magnitude than concentrations observed for waters pumped this well in 1983 (Sawyer et al., 1999).

The ${ }^{14} \mathrm{C}$ value of dissolved inorganic carbon from the upper perforation level in U-20n PS 1 DD-H (CH-980728) is more than 900 times greater than that of pre-nuclear testing atmospheric levels, while the sample from the lower perforation level in the cavity $(\mathrm{CH}$ 980921 ) is 1600 times that of atmospheric levels.

\footnotetext{
${ }^{2}$ CH-980921 indicates the CHESHIRE groundwater collected on September 21, 1998.
} 
The ${ }^{36} \mathrm{Cl} / \mathrm{Cl}$ ratio for the upper perforation level (CH-980728) of U-20n PS1 DD-H is a little more than 3 orders of magnitude above environmental levels (where environmental levels are taken to be $-1 \times 10^{-13}$ ). The ratio for the lower perforation level (CH-980921) is approximately 4 orders of magnitude above environmental levels. The increase in ${ }^{36} \mathrm{Cl}$ concentration in the CHESHIRE cavity mimics the same relative increases for ${ }^{3} \mathrm{H},{ }^{14} \mathrm{C}$, and ${ }^{85} \mathrm{Kr}$.

${ }^{87} \mathrm{Sr} r^{86} \mathrm{Sr}$ and U Isotopes Data

The ${ }^{87} \mathrm{Sr} /{ }^{86} \mathrm{Sr}$ ratio in the U-20n PS1 DD-H groundwaters are different between the upper (0.70809) and lower intervals (0.71009). While the $\mathrm{Sr}$ isotope signatures are consistent with natural abundances in the volcanic tuffs at the Nevada Test Site (Peterman et al., 1992), the difference in Sr isotopic signatures in the water is consistent with production from distinct aquifers between the upper and lower sampling intervals. ${ }^{235} \mathrm{U} /{ }^{238} \mathrm{U}$ ratios for groundwaters from both perforation levels in well U-20n PS1 DD-H are comparable, and exhibit natural isotope ratios $(0.007)$. However, the ${ }^{234} \mathrm{U} /{ }^{238} \mathrm{U}$ ratio increases with greater depth, and is similar to the increase observed for the ratio of ${ }^{87} \mathrm{Sr} /{ }^{86} \mathrm{Sr}$.

\section{${ }^{239+240} \mathrm{Pu}$ Data}

Plutonium was detected in water samples collected from the cavity interval only. Samples were analyzed by $\alpha$-spectrometry after the fluid samples had been passed through a 450 $\mathrm{nm}$ filter. Both the filtrate and retentate samples were analyzed. ${ }^{239+240} \mathrm{Pu}$ activity for the material remaining on the filters was $31.0 \mathrm{pCi} / \mathrm{g}$, while the activity in the liquid that passed through the filters was $0.18 \mathrm{pCi} / \mathrm{L}$. The total activity (liquid and solid) for ${ }^{239+240} \mathrm{Pu}$ in the cavity samples was $0.47 \mathrm{pCi} / \mathrm{L}$. However, while the detection of ${ }^{239+240} \mathrm{Pu}$ in the CHESHIRE cavity is not surprising, the concentrations are notable because they are unexpectedly dilute, relative to the quantity of actinide fuels used in a nuclear device (DOE, 1999). Pu was not detected above background $(\sim 0.01 \mathrm{pCi} / \mathrm{L})$ in samples collected from the chimney interval.

\section{Discussion}

The concentration of radionuclides, pumped in 1998 from the upper and lower (cavity) intervals of U-20n PS1 DD-H at the CHESHIRE site, document the ascent of radionuclides from the detonation cavity. The upward distance of this transport is approximately $300 \mathrm{~m}$, and is probably facilitated through communication between an upper and lower aquifer. $\mathrm{Sr}$ and $\mathrm{U}$ isotope ratios in the groundwater suggest these upper and lower production aquifers are geochemically distinct. It is notable that the conservative radionuclides $\left({ }^{3} \mathrm{H},{ }^{14} \mathrm{C},{ }^{36} \mathrm{Cl},{ }^{85} \mathrm{Kr}\right)$ are transported in the same relative abundance between the two perforation intervals. For each, the concentration in the upper interval is approximately half the concentration from the lower, or cavity, interval. This decrease in radionuclide concentration is probably the result of increasing dilution and dispersion of the radionuclides between the cavity and collapse chimney. The concentrations of ${ }^{239+240} \mathrm{Pu}$ in U-20n PS1 DD-H are also comparable to the concentrations 
detected in the ER-20-5 \#1 well. The ER-20-5 \#1 well (adjacent to the TYBO test) was documented to be in hydrologic connection with the BENHAM test, which is located more than 1.3 kilometers up-gradient (Kersting et al., 1999). That the source concentrations in the CHESHIRE cavity are comparable to concentrations more than 1.3 kilometers from the BENHAM test is surprising. Although Kersting et al. (1999) document $\mathrm{Pu}$ migration in the BENHAM-TYBO system, comparison with the CHESHIRE source concentrations may indicate that there is little dilution or attenuation of $\mathrm{Pu}$ as it migrates down-gradient in the groundwater system. It may also suggest that there are differences in release rates for different cavities, which may be controlled by many factors such as lithology, fracture geometry, water chemistry, etc. For these reasons, studies of CHESHIRE cavity water samples are vital to prediction of radionuclide migration on Pahute Mesa.

\section{References}

Department of Energy, Office of Declassification (1999), Drawing Back the Curtain of Secrecy, in: Restricted data declassification decisions 1946 to the present, RDD-5, 127 p.

Isotope Sciences Division (1995), Analytical Measurements: Standard operating procedures for the Underground Test Area. Lawrence Livermore National Laboratory, unpublished report.

Kersting, A.B., Efurd, D.W., Finnegan, D.L., Rokop, D.J., Smith, D.K., and Thompson, J.L. (1999), Migration of plutonium in groundwater at the Nevada Test Site, Nature, v. 397, pp. 56-59.

Peterman, Z.E., Stuckless, J.S., Mahan, S.A., Marshall, B.D., Gutentag, E.D. and Downey, J.S. (1992), Strontium isotope characterization of the Ash Meadows groundwater system, southern Nevada, USA. in: Proceedings of the $7^{\text {th }}$ International symposium on Water-Rock Interaction, 10-18 July 1992, Park City, Utah, A.A. Balkema, Rotterdam (Y.K. Kharaka and A.S. Macst, cds.), pp. 825-829.

Sawyer, D.A., Thompson, J.L., and Smith D.K. (1999), The Cheshire migration experiment: $\Lambda$ summary report. Los Alamos National Laboratory, LA-13555-MS (in preparation).

Smith, D.K. (1998), A recent drilling program to investigate radionuclide migration at the Nevada Test Site, Jour. Radioanalytical and Nuclear Chemistry, v. 235, pp. 159-166.

Smith, D.K., Kersting, A.B., Rose, T.P., Kenneally, J.M., Hudson, G.B., Eaton, G.F. and Davisson, M.L. (1998), Hydrologic Resources Management Program and Underground Test Area Operable Unit FY 1997 Progress Report. Lawrence Livermore National Laboratory, UCRL-ID-130792, 92 p. 
Table I. Analytical results for radionuclides and environmental isotopes from water samples pumped from well U-20n PS1 DD-H. Radionuclides are reported to the time of measure and are not decay corrected.

\begin{tabular}{|c|c|c|}
\hline Sample ID & $\begin{array}{l}\text { CH-980728 } \\
\text { (upper interval) }\end{array}$ & $\begin{array}{l}\text { CH-980921 } \\
\text { (lower interval) }\end{array}$ \\
\hline Sample Date & $7 / 28 / 98$ & $9 / 21 / 98$ \\
\hline $\mathrm{T}\left({ }^{\circ} \mathrm{C}\right)$ & 36.5 & 40.7 \\
\hline $\mathrm{pH}$ & 8.3 & 8.55 \\
\hline Conductivity $(\mu \mathrm{S} / \mathrm{cm})$ & 303 & 317 \\
\hline Dissolved Inorganic Carbon ( $\left.\mathrm{mg} / \mathrm{L} \mathrm{HCO}_{3}\right)$ & 102 & 109 \\
\hline${ }^{85} \mathrm{Kr}(\mathrm{pCi} / \mathrm{L})$ & $1.95 \times 10^{4}$ & $3.39 \times 10^{4}$ \\
\hline${ }^{85} \mathrm{Kr}$ Detection Limit (pCi/L) & $\leq 15$ & $\leq 15$ \\
\hline${ }^{231} \mathrm{U}(\mathrm{pCi} / \mathrm{L})$ & 3.268 & 3.158 \\
\hline${ }^{235} \mathrm{U}(\mathrm{pCi} / \mathrm{L})$ & 0.049 & 0.036 \\
\hline${ }^{238} \mathrm{U}(\mathrm{pCi} / \mathrm{L})$ & 1.035 & 0.768 \\
\hline${ }^{36} \mathrm{Cl}(\mathrm{pCi} / \mathrm{L})$ & $2.462 \times 10^{-1}$ & $4.966 \times 10^{-1}$ \\
\hline${ }^{3} \mathrm{H}$ (field measurement in $\mathrm{pCi} / \mathrm{L}$ ) & $3.9 \times 10^{7}$ & $7.0 \times 10^{7}$ \\
\hline${ }^{3} \mathrm{He} /{ }^{4} \mathrm{He}$ (measured) & 0.1285 & 0.2168 \\
\hline${ }^{3} \mathrm{He} /{ }^{4} \mathrm{He}$ (relative to ${ }^{3} \mathrm{He} /{ }^{4} \mathrm{He}$ in air) & $9.3 \times 10^{4}$ & $1.6 \times 10^{5}$ \\
\hline${ }^{4} \mathrm{He}($ atoms $/ \mathrm{mL})$ & $1.50 \times 10^{13}$ & $1.85 \times 10^{13}$ \\
\hline${ }^{3} \mathrm{H}-{ }^{3} \mathrm{He}$ apparent age (years) & 21.8 & 23.7 \\
\hline$\delta \mathrm{D}$ (\%o relative to SMOW standard) & -113 & -113 \\
\hline$\delta^{18} \mathrm{O}$ (\%o relative to SMOW standard) & -14.9 & -14.9 \\
\hline$\delta^{13} \mathrm{C}(\%$ relative to PDB standard $)$ & -5.9 & -5.7 \\
\hline${ }^{14} \mathrm{C}$ (percent modern carbon) & 91,431 & 160,450 \\
\hline${ }^{14} \mathrm{C}$ error $(\%)$ & $\leq 5$ & $\leq 5$ \\
\hline${ }^{36} \mathrm{Cl} / \mathrm{Cl}$ & $6.43 \times 10^{-10}$ & $1.09 \times 10^{-9}$ \\
\hline$[\mathrm{Cl}](\mathrm{mg} / \mathrm{L})$ & 11.6 & 13.8 \\
\hline${ }^{36} \mathrm{Cl}$ (atoms/L) & $1.25 \times 10^{11}$ & $2.52 \times 10^{11}$ \\
\hline${ }^{239+240} \mathrm{Pu}$ (liquid) (pCi/L) & $<0.0044$ & 0.176 \\
\hline${ }^{239+240} \mathrm{Pu}$ (solid) (pCi/g) & $<1.79$ & 31.0 \\
\hline${ }^{239+240} \mathrm{Pu}($ total $)(\mathrm{pCi} / \mathrm{L})$ & $<0.0069$ & 0.468 \\
\hline${ }^{87} \mathrm{Sr} /{ }^{86} \mathrm{Sr}$ & $0.70809 \pm 0.00003$ & $0.71009 \pm 0.0002$ \\
\hline$\delta^{87} \mathrm{Sr}(\% 0)$ & -1.57 & 1.25 \\
\hline${ }^{234} \mathrm{U} /{ }^{238} \mathrm{U}$ & 0.000171 & 0.000223 \\
\hline${ }^{234} \mathrm{U} /{ }^{235} \mathrm{U}$ & 0.02332 & 0.03069 \\
\hline${ }^{235} \mathrm{U} /{ }^{238} \mathrm{U}$ & 0.007332 & 0.007256 \\
\hline${ }^{234} \mathrm{U} /{ }^{238} \mathrm{U}$ activity ratio & 3.1248 & 4.0701 \\
\hline
\end{tabular}




\title{
- Chapter 2 -
}

\section{FY 1998 Re-entry, Re-conditioning, and Sample Analyses at CAMEMBERT (U19q-PS1 D)}

\author{
Isotopic Tracers and Transport Team
}

\section{Introduction}

In FY 1997 the Desert Research Institute, Los Alamos National Laboratory, BechtelNevada, and the U.S. Department of Energy, Nevada Operations Office evaluated the available post-shot holes on Pahute Mesa for potential re-completion. After identifying wells suitable for re-completion, the well sites were then evaluated to determine which wells might provide access to saturated nuclear test cavities, and which might be best suited for conversion to observation well status. As a result of this evaluation, the postshot hole for the CAMEMBERT test (U-19q PS1 D) was selected for re-completion in October of 1998. Rehabilitation of the existing hole was expected to access the test cavity at a depth interval of 4600 to $4700 \mathrm{ft}$ (1400 to $1432 \mathrm{~m})$.

The CAMEMBERT test was detonated in emplacement hole U-19q on 26 June 1975 , at a depth of $4301 \mathrm{ft}(1311 \mathrm{~m})$ beneath Pahute Mesa in Area 19 of the Nevada Test Site. The announced total nuclear yield was between 200 - 1000 kilotons, and the depth from ground surface to the pre-shot standing water level was $2191 \mathrm{ft}(668 \mathrm{~m})$. In August of 1975, the post shot re-entry hole U-19q PS1 D was drilled to a total slant depth of $4991 \mathrm{ft}$ $(1521 \mathrm{~m})$ in rhyolitic volcanic rock. This post-shot hole was slant drilled at a $22^{\circ}$ angle, and the wellhead is located approximately $1199 \mathrm{ft}(366 \mathrm{~m})$ northeast of surface ground zero for the CAMEMBERT test. In 1975 , a $9 \frac{5}{8}$ inch liner was emplaced to a total depth of $3665 \mathrm{ft}(1117 \mathrm{~m})$ below an existing $13 \frac{3}{8}$ inch casing.

Beginning in October of 1998, a drill rig was erected over U19q PS1 D and the hole was re-entered. Immediately below the liner in the open hole, an obstruction (fill) was encountered at a depth of $3690 \mathrm{ft}(1125 \mathrm{~m})$ and the well was recompleted only to this depth. A submersible pump was then set at a depth of approximately $3000 \mathrm{ft}(916 \mathrm{~m})$. After purging the well (total purge volume was 12,455 gallons) samples were collected on both 20 October and 21 October 1998. Since well U19q PS1 D was not sampled following the initial drillback in 1975 , historical bascline data pertaining to radionuclide concentrations is lacking. It should be noted that there was some difficulty encountered during pumping caused by large amounts of sediment in the hole. Since the amount of sediment in the well water appeared to be decreasing, only samples collected on the second day of pumping were analyzed. Tritium concentrations were initially variable, but 
stabilized on the second day (Fig. 1). The tritium activity for CM-981021 ${ }^{1}$, measured in the field during sampling on 21 October, was $2.1 \times 10^{7} \mathrm{pCi} / \mathrm{L}$.

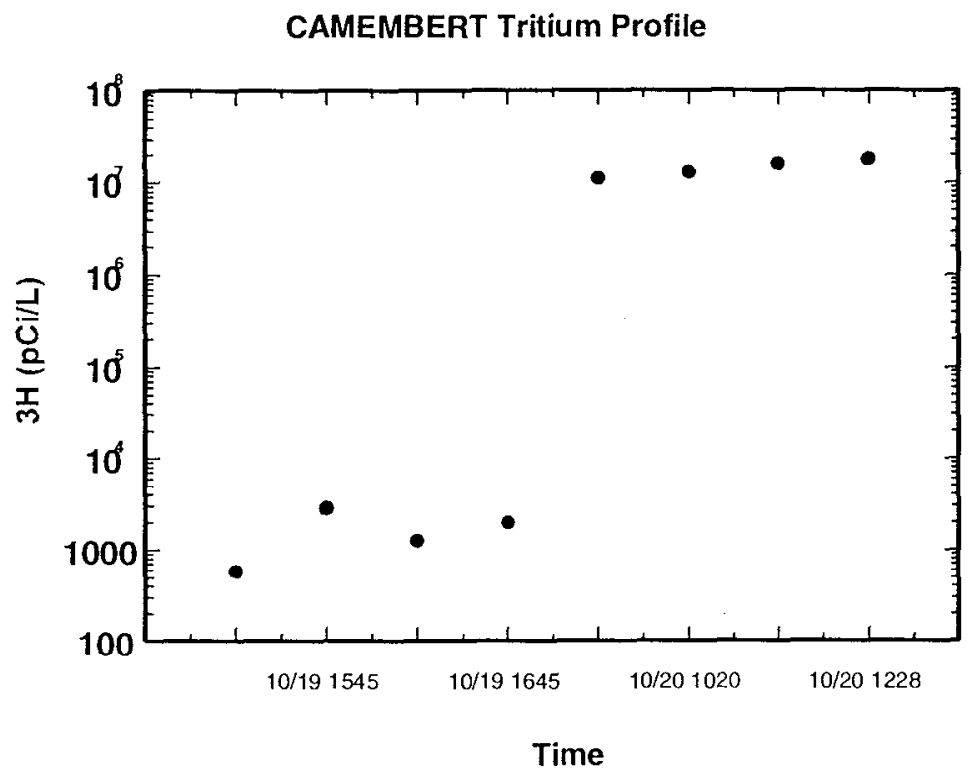

Figure 1: Graph of ${ }^{3} \mathrm{H}$ vs. time for CAMEMBERT well water. The $\mathrm{x}$-axis shows the date and time of collection for each sample.

\section{Analytical Results}

Analytical results are tabulated with uncertainties and detection limits in Table 1. Laboratory analytical protocols are found in standard operating procedures written in support of the UGTA Program (ISD, 1995). Radionuclide data in this chapter are reported relative to the time of measurement in 1998, and are not decay corrected. References for observed concentrations of radionuclides in groundwater at the Nevada Test Site are found in Borg et al. (1976), and Buddemeier et al. (1991). Recent compilations of hot well data are given elsewhere in this report, and Daniels (1993).

\section{${ }^{3} \mathrm{H}{ }^{3} \mathrm{He}$ and ${ }^{3} \mathrm{He} /{ }^{4} \mathrm{He}$ Data}

The ${ }^{3} \mathrm{He} /{ }^{4} \mathrm{He}$ ratio for $\mathrm{CM}-981021$ is almost 4 orders of magnitude above atmospheric levels. Normally, the ${ }^{3} \mathrm{He}$ is assumed to be derived primarily from tritium decay, where ${ }^{3} \mathrm{H} \rightarrow{ }^{3} \mathrm{He}+\beta^{-}$. However, the calculated ${ }^{3} \mathrm{H}-{ }^{3} \mathrm{He}$ apparent age of 30.9 years for $\mathrm{CM}-$ 981021 over estimates the actual age of the CAMEMBERT test by 8 years. Although this age difference is within the $3 \sigma$ error for the analytical method, the discrepancy probably reflects inaccuracies in the tritium measurement, which was determined in the

\footnotetext{
'For data security purposes, a LLNL sample identification system has been instituted. CM-981021 indicates the CAMEMBERT groundwater sample collected on October 21, 1998.
} 
field by liquid scintillation counting. The age discrepancy may also be explained by the presence of excess helium in the system.

The ${ }^{4} \mathrm{He}$ concentration for CM-981021 is approximately 2 orders of magnitude above natural atmospheric levels, and is the highest ${ }^{4} \mathrm{He}$ value observed on Pahute Mesa thus far. There are two potential explanations for this result. One possibility is that the excess ${ }^{4} \mathrm{He}$ was generated during weapons testing. However, groundwater samples collected from other ncar-field wells on Pahutc Mcsa do not exhibit such high lcvels of ${ }^{4} \mathrm{Hc}$ (sce Table 2). It is also noteworthy that the ${ }^{4} \mathrm{He}$ concentration of the fluid sample collected from the CHESHIRE cavity was not elevated with respect to other Pahute Mesa samples. Alternatively, the excess ${ }^{4} \mathrm{He}$ may be produced by in situ $\alpha$-decay of the radioactive elements that occur naturally in the host rock. Several groundwater samples collected down gradient from Pahute Mesa (Oasis Valley area) have ${ }^{4} \mathrm{He}$ concentrations comparable to that of to the CM-981021 (Table 2). High ${ }^{4} \mathrm{He}$ concentrations are also observed in groundwater from Emigrant Valley and northern Yucca Flat. None of these comparative samples are associated with weapons testing. These high concentrations likely indicate an association with deep crustal rocks, where ${ }^{4} \mathrm{He}$ levels may be higher due to the age of these rocks.

${ }^{85} \mathrm{Kr},{ }^{14} \mathrm{C},{ }^{36} \mathrm{Cl}$ Data

In addition to having clevated ${ }^{3} \mathrm{Hc}$ and ${ }^{4} \mathrm{He}$ concentrations, the U19q PS1 D has one of the highest levels of fission-derived ${ }^{85} \mathrm{Kr}$ observed in any of the UGTA wells sampled thus far. Only groundwater samples from U-3cn PS2 (BILBY), collected in January of 1997, show higher levels of ${ }^{85} \mathrm{Kr}$ (ISD, 1997). The ${ }^{14} \mathrm{C}$ value of dissolved inorganic carbon (DIC) from U19q PS1 D (CM-981021) is more than 3 orders of magnitude greater than the pre-nuclear testing atmospheric levels, making it one of the highest ${ }^{14} \mathrm{C}$ activities thus far observed in the near-field environment. However, the ${ }^{36} \mathrm{Cl} / \mathrm{Cl}$ ratio for $\mathrm{U} 19 \mathrm{q}$ PS1 $\mathrm{D}$ (CM-981021) is only $\sim 2$ orders of magnitude above environmental levels (where environmental levels are taken to be $\sim 1 \times 10^{-13}$ ). The relatively low ${ }^{36} \mathrm{Cl} / \mathrm{Cl}$ ratio, in comparison to enrichments in the other volatile radionuclides, may be due to the physical separation of gases from dissolved anionic species higher in the collapse chimney. The movement of gaseous radionuclides has been documented in other test cavities (BechtelNevada, 1996; Smith, 1998).

${ }^{87} \mathrm{Sr}{ }^{86} \mathrm{Sr}$ and U Data

The ${ }^{87} \mathrm{Sr} /{ }^{86} \mathrm{Sr}$ ratio from the U19q PS1 D groundwaters is within the accepted range for the natural abundances of $\mathrm{Sr}$ in volcanic tuffs at the Nevada Test Site (Peterman et al., 1992). The uranium concentrations from U19q PS1 D (CM-981021) are low (i.e., at the detection limit), although similarly low uranium concentrations have been previously observed in other monitoring wells in southern Nevada (Smith et al., 1998). The ${ }^{235} \mathrm{U} /{ }^{238} \mathrm{U}$ ratio of groundwaters from well U19q PS 1 D are also within the accepted range for natural abundances of uranium $(0.007)$. The ${ }^{234} \mathrm{U} /{ }^{238} \mathrm{U}$ activity ratio is enriched relative to secular equilibrium, and reflects the preferential leaching of ${ }^{234} \mathrm{U}$ from 
uranium-bearing minerals in the aquifer matrix, following $\alpha$-decay of ${ }^{238} \mathrm{U}$. These results are in keeping with other non-secular ratios observed for Nevada Test Site groundwaters.

\section{${ }^{239+240} \mathrm{Pu}$ Data}

Plutonium $(\mathrm{Pu})$ was detected in the groundwater water collected from the vicinity of U19q PS1 D. Samples were analyzed using $\alpha$-spectrometry after the fluid samples had been passed through a $450 \mathrm{~nm}$ filter. Both the filtrate and retentate samples were analyzed. ${ }^{239+240} \mathrm{Pu}$ activity for the material remaining on the filters was $0.08 \mathrm{pCi} / \mathrm{g}$, while the activity in the liquid that passed through the filters was less that the minimum

detectable concentration. The total activity (liquid and solid) for ${ }^{239+240} \mathrm{Pu}$ in the cavity samples was $0.02 \mathrm{pCi} / \mathrm{L}$. Like DALHART (U-4u) and CHESHIRE (U-20n) this is another example of the detection of $\mathrm{Pu}$ in the chimney environment (Smith et al., 1998), and in this case more than 600 feet $(190 \mathrm{~m}$ ) above the working (firing) point of the test. A majority of the $\mathrm{Pu}$ occurs as a filterable solid phase implying that $\mathrm{Pu}$ is primarily associated with colloidal or particulate matter (Kersting et al., 1999).

\section{Discussion}

\section{Gas Chemistry and $\delta^{13} \mathrm{C}$ of Formation Waters}

The level of DIC from U19q PS1 D is approximately 6 times greater than natural concentrations in Pahute Mesa groundwater. This result is significant considering that the well is developed in volcanic rocks, making a geologic source for the elevated DIC concentrations unlikely. Moreover, the $\delta^{13} \mathrm{C}$ value of the groundwater $(+1.5 \%$ ) is enriched in ${ }^{13} \mathrm{C}$ relative to all groundwater samples collected from the Nevada Test Site prior to 1998. These results suggest a closed, or partially-closed system, with respect to carbon isotopic exchange. One process known to generate isotopically enriched $\delta^{13} \mathrm{C}$ values is the bacteriologically-mediated breakdown of organic matter. In oxygendepleted environments, methanogenic bacteria will ferment organic matter to produce $\mathrm{CO}_{2}$ and $\mathrm{CH}_{4}$ gases (e.g., Carothers and Kharaka, 1980). Isotopic fractionation of ${ }^{12} \mathrm{C}$ into $\mathrm{CH}_{4}$ during this process causes the co-existing $\mathrm{CO}_{2}$ to become highly enriched in ${ }^{13} \mathrm{C}$ (Bottinga, 1969). Evidence for this process is provided by a chemical analysis of gas taken from the U19q PS1 D well bore prior to groundwater pumping (see Table 3). The gas shows a significant depletion in oxygen $\left(0.1 \% \mathrm{O}_{2}\right)$ relative to atmospheric levels $\left(21 \% \mathrm{O}_{2}\right)$, and an abundance of hydrogen gas $(>8 \%)$, indicating anoxic, reducing conditions favorable to methanogenesis. The gas also contains $1 \%$ methane, but essentially no $\mathrm{CO}_{2}$ gas. This absence of $\mathrm{CO}_{2}$ in the gas phase accounts for the high concentration of dissolved carbon in the groundwater, and the presence of methane gas accounts for the isotopically enriched $\delta^{13} \mathrm{C}$ value of the DIC. The $\mathrm{pH}$ value for the groundwater (7.2) is also consistent with the presence of dissolved $\mathrm{CO}_{2}$. The remainder of the gas resembles oxygen-depleted air.

Perhaps the most remarkable aspect of these results is the indication of a closed or partially closed system, which isolates the cavity-chimney from exchange with the natural environment. Even if the system is only partially closed, the unusual enrichments 
in DIC and $\delta^{13} \mathrm{C}$ following a substantial purge volume indicate that the sampled portion of the system does not have a high turnover rate. This implies that the test cavitychimney system is not in open communication with the regional groundwater flow system. Equally remarkable is the fact that these conditions have persisted for $>23$ years--since the time of the CAMEMBERT detonation.

\section{Similarities to Other Pahute Mesa Wells}

It should be noted that the apparently semi-closed system at U-19q (CAMEMBERT) is not a unique occurrence. Like U-19q, well U-19v (ALEMANDRO) is also completed in a post-shot re-entry hole (see the discussion of hot well sampling in chapter 3 of this report). Both tests were conducted in central Pahute Mesa with U-19v being situated approximately 2 miles (3.2 kilometers) south of U-19q. A bailed groundwater sample collected from well U-19v on September 23, 1998 was found to have a dramatically enriched $\delta^{13} \mathrm{C}$ value of $+27 \%$. Although the DIC concentration $(280 \mathrm{mg} / \mathrm{L})$ is not as high as for waters collected from U-19q PS1 D, it is still more than double that observed normally in Pahute Mesa groundwaters. Other indications of closed system processes at $\mathrm{U}-19 \mathrm{v}$ include significantly elevated water temperatures, and an isotopically shifted groundwater $\delta^{18} \mathrm{O}$ value that reveals closed system fluid-rock interaction. Since the existence of semi-closed nuclear test cavity environments has important implications for migration of radionuclides at the Nevada Test Site, significant issues that should be pursued in regard to these observations include: 1) determination of how many other tests are environmentally isolated from the regional groundwater flow system, and 2) understanding the controls on this closed system behavior.

\section{References}

Analytical and Nuclear Chemistry Division, (1999), Isotopic Analyses: Re-entry Well U19q-PS\#1d, Lawrence Livermore National Laboratory, unpublished letter report.

Bechtel-Nevada (1996), Hydrogeologic characterization of the U-3bh collapse zone, 10 pp with appendices.

Borg, I.Y., Stone, R., Levy, H.B. and Ramspott, L.D. (1976), Information pertinent to the migration of radionuclides in ground water at the Nevada Test Site. Lawrence Livermore National Laboratory, UCRL-5278, $216 \mathrm{p}$.

Bottinga, Y. (1968), Isotopic fractionation in the system, Calcite-graphite-carbon dioxide-methanehydrogen-water: University of California at San Diego, Ph. D. thesis, 126 p.

Buddemeier, R.W., Finkel, R.C., Marsh, K.V., Ruggieri, M.R., Rego, J.H. and Silva, R.J. (1991), Hydrology and radionuclide migration at the Nevada Test Site. Radiochimica Acta, vol. 52/53, pp. 275-282.

Carothers, W. W., and Kharaka, Y. K. (1980), Stable carbon isotopes of $\mathrm{HCO}_{3}^{-}$in oil-field waters--implications for the origin of $\mathrm{CO}_{2}$. Geochim. et Cosmochim. Acta, vol. 44, pp. 323-332.

Daniels, I. ed. (1993), Pilot study risk assessment for selected problems at the Nevada Test Site (NTS) Lawrence Livermore National Laboratory, UCRL-LR-113891, 108 p. 
Isotope Sciences Division (1998a), Isulopic Analyses: Monitoring Well ER-20-5. Lawrence Livermore National Laboratory, unpublished letter report.

Isotope Sciences Division (1998b), Isotopic Analyses: Monitoring Well ER-20-6. Lawrence Livermore National Laboratory, unpublished letter report.

Isotope Sciences Division (1997), Final Isotopic Analyses: Monitoring Well U-3cn. I awrence Livermore National Laboratory, unpublished letter report.

Isotope Sciences Division (1995), Analytical Measurements: Standard operating procedures for the underground test area. Lawrence Livermore National Laboratory, unpublished letter report.

Peterman, Z.E., Stuckless, J.S., Mahan, S.A., Marshall, B.D., Gutentag, E.D., and Downey, J.S. (1992), Strontium isotope characterization of the Ash Meadows groundwater system, southern Nevada, USA In: Y.K. Kharaka and A.S. Maest, eds., Proceedings of the $7^{\text {th }}$ International symposium on Water-Rock Interaction, 10-18 July 1992, Park City, Utah. A.A. Balkema, Rotterdam, pp. 825-829.

Rose, T.P., Kenneally, J.M., Smith, D.K., Davisson, M.L., Hudson, G.B., Rego, J. (1997), Chemical and Isotopic Data for Groundwater in Southern Nevada, UCRL-ID-128000, 38 p.

Smith, D.K., Kersting, A.B., Rose, T.P., Kenneally, J.M., Hudson, G.B., Eaton, G.F. and Davisson, M.L. (1998), Hydrologic Resources Management Program and Underground Test Area Operable Unit FY 1997 Progress Report. Lawrence Livermore National Laboratory, UCRL-ID-130792, 92 p.

Smith, D.K. (1998), A recent drilling program to investigate radionuclide migration at the Nevada Test Site, Jour. Radioanalytical and Nuclear Chemistry, v. 235, pp. 159-166.

Thomas, J.M., Benedict, F.C., Jr., Rose, T.P., Hershey, R.L., Paces, J.B., Peterman, Z.E, Farnham, I.M., Zahniser, W.J., Singh, A.K., Stetzenbach, K.J., Hudson, G.B., Kenneally, J.M., Eaton,G.F., and Smith, D.K. (1999), Geochemical and isotopic data from the Oasis Valley groundwater flow system, southern Nevada. Data report submitted to DOE/NVOO, UGTA Program, for publication, $97 \mathrm{p}$. 
Table 1. Analytical results for radionuclides and environmental isotopes from water samples pumped from well U-19q PSI D (ANCD, 1999). Radionuclides are reported to the time of measure and are not decay corrected.

\begin{tabular}{|c|c|}
\hline Sample ID & CM-981021 \\
\hline Sample Date & $10 / 21 / 98$ \\
\hline $\mathrm{T}\left({ }^{\circ} \mathrm{C}\right)$ & 33.0 \\
\hline $\mathrm{pH}$ & 7.21 \\
\hline Conductivity $(\mu \mathrm{S} / \mathrm{cm})$ & 959 \\
\hline Dissolved Inorganic Carbon $\left(\mathrm{mg} / \mathrm{L} \mathrm{HCO}_{3}\right)$ & 1016 \\
\hline${ }^{85} \mathrm{Kr}(\mathrm{pCi} / \mathrm{L})$ & $1.1 \times 10^{5}$ \\
\hline${ }^{85} \mathrm{Kr}$ Detection Limit $(\mathrm{pCi} / \mathrm{L})$ & $\leq 15$ \\
\hline${ }^{234} \mathrm{U}(\mathrm{pCl} / \mathrm{L})$ & $<0.509$ \\
\hline${ }^{235} \mathrm{U}(\mathrm{pCi} / \mathrm{L})$ & $<0.008$ \\
\hline${ }^{238} \mathrm{U}(\mathrm{pCi} / \mathrm{L})$ & $<0.167$ \\
\hline${ }^{36} \mathrm{Cl}(\mathrm{pCi} / \mathrm{L})$ & $1.813 \times 10^{-2}$ \\
\hline${ }^{239+240} \mathrm{Pu}$ (liquid) (pCi/L) & $<0.00604$ \\
\hline${ }^{239+240} \mathrm{Pu}$ (solid) (pCi/g) & 0.0804 \\
\hline${ }^{239+210} \mathrm{Pu}($ total $)(\mathrm{pCi} / \mathrm{L})$ & 0.0245 \\
\hline${ }^{3} \mathrm{H}$ (field measurement in pCi/L) & $2.1 \times 10^{7}$ \\
\hline${ }^{3} \mathrm{He} /{ }^{4} \mathrm{He}$ (measured) & 0.0109 \\
\hline${ }^{3} \mathrm{He} /{ }^{4} \mathrm{He}$ (relative to ${ }^{3} \mathrm{He} /{ }^{4} \mathrm{He}$ in air) & $7.9 \times 10^{3}$ \\
\hline${ }^{4} \mathrm{He}($ atoms $/ \mathrm{mL}$ ) & $1.85 \times 10^{14}$ \\
\hline${ }^{3} \mathrm{H}-{ }^{3} \mathrm{He}$ apparent age (years) & $30.9 \pm 10 \%$ \\
\hline$\delta \mathrm{D}$ (\%o relative to SMOW standard) & -112 \\
\hline$\delta^{18} \mathrm{O}(\%$ o relative to SMOW standard) & -14.6 \\
\hline$\delta^{13} \mathrm{C}$ (\%o relative to PDB) & +1.5 \\
\hline${ }^{14} \mathrm{C}$ (percent modern carbon) & 107,004 \\
\hline${ }^{14} \mathrm{C}$ error (\%) & $\leq 5$ \\
\hline${ }^{36} \mathrm{Cl} / \mathrm{Cl}$ & $5.28 \times 10^{-11}$ \\
\hline$[\mathrm{Cl}](\mathrm{mg} / \mathrm{L})$ & 10.4 \\
\hline${ }^{36} \mathrm{Cl}($ atoms $/ \mathrm{L})$ & $9.19 \times 10^{9}$ \\
\hline${ }^{87} \mathrm{Sr} /{ }^{86} \mathrm{Sr}$ & $0.7126 \pm 0.0064$ \\
\hline$\delta^{87} \mathrm{Sr}(\%)$ & 4.79 \\
\hline${ }^{234} \mathrm{U} /{ }^{238} \mathrm{U}$ & $0.000165 \pm 0.000002$ \\
\hline${ }^{234} \mathrm{U} /{ }^{235} \mathrm{U}$ & $0.02245=-$ \\
\hline${ }^{235} \mathrm{U} f^{238} \mathrm{U}$ & $0.00735 \pm 0.00010$ \\
\hline${ }^{234} \mathrm{U}{ }^{238} \mathrm{U}$ activity ratio & 3.0154 \\
\hline
\end{tabular}


Table 2: Table comparing ${ }^{4} \mathrm{He}$ concentrations of Pahute Mesa Wells with wells lying both down gradient, and to the east of the Mesa.

\begin{tabular}{|c|c|c|}
\hline Well & Collection Date & ${ }^{4} \mathrm{He}$ (atoms/mL) \\
\hline \multicolumn{3}{|l|}{ Camcmbert (Pahute Mesa) } \\
\hline U-19q PS1 D & $10 / 21 / 98$ & $1.85 \times 10^{14}$ \\
\hline \multicolumn{3}{|l|}{ Other Pahute Mesa Wells } \\
\hline U-20n PS1 DD H (upper) & $7 / 28 / 98$ & $1.50 \times 10^{13}$ \\
\hline U-20n PS1 DD H (lower) & $9 / 21 / 98$ & $1.85 \times 10^{13}$ \\
\hline ER-20-5 $\# 1^{2}$ & $7 / 9 / 98$ & $2.64 \times 10^{13}$ \\
\hline ER-20-5 \#3 & $4 / 30 / 98$ & $2.08 \times 10^{13}$ \\
\hline ER-20-6 $\# 1^{3}$ & $5 / 15 / 98$ & $5.06 \times 10^{12}$ \\
\hline ER-20-6 $\# 3^{3}$ & $5 / 14 / 98$ & $5.41 \times 10^{12}$ \\
\hline \multicolumn{3}{|l|}{ Oasis Valley Wells \& Springs } \\
\hline Bailey Hot Spring ${ }^{4}$ & $11 / 14 / 97$ & $1.30 \times 10^{14}$ \\
\hline Coffers Windmill ${ }^{4}$ & $11 / 11 / 97$ & $1.60 \times 10^{14}$ \\
\hline ER-OV-6a ${ }^{4}$ & $11 / 18 / 97$ & $1.20 \times 10^{14}$ \\
\hline ER-OV-1 ${ }^{4}$ & $11 / 18 / 97$ & $1.20 \times 10^{14}$ \\
\hline \multicolumn{3}{|c|}{ Yucca Flat/Emigrant Valley Wells } \\
\hline UE-10j (lower interval) ${ }^{5}$ & $3 / 17 / 97$ & $1.20 \times 10^{14}$ \\
\hline Watertown Well $\# 4^{5}$ & $8 / 15 / 95$ & $2.30 \times 10^{14}$ \\
\hline
\end{tabular}

T(ANCD, 1999); ${ }^{2}$ (ISD, 1999a); ${ }^{3}$ (ISD, 1999b); ${ }^{4}$ (Thomas et al., 1999); ${ }^{3}$ (Rose et al., 1997)

Table 3: Analytical results for gas sampled from the U19q PS1 D well bore prior to groundwater pumping.

\begin{tabular}{|c|c|c|}
\hline Component & $\begin{array}{l}\text { U19q PS1 D Gas } \\
\text { Concentration } \\
\text { (\% by volume })\end{array}$ & $\begin{array}{c}\text { Normal Atmospheric } \\
\text { Concentration } \\
(\% \text { by volume })\end{array}$ \\
\hline Nitrogen & $89.54 \pm 0.06$ & $78.08 \pm 0.004$ \\
\hline Oxygen & $0.12 \pm 0.01$ & $20.95 \pm 0.002$ \\
\hline Argon & $1.07 \pm 0.01$ & $0.93 \pm 0.001$ \\
\hline Carbon Dioxide $\mathrm{CO}_{2}$ & $<0.01 \pm 0.01$ & $0.03 \pm 0.001$ \\
\hline Methane $\quad \mathrm{CH}_{4}$ & $0.99 \pm 0.01$ & trace \\
\hline Hydrogen & $8.28 \pm 0.01$ & trace \\
\hline
\end{tabular}




\title{
-Chapter 3-
}

\section{FY 1998 Hot Well Report}

\author{
Jacqueline M. Kenneally
}

\section{Introduction}

Underground nuclear weapons testing by the United States Department of Energy (DOE) and predecessor agencies deposited a significant radiologic source term of $>10^{8} \mathrm{Ci}$ beneath the Nevada Test Site (NTS) (Goishi et al., 1994). Tests were conducted both above and below the water table in a variety of geologic media (alluvium, volcanic and carbonate rocks). A portion of the radiologic source term is incorporated into groundwater as a hydrologic source term raising concerns that radionuclides may be transported beyond the boundaries of the NTS. The hydrologic source term is defined here as radionuclides dissolved or mechanically transportable in groundwater. The composition and controls on the concentration and speciation of radionuclides in the hydrologic source term remain poorly understood. The purpose of this work is to gain a better understanding of the composition and evolution of the hydrologic source term.

Few post-shot holes associated with the more than 800 underground tests remain viable wells for cavity fluid sampling. Of the wells that penetrate the water table, many were filled with cement following radiochemical sampling, others have collapsed, are inaccessible due to mechanical obstructions, or no longer extend to the cavity region. Despite the small number of useful wells, fluid samples have been collected over multiple years from several wells that contain fluid impacted by underground testing (Smith et al., 1998).

Bailing and pumping are the primary methods of groundwater sampling at the NTS. In recent years, most samples collected for this project have been collected via bailing (see Smith et al., 1998). Sample collection using bailing techniques may not be an ideal mechanism to sample post-shot wells because the small volumes of fluid extracted from the well bore do not adequately purge the system. Although this technique allows collection of small volume fluid samples, pumping to collect more representative samples may provide better data and subsequently allow a much-improved understanding of the hydrologic source term.

Hot well samples were collected at three different sites during FY-98 by a multidisciplinary team from the United States Geological Survey (USGS), Bechtel-Nevada (BN), Los Alamos National Laboratory (LANL), and Lawrence Livermore National Laboratory (LLNL) during September of 1998 using discrete interval tandem bailing equipment and a tandem Bennett pump system. Bailed samples were collected from well 


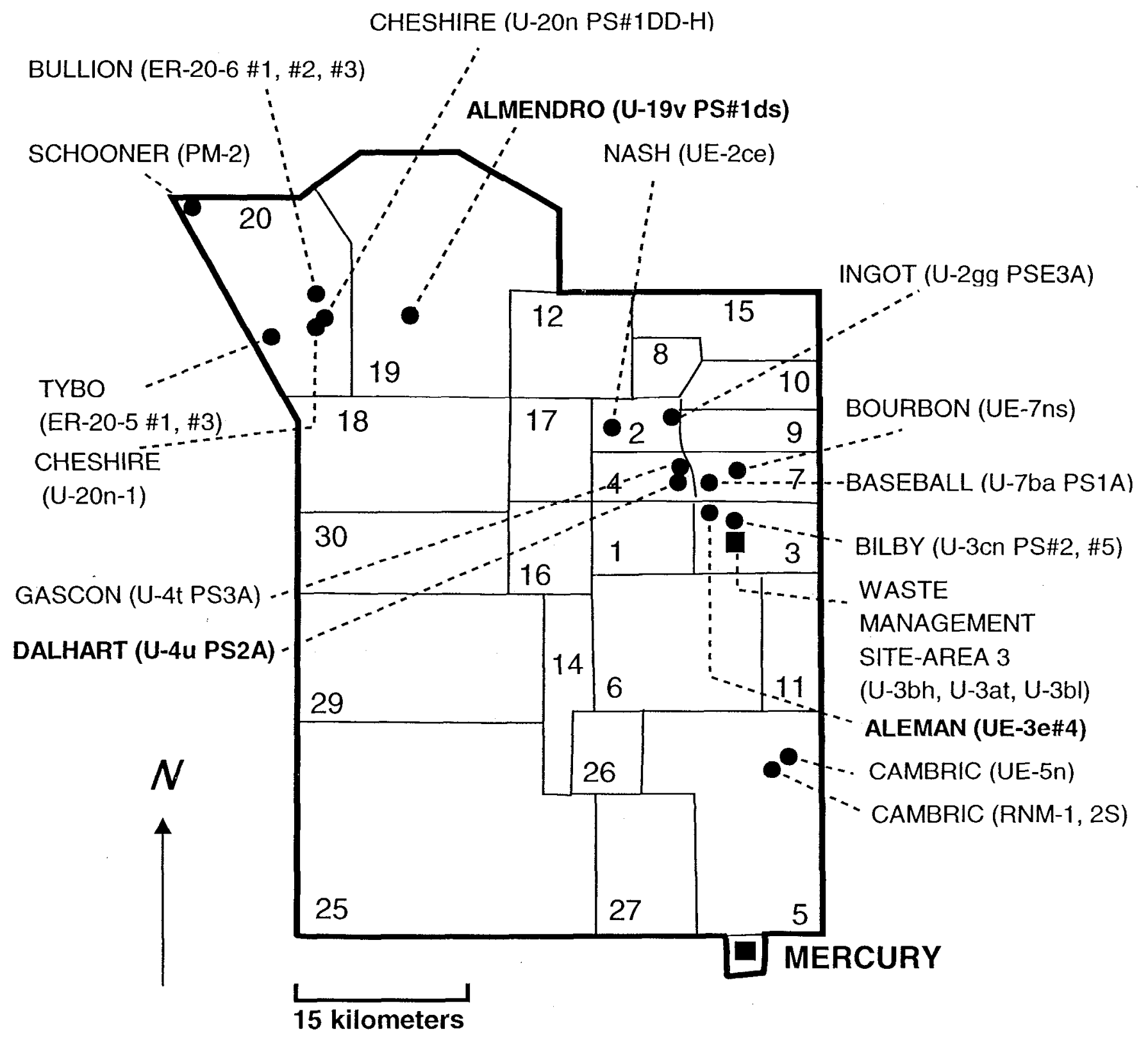

Figure 1: Location map showing the cavity or near cavity ("hot") drill-holes and wells studied by the Hydrologic Resources Management Program and Underground Test Area Operable Unit at the Nevada Test Site. Highlighted wells were sampled in FY1998 
U19vPS1ds (the ALMENDRO post-shot well), and the UE3e\#4 piezometer cluster (a well adjacent to and historically associated with the ALEMAN test). Pumped samples were collected from U4uPS2a (the DALHART post-shot well). See Figure 1.

To assist in the collection of more representative cavity fluid samples, BN personnel successfully deployed a set of tandem Bennett pumps. The tandem arrangement of the Bennett pumps had not been deployed at the NTS prior to this field trial. The pumps were attached in a unique tandem geometry that allowed fluid to be pumped from a depth much greater than 244 meters, the approximate lifting capacity of a single pump. This ability allows for the cost-effective pumping of fluids from post-shot holes, and shows promise in facilitating the collection of more representative cavity fluid samples. Analytical results from FY1998 hot well sampling are presented in Tables 1-3 with radionuclide activities tabulated at time of collection, and decay-corrected to 1/1/94 for comparative purposes. Measurements of $\mathrm{pH}$, temperature, and conductivity were not conducted in the field; however, laboratory measurements for $\mathrm{pH}$ and conductivity are presented in Table 1 .

\section{Well UE3e \#4}

A general summary of the hole history and conditions are presented here. The reader is referred to Thompson (1991) for a more thorough review of the justification and operational details of this project. Well UE3e\#4 was drilled in 1990 as the fourth well drilled in an attempt to better understand unexpected radionuclide migration into the unexpended U3kz (ALEMAN) emplacement hole. The three wells drilled before UE3e\#4 are no longer available for sampling.

Well UE3e\#4 was drilled approximately 58 meters north of U3kz. In addition to the nearby ALEMAN test, surface expressions of four events lie within approximately $0.5 \mathrm{~km}$ of well UE3e\#4. As a result of nearby testing, radionuclides were detected in two discrete zones during drilling of well UE3e\#4. The radionuclides are interpreted to originate from the SANDREEF test approximately 350 meters from U3kz (Thompson et al., 1991).

UE3e\#4 was completed with three separate piezometer tubes at the following intervals: UE3e\#4 Piezometer \#1 (UE3e\#4 P-1) is screencd at a depth of 655.3 to $661.7 \mathrm{mbs,}$ UE3e\#4 Piezometer \#2 (UE3e\#4 P-2) is screened at a depth of 575.2 to $581.6 \mathrm{mbs}$, and UE3e\#4 Piezometer \#3 (UE3e\#4 P-3) is screened at a depth of 493.5 to 499.9 mbs.

Following completion, the three piezometers were swabbed and fluid was bailed from the tubes in an attempt to clean the drilling and completion fluids from the piezometer tubes. The attempted cleaning of the piezometers probably helped but did not completely remove all of the contaminants. Groundwater quality parameters such as $\mathrm{pH}$ and conductivity remained abnormally high and partially reacted cement particulate was found in samples collected from the tubes (Thompson et al., 1991). 


\section{Well UE3e \#4 Piezometer \#1}

On September 23, 1998 a sample was collected from $658 \mathrm{mbs}$, which is within the screened interval. Analytical results are presented in Tables 1-3. The fluid collected was clear and appeared to be a good quality sample. However, conductivity $(1536 \mu \mathrm{S})$ and $\mathrm{pH}$ (11.4) laboratory measurements indicate the sample is not representative of ambient groundwater chemistry. The elevated $\mathrm{pH}$ and conductivity values are consistent with results from the 1993 samples collected from this well. This suggests the groundwater may have been contaminated with drilling and/or completion fluids. Despite the elevated $\mathrm{pH}$ and conductivity, the total dissolved inorganic carbon (DIC) is less than $20 \mathrm{ppm}$ which is unusually low for NTS groundwater. The average groundwater DIC at the NTS is roughly 270 ppm (from data in Rose et al., 1997).

An analysis of the charge balances generated from the cation and anion analyses completed on this sample suggests that there may be a problem with the analytical results. The fluid sample is electrically neutral, and so the cationic charge should balance the anionic charge. The major cationic and anionic species are used to determine the charge balance of the solution. An equation used to study error associated with analytical results is:

$$
E=\frac{\sum z m_{c}}{\sum z m_{a}}
$$

where $\mathrm{E}$ is the charge balance, $\mathrm{z}$ is the charge of the species, $\mathrm{m}_{\mathrm{c}}$ is the molality of common cationic species, and $m_{a}$ is the molality of common anionic species (Freeze \& Cherry, 1979). A value of $E=1$ indicates the charge input from the cationic species equals that from the anionic species and the solution is electrically neutral.

Using equation [1], the resultant charge balance for the UE3e\#4 $\mathrm{P}-1$ sample was $>3$. A possible explanation for this variance from unity is that one or more cationic analytes not included in the scope of the initial analyses are present at unusually high concentrations. A more likely cause for the deviation is the unusually high concentration of $\mathrm{OH}$ caused by the dissociation of water at the elevated $\mathrm{pH}$ of 11.4.

The decay-corrected tritium content of the fluid (see Table 3) is over 25 times greater than the decay-corrected activity found in this piezometer in 1993 (Smith et al., 1998). Because the chemistry of the fluid sample is obviously not an accurate assessment of formation waters, the shift in tritium activity may be anomalous. 


\section{Well UE3e \#4 Piezometer \#2}

On September 23, 1998 fluid samples were collected from this well at a depth of $573 \mathrm{mbs}$. The samples were not collected within the screened interval between 575.2 and $581.6 \mathrm{mbs}$ since the tool and bailer assembly touched bottom at $575 \mathrm{mbs}$. The presence of material within the screened interval suggests drilling tluids, completion fluids, or a similar type of construction or completion material is present at the bottom of the well. This conclusion is supported by the high conductivity $(4620 \mu \mathrm{S})$ and $\mathrm{pH}(12.2)$ of the fluid collected from depth. Like UE3e\#4 P-1, the DIC in UE3e \#4 P-2 was remarkably low at 4 ppm. See Tables 1-3 for analytical data.

Similar to UE3e \#4 P-1, the charge balance for UE3e \#4 P-2 deviated from unity. The cause for the discrepancy in electroneutrality is speculated to be similar to UE3e \#4 P-1. The decay-corrected tritium activity in the 1998 sample (see Table 3) is roughly $50 \%$ of that found in the 1993 sample (Smith et al., 1998). Again, a reason for the significant tritium shift will not be advanced until the well is adequately purged, and a representative fluid sample is collected and analyzed.

\section{Well UE3e \#4 Piezometer \#3}

On September 24, 1998 a fluid sample was collected from $503 \mathrm{mbs}$. Despite efforts to collect a set of full tandem bailers, approximately $50 \mathrm{ml}$ of fluid were returned to the surface. The sample was more viscous than water with a consistency resembling cement. After an initial inspection of the returned fluid, we decided to abort future attempts to collect samples from this piezometer until it had been sufficiently cleaned by further bailing or other means. While a tritium analysis was completed on the fluid from UE3e \#4 Piezometer \#3 and is presented in Table 1, an interpretation is not warranted given the poor quality of the sample.

\section{Well U19vPS1ds}

Well U19vPS1ds was sampled on September 22 and 23, 1998 at a depth of $1091 \mathrm{mbs}$. This is a post-shot well that has been sampled previously (see Smith et al., 1998). The well is unique because subsurface temperatures are unusually high over twenty-five years after the test was conducted. Workers present at the post-shot drilling recount instances of melted and deformed tools extracted from the hole because of the high temperatures at depth.

As of December 1996, the peak temperature in this well was almost $160^{\circ} \mathrm{C}$ at about 1150 mbs. Fluid samples were collected relatively high in the water column at $1091 \mathrm{mbs}$ (TD is $1164 \mathrm{mbs}$ ) because of the extreme temperatures at depth. From a 1996 geothermal temperature $\log$ of the well bore, the temperature at $1150 \mathrm{mbs}$ was $100^{\circ} \mathrm{C}$. The higher temperatures lower in the water column may have damaged the electronic components of the sampling equipment if the tool was lowered further into the well. Analytical results of fluid collected from this well are presented in Tables 1-3. 
Using equation [1], the dissolved ion charge balance for the sample collected on September 22, 1998 is 1.02 . This indicates a roughly $2 \%$ error in electroneutrality calculated from the analytical data. This small uncertainty is acceptable and indicates successful analysis of the fluid sample. From the major anion and cation analyses, the fluid is a sodium bicarbonate groundwater common to the volcanic rocks of Pahute Mesa.

The dissolved inorganic carbon (DIC) concentration is higher than almost all other groundwaters collected from Pahute Mesa. U19vPS 1ds has a DIC of $280 \mathrm{ppm}$ relative to an average concentration of $114 \mathrm{ppm}$ average for Pahute Mesa groundwaters calculated from the data in Rose et al. (1997), and unpublished data. In addition to the unusually high DIC concentration, the $\delta^{13} \mathrm{C}$ content of the DIC is dramatically shifted to $+27.0 \%$ relative to the PDB standard. The average $\delta^{13} \mathrm{C}$ value for Pahute Mesa is $-6.3 \%$ (from data in Rose et al., 1997). The DIC and $\delta^{13} \mathrm{C}$ averages presented here do not include data from well U19qPS1d (CAMEMBERT) where similar enrichments in $\delta^{13} \mathrm{C}(+1.6 \%$ ) and DIC (1016 ppm) were observed. It is clear that some process is locally affecting the ${ }^{13} \mathrm{C}$ content of the DIC in both the U19vPS1ds and U19qPS1d wells.

The decay-corrected tritium activity of a fluid sample collected in 1998 was more than $10 \%$ lower than the decay-corrected activity level of a sample collected from a similar depth in June of 1996. Similarly, the ${ }^{137}$ Cs decay-corrected activity was also $\sim 10 \%$ lower in the sample collected in 1998 than a sample collected in June of 1996.

\section{Isolation of the Cavity-Chimney System}

Interpretation of borehole gas and fluid samples from U19qPS1d suggests the occurrence of methanogenesis in the sampled fluid volume (see Chapter 2 of this report and ANCD, 1999). Although gas samples were not collected from the borehole above the water table in U19vPS1ds, we speculate that chemical processes similar to U19qPS1d occur within U19vPS 1ds on the basis of the unusual enrichments in $\delta^{13} \mathrm{C}$ and DIC. These data support a hypothesis of a relatively closed system. It is possible the elevated temperatures at depth are encouraging degassing of the water effectively lowering the DIC.

Methanogenic processes occur in reducing environments. If methanogenesis is occurring at depth, this suggests the volume sampled in 1998 had little to no contact with the surrounding hydrologic environment. Ambient groundwaters on Pahute Mesa are oxidizing. The possibly reducing environment of wells U19qPS1d and U19vPS1ds may significantly alter the subsurface chemistry of residual radionuclides and may have important implications for radionuclide migration.

Oxygen and hydrogen stable isotope data provide further evidence that the subsurface cavity and chimney systems are relatively isolated. The $\delta \mathrm{D}$ and $\delta^{18} \mathrm{O}$ data for Pahute Mesa groundwaters are plotted in Figure 2. All the groundwaters are shifted from the global 
Figure 2. Pahute Mesa groundwater $\delta \mathrm{D}$ vs $\delta^{18} \mathrm{O}$.

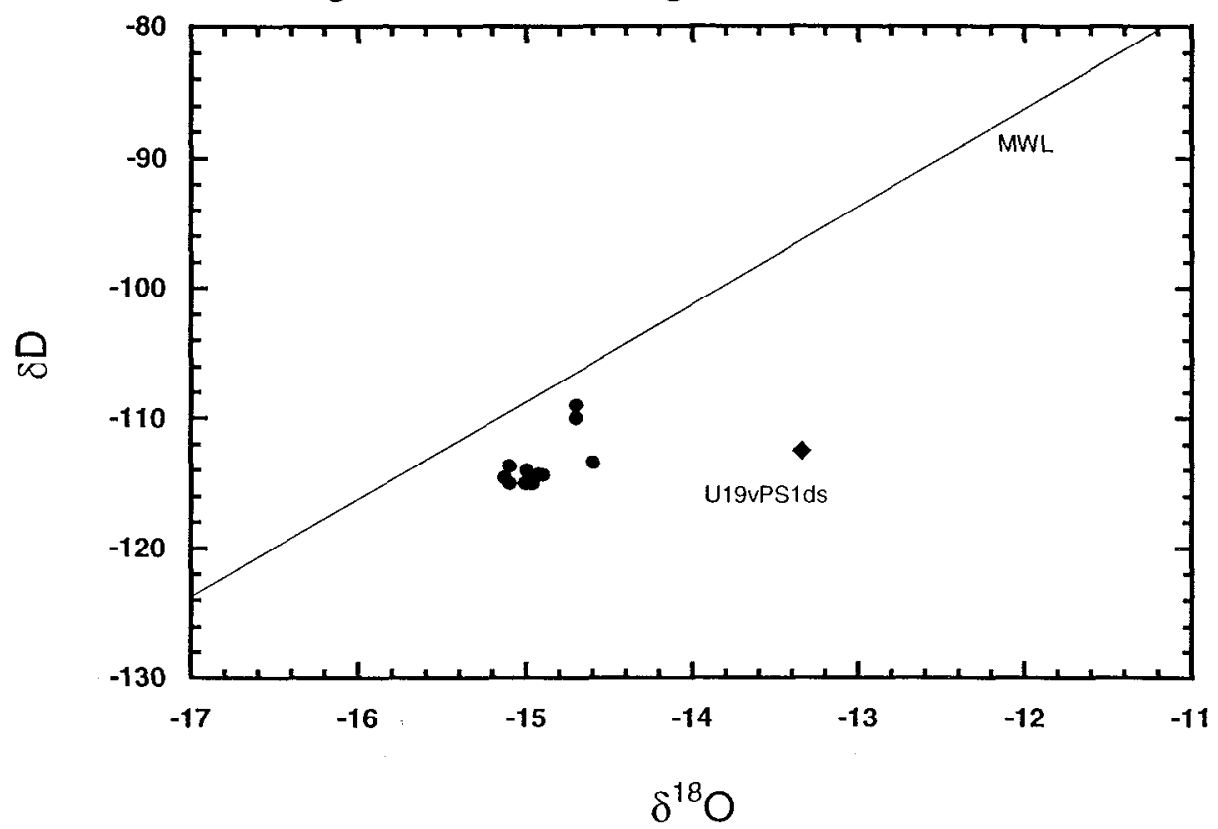

Figure 2: Pahute Mesa groundwater ranges between about $-14.6 \%$ to $-15.3 \%$ for $\delta^{18} \mathrm{O}_{\mathrm{S} M o w}$. The U19vPSIds sample is significantly shifted from the global meteoric water line. The trajectory of the shift is consistent with isotopic exchange between a fluid and the host rock.

meteoric water line (MWL). This shift may be due to evaporative processes occurring during recharge (Davisson et al, 1999). The $\delta^{18} \mathrm{O}$ data from the U19vPS1ds sample is significantly shifted to the right of the data points representing other Pahute Mesa groundwaters. The magnitude and direction of the shift from the MWL suggests rockwater interactions, where oxygen isotopes in the host lithology are exchanging with the oxygen isotopes in the groundwater. The deuterium reservoir in the host-rock is relatively insignificant relative to the oxygen reservoir. Therefore, as the oxygen isotopes ratios of the water are shifted by exchange with the host-rock, the deuterium isotopic ratios remain effectively unchanged.

Interpretation of data collected from U19vPS1ds and U19qPS 1d suggests the presence of closed or partially closed chimney and/or cavity systems. In addition, these closed systems appear to have a dramatically different chemistry than the regional scale flow regime. The population and extent of isolated cavity systems is not known, but should be further 
investigated because of the potential impact to radionuclide migration studies, and the conclusions drawn from those studies.

Further investigation of well U19vPS 1d is necessary to better understand the behavior of radionuclides in an underground environment with elevated temperatures. The collection of a sample pumped from deeper within the detonation cavity may provide additional insight to radionuclide behavior in a post-test environment.

\section{Well U4uPS2a}

Fluid samples from the DALHART post-shot well (U4uPS2a) were previously collected using a wire-line bailer and analyzed (see Smith et al., 1998 and Thompson, 1998). Samples collected in FY1993 and FY 1997 were contaminated in the subsurface with what appeared to be iron oxides, drilling fluids, and/or completion fluids. The FY1998 samples are similarly contaminated, however, the contamination appears to be less.

During FY1998, BN deployed a set of tandem Bennett pumps and pumped fluid from U4uPS2a. The pump intake was set around $500 \mathrm{mbs}$ and subsequently the pump rate was approximately 0.1 gallons per minute. Despite the slow pump rate, pumping fluid from a post-shot well to collect a sample is an improvement over the more conventional method of bailing. Due to safety concerns, personnel were required to be on-site while fluid was pumped and for this reason pumping was not continuous. Samples were collected from U4uPS2a on September 23, 1998. All fluid samples from this well were collected from a depth that is above the working point of the test.

Analytical results from U4uPS2a are presented in Tables 1-3. Using equation [1], the charge balance is approximately 0.4. A ratio of 0.4 is indicative of an excess of anionic species. This variance from unity may be an artifact of laboratory procedure rather than an analytical error since the cation sample was not filtered prior to acidification. In general, the concentration of major cations is higher in the 1998 sample than in the 1997 sample.

The sample contained unusually high concentrations of aluminum $(60 \mathrm{ppm})$ and silicon (333 ppm). These values are 10 to 1000 times greater than typical NTS groundwaters (Rose et al., 1997). The elevated aluminum and silicon levels may be due to the particulate contamination present in the well.

This well is of particular interest because several $\gamma$ emitting radionuclides $\left({ }^{60} \mathrm{Co},{ }^{106} \mathrm{Ru}\right.$, $\left.{ }^{125} \mathrm{Sb},{ }^{137} \mathrm{Cs},{ }^{226} \mathrm{Ra}\right)$, two $\beta$-emitting radionuclides $\left({ }^{3} \mathrm{H},{ }^{90} \mathrm{Sr}\right)$ and small amounts of $\alpha$-emitting radionuclides $\left({ }^{2.39} \mathrm{Pu},{ }^{240} \mathrm{Pu}\right)$ were found in samples collected from this well in 1993 and 1997 (see Smith et al., 1998). The sample was not analyzed for ${ }^{90} \mathrm{Sr}$, but all other radionuclides found in 1993 and 1997 were found in the 1998 sample. In general, the decay-corrected activity levels of radionuclides are lower than in previous samples. In 
contrast, the decay-corrected ${ }^{137} \mathrm{Cs}$ activity is higher in the 1998 sample by about a factor of 30 over the 1997 sample. Similarly, the decay-corrected ${ }^{3} \mathrm{H}$ activity is about $10 \%$ higher in the 1998 sample than the sample collected in 1997.

The decay-corrected activities of other $\gamma$-emitting radionuclides, such as ${ }^{60} \mathrm{Co},{ }^{106} \mathrm{Ru}$, and ${ }^{125} \mathrm{Sb}$, are lower by about $4 \%$ to $25 \%$. This decrease in ${ }^{60} \mathrm{Co}$ and ${ }^{125} \mathrm{Sb}$ activities are anticipated since these radionuclides have relatively short half-lives, on the order of 2.76 years to 5.27 years. The relatively small decrease in the decay-corrected activity of ${ }^{106} \mathrm{Ru}$ (about $4 \%$ ) is less than the anticipated decrease in activity due to radioactive decay. With a short half-life of roughly a year (368 days), the ${ }^{106} \mathrm{Ru}$ decay-corrected activity should have dropped by about 50\%, since the 1997 and 1998 samples were collected approximately a year apart. The pumped groundwater samples contained unexpectedly elevated levels of ${ }^{3} \mathrm{H},{ }^{106} \mathrm{Ru}$, and ${ }^{137} \mathrm{Cs}$. The reason for the increase is not known and requires further study.

Tritium and some of the other more mobile radionuclides are not surprisingly found above the working point in post-shot wells. The presence of more refractory radionuclide species (such as $\mathrm{Pu}$ ) above the working point suggests the relative mobility of some radionuclides. Further study is warranted to determine the manner of radionuclide migration (e.g., dissolved, adsorbed, absorbed, etc.), and the effect of any exotic in-situ physical phenomena, such as thermal gradient, that may facilitate migration.

The tandem Bennett pump tool establishes the possibility of cost-effectively collecting more representative cavity fluid samples. Collection and analysis of representative cavity fluids by this means will enhance our understanding of the hydrologic source term, and allow better predictions of radionuclide behavior at depth.

\section{References}

Analytical and Nuclear Chemistry Division (1999), Isotopic Analyses: Re-entry Well U19q-PS\#1d, Lawrence Livermore National Laboratory, unpublished letter report.

Davisson, M.L., Smith, D.K., Kenneally, J.M., Rose, T.P. (1999), Isotope Hydrology of Southern Nevada Groundwater: Stable Isotopes and Radiocarbon, Water Resources Research, v. 35, n. 1, pp. 279-294.

Freeze, R.A., and Cherry, J.A. (1979), Groundwater. Prentice-Hall, Inc., New Jersey, 604 p.

Goishi, W., Esser, B., Meadows, J., Namboodiri, N., Smith, D.K., Wild, J., Bowen, S., Baca, P., Olivas, L., Geoffrion, C., Thompson, J.L., Miller, C. (1994), Total Radionuclide Inventory Associated with Underground Nuclear Tests Conducted at the Nevada Test Site 1955-1992 (U), Los Alamos National Laboratory, LA-CP-94-0222, Secret-Restricted Data.

Rose, T.P., Kenneally, J.M., Smith, D.K., Davisson, M.L., Hudson, G.B., Rego, J. (1997), Chemical and Isotopic Data for Groundwater in Southern Nevada, UCRL-ID-128000, 38 p. 
Smith, D.K., Kersting, A.B, Rose, T.P., Kenneally, J.M., Hudson, G.B.; Eaton, G.F., Davisson, M.L. (1998), Hydrologic Resources Management Program and Underground Test Area Operable Unit FY 1997 Progress Report, UCRL-ID-130792, 92 p.

Thompson, J.L., Chapman, J.B., Clarke, J.E., Conaway, J.G., Drellack, S.L. Jr., Hawkins, W.L., Henderson, R. W., Long, W.A., Maestas, S., Mathews, M., Mitchell, A.J., Rego, J., and Schwitchtenberg, D.R. (1991), Interim Report of the Drilling History and Analysis for Nevada Test Site Hole UE3e\#4, Los Alamos National Laboratory, LA-12042-MS, 204 p.

Thompson, J.L. (1995), Laboratory and Field Studies Related to the Hydrologic Resources Management Program, October 1, 1994-September 30, 1995, Los Alamos National Laboratory, LA-13064-PR, 37p.

Thompson, J.L, Dozier, B.L., Duncan, D.W., Efurd D.W., Finnegan D.L., Kersting, A.B., Martinez, B.A., Ortego, P.K., Rokop, D.J., Smith, D.K., and Thompson, B.K. (1998), Laboratory and Field Studies Related to Radionuclide Migration at the Nevada Test Site, October 1, 1996 - September 30, 1997, Los Alamos National Laboratory, LA-13419-PR, 39 p. 


\title{
Cavity or Near-Cavity "Hot" Well Analyses FY 1998
}

\author{
Table I
}

Major cations and anions

\begin{tabular}{|r|l|l|l|r|r|}
\hline Well & Test & Depth & $\begin{array}{l}\text { Collection } \\
\text { Date }\end{array}$ & pH & Conductivity \\
\hline Units & & $(m b s)$ & & & \\
\hline & & & & $9 S)$ \\
\hline U19v PS1 ds & Almendro & $1091.2^{*}$ & $22-S e p-98$ & & 753 \\
\hline U19v PS2 ds & Almendro & $1091.2^{\star}$ & $23-S e p-98$ & 8.1 & 370 \\
\hline U4u PS2A & Dalhart & & $23-S e p-98$ & 11.4 & 1536 \\
\hline UE3e\#4 P1 & Aleman & 658.4 & 23-Sep-98 & 12.2 & 4620 \\
\hline UE3e\#4 P2 & Aleman & 573.0 & $23-S e p-98$ & & \\
\hline UE3e\#4 P3 & Alcman & 502.9 & $24-S e p-98$ & & \\
\hline & & & & & \\
\hline
\end{tabular}

${ }^{\star}$ measured slant depth below surface in meters

\begin{tabular}{|c|c|c|c|c|c|c|c|c|c|}
\hline Well & Test & $\mathrm{Ca}$ & $\mathrm{Mg}$ & $\mathrm{Na}$ & $\mathbf{K}$ & $F$ & $\mathrm{Cl}$ & $\mathrm{SO}_{4}$ & $\begin{array}{l}\mathrm{DIC}^{\dagger} \\
\left(\text { as } \mathrm{HCO}_{3}\right)\end{array}$ \\
\hline Units & & $(p p m)$ & $(p p m)$ & $(p p m)$ & $(p p m)$ & $(p p m)$ & $(p p m)$ & $(p p m)$ & $(\mathrm{ppm})$ \\
\hline U19v PS1 ds & Almendro & 0.53 & 0.07 & 152 & 10.1 & 9.8 & 40 & 3.4 & 281 \\
\hline U19v PS2 ds & Almendro & 0.33 & 0.02 & 146 & 9.7 & & & & \\
\hline U4u PS2A & Dalhart & 17.4 & 10.5 & 73 & 32.2 & 0.8 & 7.3 & 11.4 & 168 \\
\hline UE3e\#4 P1 & Aleman & 29.8 & 0.02 & 212 & 6.0 & 4.61 & 22.1 & 88.7 & 19 \\
\hline UE3e\#4 P2 & Aleman & 262 & 0.004 & 192 & 16.2 & 2.36 & 91.6 & 4.28 & 4 \\
\hline UE3e\#4 P3 & Aleman & & & & & & & & \\
\hline & & & & & & & & & \\
\hline
\end{tabular}

† Dissolved inorganic carbon 
Table II

Trace Elements and Environmental Isotopes

\begin{tabular}{|l|l|l|l|r|r|r|r|r|r|}
\hline Well & Test & Depth & $\begin{array}{l}\text { Collection } \\
\text { Date }\end{array}$ & Li & B & Al & \multicolumn{1}{l|}{ Si } & Mn & Fe \\
\hline Units & & $(m b s)$ & & $(p p m)$ & $(p p m)$ & $(p p m)$ & $(p p m)$ & $(p p m)$ & $(p p m)$ \\
\hline & & & & & & & & & \\
\hline U19v PS1 ds & Almendro & $1091.2^{\star}$ & $22-$ Sep-98 & 0.26 & 1.61 & 0.09 & 8.88 & 0.01 & 0.1 \\
\hline U19v PS2 ds & Almendro & $1091.2^{\star}$ & 23-Sep-98 & 0.25 & 1.54 & 0.14 & 8.33 & $<0.01$ & 0.07 \\
\hline U4u PS2A & Dalhart & & $23-$ Sep-98 & 0.1 & 0.19 & 60 & 333 & 0.44 & 58.5 \\
\hline UE3e\#4 P1 & Aleman & 658.4 & 23-Sep-98 & 0.07 & 0.15 & 3.35 & 12.9 & $<0.01$ & 0.09 \\
\hline UE3e\#4 P2 & Aleman & 573.0 & 23-Sep-98 & 0.22 & $<0.06$ & 0.63 & 1.01 & $<0.01$ & $<0.02$ \\
\hline UE3e\#4 P3 & Aleman & 502.9 & 24-Sep-98 & & & & & & \\
\hline & & & & & & & & & \\
\hline
\end{tabular}

${ }^{*}$ measured slant depth below surface in meters

$<$ detection limit

\begin{tabular}{|l|l|l|l|l|r|r|r|r|r|}
\hline Well & Test & Ni & As & Se & Sr & Mo & Ba & Pb & U \\
\hline Units & & $(p p m)$ & $(p p m)$ & $(p p m)$ & $(p p m)$ & $(p p m)$ & $(p p m)$ & $(p p m)$ & $(p p m)$ \\
\hline & & & & & & & & & \\
\hline U19v PS1 ds & Alruendru & $<0.01$ & 0.043 & $<0.003$ & 0.01 & 1.08 & $<0.01$ & 0.011 & $<0.0005$ \\
\hline U19v PS2 ds & Almendro & $<0.01$ & 0.056 & $<0.003$ & 0.01 & 1.01 & $<0.01$ & 0.0021 & $<0.0005$ \\
\hline U4u PS2A & Dalhart & $<0.01$ & $<0.003$ & $<0.003$ & 0.05 & $<0.01$ & 0.1 & 0.0009 & 0.0041 \\
\hline UE3e\#4 P1 & Aleman & $<0.01$ & $<0.003$ & $<0.003$ & 0.13 & 0.04 & 0.04 & 0.011 & $<0.0005$ \\
\hline UE3e\#4 P2 & Aleman & $<0.01$ & $<0.003$ & $<0.003$ & 1.61 & 0.01 & 1.71 & 0.022 & $<0.0005$ \\
\hline UE3e\#4 P3 & Aleman & & & & & & & & \\
\hline & & & & & & & & & \\
\hline
\end{tabular}

\begin{tabular}{|c|c|c|c|c|c|}
\hline Well & Test & $\delta^{18} O_{\text {SMOW }}$ & $\delta \mathrm{D}_{\text {SMOW }}$ & ${ }^{14} \mathrm{C}$ & $\delta^{13} C_{\mathrm{PDB}}$ \\
\hline Units & & (\%) & (\%) & (fmc) & $(\%)$ \\
\hline U19v PS1 ds & Almendro & -13.34 & -112.5 & 279.31 & +27.04 \\
\hline U19v PS2 ds & Almendro & & & & \\
\hline U4U PS2A & Dalhart & -12.91 & -100.1 & 1182.22 & -9.60 \\
\hline UE3e\#4 P1 & Aleman & -14.12 & -109.9 & & -13.81 \\
\hline UE3e\#4 P2 & Aleman & -14.22 & -107.1 & & \\
\hline UE3e\#4 P3 & Aleman & & & & \\
\hline & & & & & \\
\hline
\end{tabular}


Table III

Radioisotopes

\begin{tabular}{|c|c|c|c|c|c|c|c|}
\hline Well & Test & Depth & $\begin{array}{l}\text { Collection } \\
\text { Date }\end{array}$ & ${ }^{3} \mathrm{H}$ & ${ }^{3} \mathrm{H}$ & ${ }^{60} \mathrm{Co}$ & ${ }^{60} \mathrm{Co}$ \\
\hline Units & & (mbs) & & $(p C i / L)$ & $(p C i / L)$ & $(p C i / L)$ & $(p C i / L)$ \\
\hline Half-life (a) & & & & 12.32 & 12.32 & 5.272 & 5.272 \\
\hline Ref. date & & & & collect. & $1 / 1 / 94$ & collect. & $1 / 1 / 94$ \\
\hline U19v PS1 ds & Almendro & $1091.2^{*}$ & 22-Sep-98 & $1.59 e+08$ & $2.08 e+08$ & $<8.57 \mathrm{e}-02$ & \\
\hline U19v PS2 ds & Almendro & $1091.2^{*}$ & 23-Sep-98 & $1.63 e+08$ & $2.12 \mathrm{e}+08$ & - & \\
\hline U4U PS2A & Dalhart & & 23-Sep-98 & $1.62 \mathrm{e}+07$ & $2.11 \mathrm{e}+07$ & $7.16 \mathrm{e}+00$ & $1.33 e+01$ \\
\hline UE3e\#4 P1 & Aleman & 658.4 & 23-Sep-98 & $6.55 e+06$ & $8.54 e+06$ & - & \\
\hline UE3e\#4 P2 & Aleman & 573.0 & 23-Sep-98 & $1.61 \mathrm{e}+04$ & $2.10 e+04$ & - & \\
\hline UE3e\#4 P3 & Aleman & 502.9 & 24-Sep-98 & $3.72 e+05$ & $4.85 e+05$ & - & \\
\hline
\end{tabular}

* measured slant depth below surface in meters

$<$ detection limit

- not analyzed

\begin{tabular}{|r|l|r|r|r|r|r|r|}
\hline Well & \multicolumn{1}{l|}{ Test } & \multicolumn{1}{l|}{${ }^{85} \mathbf{K r}$} & \multicolumn{1}{l|}{${ }^{85} \mathbf{K r}$} & ${ }^{106} \mathbf{R u}$ & ${ }^{106} \mathbf{R u}$ & \multicolumn{1}{l|}{${ }^{125} \mathbf{S b}$} & \multicolumn{1}{l|}{${ }^{125} \mathbf{S b}$} \\
\hline Units & & $(p C i / L)$ & $(p C i / L)$ & $(p C i / L)$ & $(p C i / L)$ & $(p C i / L)$ & $(p C i / L)$ \\
\hline Half-life (a) & & 10.72 & 10.72 & 1.02 & 1.02 & 2.76 & 2.76 \\
\hline Ref. date & & collect. & $1 / 1 / 94$ & collect. & $1 / 1 / 94$ & collect. & $1 / 1 / 94$ \\
\hline & & & & & & & \\
\hline U19v PS1 ds* & Almendro & - & & $<8.43 \mathrm{e}-01$ & & $\leq 2.52 \mathrm{e}-01$ & \\
\hline U19v PS2 ds & Almendro & - & & - & & - & \\
\hline U4u PS2A & Dalhart & $2.90 \mathrm{e}+04$ & $3.94 \mathrm{e}+04$ & $1.18 \mathrm{e}+01$ & $2.93 \mathrm{e}+02$ & $7.14 \mathrm{e}+01$ & $2.34 \mathrm{e}+02$ \\
\hline UE3e\#4 P1 & Aleman & - & & - & & - & \\
\hline UE3e\#4 P2 & Aleman & - & & - & & - & \\
\hline UE3e\#4 P3 & Aleman & - & & - & & - & \\
\hline & & & & & & & \\
\hline
\end{tabular}

\begin{tabular}{|c|c|c|c|c|c|}
\hline Well & Test & ${ }^{137} \mathrm{Cs}$ & ${ }^{137} \mathrm{Cs}$ & ${ }^{239+240} \mathrm{Pu}$ & ${ }^{239+240} \mathrm{Pu}$ \\
\hline Units & & $(p C i / L)$ & $(p C i / L)$ & $(p C i / L)$ & $(p C i / L)$ \\
\hline Half-life (a) & & 30.17 & 30.17 & 6560 & 6560 \\
\hline Ref. date & & collect. & $1 / 1 / 94$ & collect. & $1 / 1 / 94$ \\
\hline U19v PS1 ds & Almendro & $5.68 \mathrm{e}-01$ & $6.33 e-01$ & $<3.71 \mathrm{e}-03$ & \\
\hline U19v PS2 ds & Almendro & -- & & $-\ldots$ & \\
\hline U4U PS2A & Dalhart & $7.51 e+01$ & $8.37 e+01$ & $1.25 \mathrm{e}-01 \neq$ & \\
\hline UE3e\#4 P1 & Aleman & - & & - & \\
\hline UE3e\#4 P2 & Aleman & - & & $\ldots$ & \\
\hline UE3e\#4 P3 & Aleman & - & & - & \\
\hline
\end{tabular}

$\ddagger$ high laboratory blank levels of $1.22 \mathrm{e}-02$ pCi for ${ }^{239+240} \mathrm{Pu}$ are associated with this sample. 


\title{
- Chapter 4 -
}

\section{Aged Nuclear Explosive Melt Glass: Radiography and Scanning Electron Microscope Analyses Documenting both Radionuclide Distribution and Glass Alteration}

\author{
Gail F. Eaton and David K. Smith
}

\section{Introduction}

The dissolution rate of the glass produced during an underground nuclear explosion largely controls the release of non-volatile radionuclides to groundwater. These glasses are important for two reasons: 1) they incorporate the majority of the radionuclides, and 2) they partition almost all of the actinide species (i.e., ${ }^{235} \mathrm{U},{ }^{238} \mathrm{U},{ }^{237} \mathrm{~Np},{ }^{239} \mathrm{Pu},{ }^{240} \mathrm{Pu}$ ). The actinides warrant specific attention since they are the radionuclide species having the highest toxicities (organ dose conversion factors: $\sim 10^{-6}$ to $10^{-5} \mathrm{~Sv} / \mathrm{Bq}$ ).

The United Nations Scientific Committee on the Effects of Atomic Radiation estimates that the total yield of all underground nuclear explosions conducted by the United States is 46 megatons (UNSCEAR, 1999). During an underground detonation, approximately 700 metric tons of rock surrounding the working (firing) point are melted per kiloton of explosive (Olsen, 1967). From these estimated values, a total of $\sim 32 \times 10^{6}$ metric tons of melt glass can be calculated as produced by United States underground nuclear testing. This glass is presently less than forty years old and will degrade, releasing constituent radionuclides over periods in excess of a thousand years. The release of actinide species into the subsurface environment is a direct function of the dissolution rate of this melt glass. Thercfore, understanding the behavior of melt glass under saturated conditions in the subsurface is important to developing a credible conceptual model for radionuclide release, and for providing validation of current numerical predictions.

Melt glass is believed to be produced from three sources immediately following a nuclear explosion (Figure 1; Borg et al., 1976): 1) initial condensation of vapor (plasma) produced during the explosion, 2) shock melting of the wall rock due to the high pressures and temperatures associated with the explosion, and 3) contact between the host rock and the melt at temperatures above the melting point of the rock. Glass from these sources gets variably mixed below the working point due to the condensation of the melt, flow of the melt down standing detonation cavity walls, and subsequent cavity collapse. The ability to chemically distinguish these end-members and trace the partitioning of actinides is important in the context of glass stability and radionuclide release.

The opportunity to study the in-situ degradation of melt-glass is rare since most post-shot melt glass samples were collected soon after the detonation. By design, post-shot drilling 


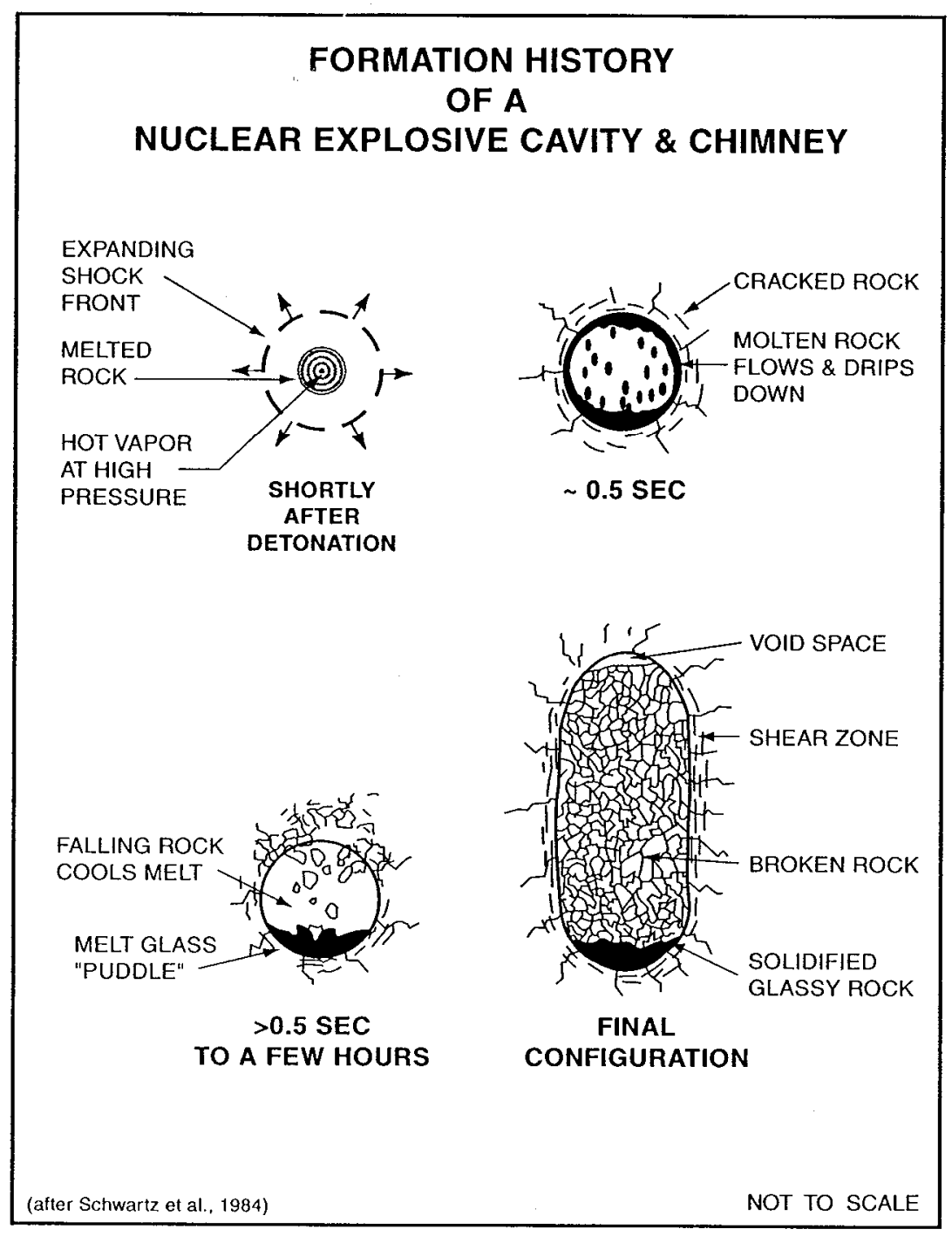

Figure 1. Schematic of early-time explosive phenomenology for an underground nuclear detonation.

typically targeted refractory radionuclides in the melt glass with high specific activities (and short half-lives) that could be used to assess the device performance. For this reason there were few re-entries at times greater than $\sim 1$ year following the detonation. For purposes of nuclear test readiness and revalidation, a limited number of post-shot drilling exercises were conducted years after the detonation of ccrtain tests. As a result, samples returned from these drill-backs below the water table provide a unique chance to study the physical and chemical state of glass that has interacted with groundwater for years following a detonation.

The current study has two objectives: 1) to design an $\alpha$-track radiography application to spatially resolve the distribution of transuranic actinide elements in these samples, and 2) 
to document glass-water surface alteration textures and chemistry. This work builds on previous investigations concerning the association of radioactivity and melt glass. The most notable of these investigations is the work of Borg (1975), who studied the composition and radiochemical profile of glasses from the 1966 Piledriver test which was fired above the water table in granodiorite of the Climax stock in Area 15 of the Nevada Test Site. Previous radiographic studies focused on understanding sorption of radionuclides onto geologic materials by placing samples in a solution with known uranium and americium concentrations (Thompson \& Wolfsberg, 1979; Smyth et. al., 1980). Radiography techniques were used to determine which geologic materials were most likely to adsorb the uranium and americium from the solution. The present study is unique for two reasons. We use radiographic techniques to study actinides incorporated into melt glass at the time of formation, and more importantly, we report on nuclear explosive melt glass which has remained underground in a saturated state for more than ten years.

\section{Sample Description}

Melt glass samples are from a Yucca Flat nuclear test, fired below the pre-shot water table in the Timber Mountain tuff. The event was re-drilled more than ten years after the time of the explosion and a set of samples collected from the cavity region. The three samples selected for analysis were collected below the water table in the vicinity of the "puddle," at a vertical depth of approximately $50 \mathrm{~m}$ below the level of the working point where molten glass coalesces at the bottom of the standing cavity. The glass samples consist of centimeter-sized pieces of homogeneous black glass with vesicles, and a banded glass that interleaves millimeter thick dark and light layers, and a pumiceous, lighter colorcd glass. Table I is list of the samples, sampling depths, and an abbreviated petrographic description.

Under low power magnification, all the glass samples are highly vesicular (Figure 2). Individual vesicles are round to ellipsoidal in shape and range from $<0.1 \mathrm{~mm}$ to greater than $3 \mathrm{~mm}$ in maximum dimension. In many cases, the quenching of glass has captured intermingled voids and bubbles. In particular, sample \#49 is highly charged with fine

TABLE I

\begin{tabular}{|l|l|l|}
\hline Sample Number & Sample Depth (Slant) & Description \\
\hline & & \\
\hline$\# 19 / 20$ & $\sim 660 \mathrm{~m}$ & Banded glass with light and dark laminae \\
\hline$\# 49$ & $\sim 660 \mathrm{~m}$ & Pink to gray highly vesiculated glass \\
\hline$\# 62$ & $\sim 645 \mathrm{~m}$ & Homogeneous black glass with vesicles \\
\hline
\end{tabular}

vesicles, and has a texture analogous to volcanic pumice. In many instances, the vesicles are completely lined with a rind of secondary minerals visible under low power magnification. In thin section, the glasses are devoid of crystalline phases and nearly 
isotropic under polarized light. Sample \#19/20 is slightly anisotropic under crossed polars and shows some evidence of internal strain. Flow banding can be seen in some samples and is accentuated by the elongation and orientation of vesicles and voids. Minute $(\sim 1$ $\mu \mathrm{m}) \mathrm{Fe}$ oxide phases entrained in the silicate melt are manifest as festooned bands. These bands are notable since identical oxide banding was noted in earlier petrographic studies of melt glass (Smith, 1995).

\section{Alpha Track Radiography}

Polished thin sections were made from each of the three glass samples. Samples were mounted in epoxy plugs and cut with a precision wafer saw to expose their cross-sectional area before being mounted on circular slides, ground to $\sim 30 \mu \mathrm{m}$ thickness, and then finished to a high polish. Two thin sections were cut and prepared for sample \#62; one of $30 \mu \mathrm{m}$ standard thickness and another $>30 \mu \mathrm{m}$ in thickness. All three $30 \mu \mathrm{m}$ thin sections were analyzed using $\alpha$-radiography techniques with varying exposure times (Table II). TASTRAK CR-39, an $\alpha$-track detector produced by Track Analysis Systems, Ltd. in Bristol, U.K., was used to record the tracks madc by $\alpha$-particles emitted from the melt glass samples. This process involved taping a $2.5 \mathrm{~cm}$ square slide of the TASTRAK detector directly to each thin section. Following exposure times varying from 6 hours to 21 days, the detector slides were etched to enlarge the $\alpha$-tracks recorded by the detector, following a procedure recommended by Track Analyses Systems, Ltd. This procedure recommends an etching time of 2 to 6 hours in $76^{\circ} \mathrm{C}, 6.25 \mathrm{~N}$ sodium hydroxide $(\mathrm{NaOH})$ solution. For the purposes of this study, an etching time of 2 hours at $70^{\circ}$ to $75^{\circ} \mathrm{C}$ in a $6.25 \mathrm{~N} \mathrm{NaOH}$ solution was sufficient to make the $\alpha$-tracks clearly visible under low power magnification (refer to Table II in the text). A hotplate with a magnetic stirrer running at low speed helped keep all surfaces of the detector slides immersed in the hot $\mathrm{NaOH}$ solution during the etching process.

Only two samples show evidence of $\alpha$-activity recorded by the TASTRAK detectors. The detectors for sample \#62 have the highest density of $\alpha$-tracks, even with an exposure time of only 6 hours. In fact, the $\alpha$-tracks from sample \#62 are so dense that the exact outline of the sample and the vesicles can be clearly seen on the detector-with or without magnification (figure 2).

Sample \#19/20 also emitted high enough activity levels for the TASTRAK detectors to record $\alpha$-tracks, but only after 8 days of exposure. Using a petrographic microscope, high track density is observed in association with the dark glass laminae in sample \#19/20. This darker colored glass phase closely rescmbles sample \#62. Even though some tracks can be seen in the lighter colored laminae of sample \#19/20, they are very sparse. In general, the distribution of $\alpha$-tracks is approximately uniform in the dark glass of both samples (\#62 and \#19/20. Sample \#49 produced no $\alpha$-tracks, even after 21 days of exposurebut it should be noted that this sample contained no dark melt glass. 


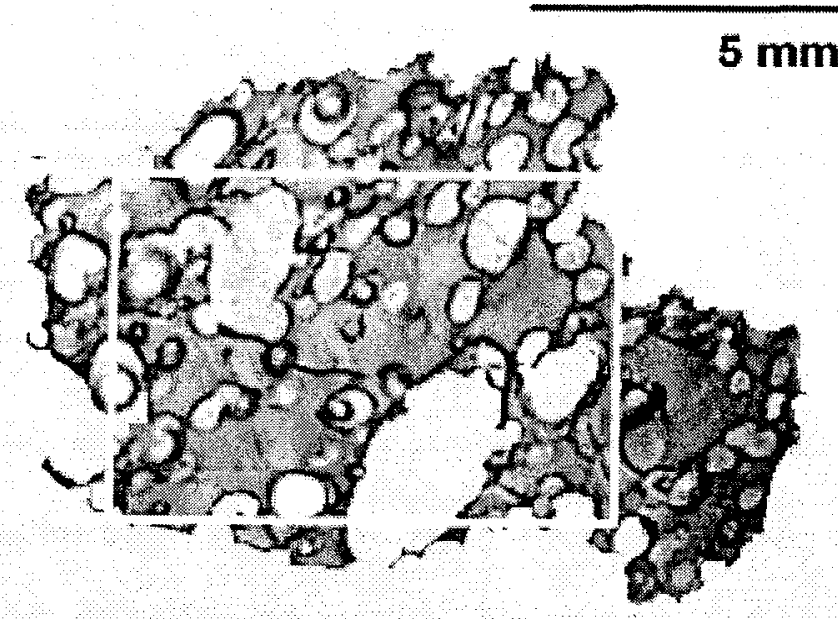

\#62 thin section

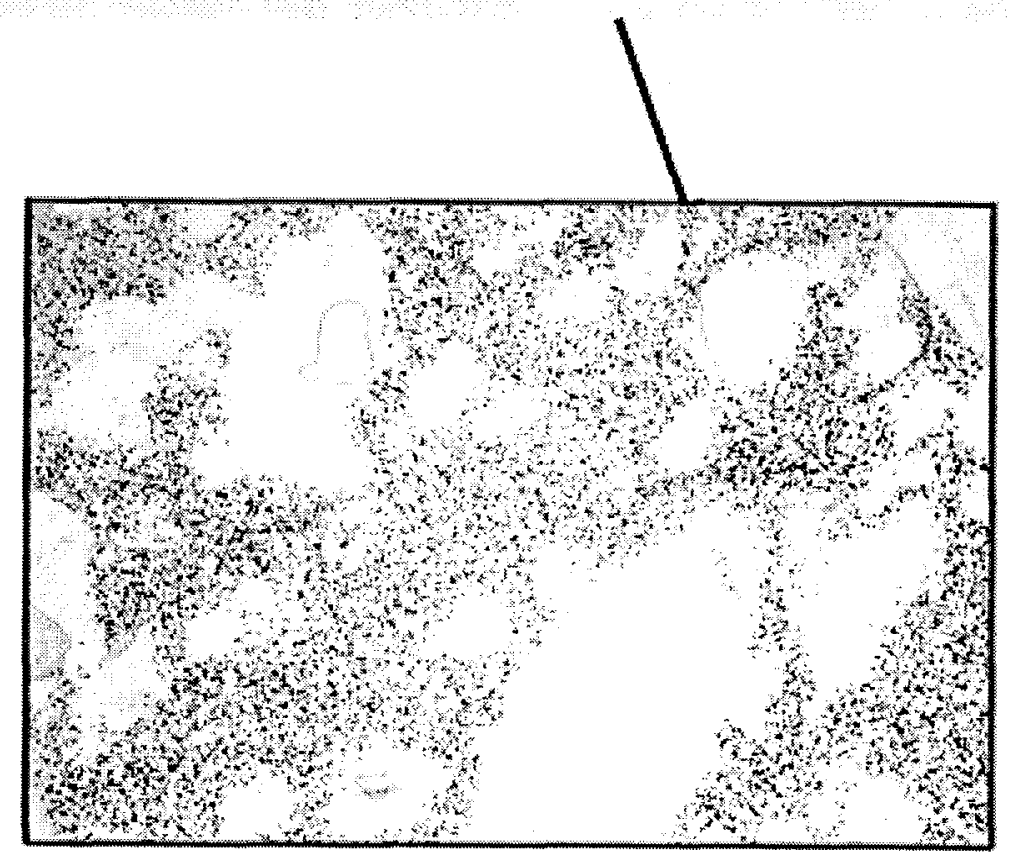

\#62 alpha tracks

Figure 2: Top: thin section photograph of sample \#62. Uncrossed polars. Vesicles are $\sim 3 \mathrm{~mm}$ in maximum dimension. Secondary reaction layers have developed on the rims of some of the vesicles. Bottom: photograph of a TASTRAK detector from sample \#62. Note that there is no $\alpha$-radiation from within the vesicles, conspicuously making the outline of the glass visible. 
TABLE II

\begin{tabular}{|l|l|l|l|l|}
\hline $\begin{array}{l}\text { Sample/ } \\
\text { Experiment }\end{array}$ & $\begin{array}{l}\text { TASTRAK } \\
\#\end{array}$ & $\begin{array}{l}\text { Exposure } \\
\text { (days) }\end{array}$ & $\begin{array}{l}\text { Development } \\
\left({ }^{\circ} \mathbf{C}, \text { hours) }\right.\end{array}$ & Results \\
\hline EXP 1 & & & & \\
\hline$\# 49$ & 23 & 1 & $75^{\circ}, 6$ & no tracks \\
\hline$\# 62$ & 17 & 1 & $75^{\circ}, 6$ & $\alpha$-tracks detected \\
\hline$\# 19 / 20$ & 30 & 1 & $75^{\circ}, 6$ & no $\alpha$-tracks \\
\hline EXP 2 & & & & \\
\hline$\# 49$ & 25 & 1 & $70^{\circ}, 2$ & no $\alpha$-tracks \\
\hline$\# 62$ & 15 & 0.5 & $70^{\circ}, 2$ & $\alpha$-tracks detected \\
\hline$\# 19 / 20$ & 1 & 1 & $70^{\circ}, 2$ & no $\alpha$-tracks \\
\hline EXP 3 & & & & \\
\hline$\# 49$ & 21 & 0.25 & $70^{\circ}, 2$ & no $\alpha$-tracks \\
\hline$\# 62$ & 28 & 0.25 & $70^{\circ}, 2$ & $\alpha$-tracks detected \\
\hline$\# 19 / 20$ & 43 & 0.25 & $70^{\circ}, 2$ & no $\alpha$-tracks \\
\hline EXP 4 & & & & \\
\hline$\# 49$ & 27 & 1 & $75^{\circ}, 2$ & no $\alpha$-tracks \\
\hline$\# 62$ & 40 & 1 & $75^{\circ}, 2$ & $\alpha$-tracks detected \\
\hline$\# 19 / 20$ & 42 & 1 & $75^{\circ}, 2$ & no $\alpha$-tracks \\
\hline EXP 5 & & & & \\
\hline$\# 49$ & 8 & 8 & $75^{\circ}, 2$ & no $\alpha$-tracks \\
\hline$\# 19 / 20$ & 41 & 8 & $75^{\circ}, 2$ & $\alpha$-tracks detected \\
\hline EXP 6 & & & $75^{\circ}, 2$ & no $\alpha$-tracks \\
\hline$\# 49$ & 2 & 21 & & \\
\hline
\end{tabular}

Under magnification the $\alpha$-tracks have two basic geometries, circular and teardrop-shaped. The teardrop-shaped tracks are due to $\alpha$-particles traveling at an oblique angle to the surface of the thin section, while circular pits represent $\alpha$-particles traveling approximately perpendicular to the surface of the thin section. The length of the teardrop correlates with the trajectory and energy of the $\alpha$-particle as it enters the film (Fleisher, Price, and Walker, 1975).

\section{Radiochemistry}

The three glass samples were submitted for bulk analysis by gamma spectroscopy, but only sample \#62 was submitted for plutonium assay by $\alpha$-counting. The glasses contained $\gamma$ emitting radionuclides that include fission products $\left({ }^{125} \mathrm{Sb},{ }^{134} \mathrm{Cs},{ }^{137} \mathrm{Cs},{ }^{195} \mathrm{Eu}\right)$, activation products $\left({ }^{22} \mathrm{Na},{ }^{60} \mathrm{Co},{ }^{152} \mathrm{Eu},{ }^{154} \mathrm{Eu}\right)$ and residues of nuclear material fuels $\left({ }^{241} \mathrm{Am}\right)$. Alpha counting results from both thin sections of sample \#62 produced two distinct peaks. A smaller peak, with an energy level of $5.157 \mathrm{MeV}$, is associated with the $\alpha$-decay of ${ }^{239} \mathrm{Pu}$. A second peak had energy levels of 5.486 and $5.499 \mathrm{MeV}$ that correlate with ${ }^{241} \mathrm{Am}$ and 
${ }^{238} \mathrm{Pu} \alpha$-decay, respectively. Thermodynamic calculations and empirical results from postshot radiochemical diagnostics predict that $\sim 98 \%$ of the inventory of these refractory isotopes will be incorporated into the silicate glass created by shock melting of the rocks adjacent to ground zero (IAEA, 1998). Therefore, the presence of the Am, Eu, and $\mathrm{Pu}$ isotopes in these melt glass samples is consistent with the predictions from condensation theory for refractory radionuclides.

Activity ratios were calculated from the $\alpha$-counting results for both thin sections of sample \#62 using the equation:

$$
\frac{I_{A}}{I_{B}}=\frac{A}{B-A}=\frac{\left({ }^{238} P u+{ }^{241} A m\right) d p m}{\left({ }^{239} P u+{ }^{240} P u\right) d p m},
$$

where $I_{A}$ and $I_{B}$ are the corrected peak heights for the radionuclide pairs ${ }^{238} \mathrm{Pu}+{ }^{241} \mathrm{Am}$ and ${ }^{239} \mathrm{Pu}+{ }^{240} \mathrm{Pu}$, and $\mathrm{A}$ and $\mathrm{B}$ are the total peak heights for ${ }^{238} \mathrm{Pu}+{ }^{241} \mathrm{Am}$ and ${ }^{239} \mathrm{Pu}+{ }^{240} \mathrm{Pu}$ respectively. It is noteworthy that the activity ratio for the $30 \mu \mathrm{m}$ thin section is 1.5 times greater than for the $>30 \mu \mathrm{m}$ thin section, implying a heterogeneous distribution of $\mathrm{Pu}$ isotopes within the sample. However, the $\alpha$-counting results for this sample represent only what is emitted from the surface of each thin section. Since the actinide activity is distributed through out the glass substrate, the "infinite thickness" of this substrate must be considered. On an atomic scale, infinite thickness pertains to the loss of $\alpha$-particle energy due to ionization and elastic collisions with other atoms and molecules along the exit path (Friedlander ct al., 1981). As a result, $\alpha$-emitting actinides distributed through out these melt glass samples will produce a continuum of $\alpha$-energies, making it impossible to tell from what depth in the sample, or at what initial energy, the $\alpha$-particles are emitted.

\section{Analysis Using the Scanning Electron Microscope (SEM)}

Exposed surfaces on the melt glass samples (as recovered) were identified for analysis and carbon-coated in preparation for SEM analyses. The thin sections were examined under a field-emission scanning electron microscope, equipped with an energy dispersive analyzer. A reaction rind is clearly evident on the glass samples, and is particularly well developed as vesicle coatings in samples \#62 and \#19/20 (figures 3a and 3b). Photomicrographs of the reaction layer show an abrupt transition between the unaltered glass and the reaction layer. In some vesicles, the alteration layer is entirely absent-or only incompletely developed. In other vesicles, the alteration completely encircles the void space. The reaction layers are composed of minerals $1 \mu \mathrm{m}$ in size. The morphology and qualitative compositional data are consistent with the reaction layer being composed of clays, i.e. smectite; $(1 / 2 \mathrm{Ca}, \mathrm{Na})_{0.7}(\mathrm{Al}, \mathrm{Mg}, \mathrm{Fe})_{4}\left[(\mathrm{Si}, \mathrm{Al})_{8} \mathrm{O}_{20}\right] \bullet \mathrm{nH}_{2} \mathrm{O}$ and/or illite; $\mathrm{K}_{1-1.5} \mathrm{Al}_{4}\left[\mathrm{Si}_{7-6.5} \mathrm{Al}_{1-}\right.$ $\left.{ }_{1.5} \mathrm{O}_{20}\right](\mathrm{OH})_{4}$. However, the identity of these phases must be confirmed by $\mathrm{X}$-ray diffraction analysis. 


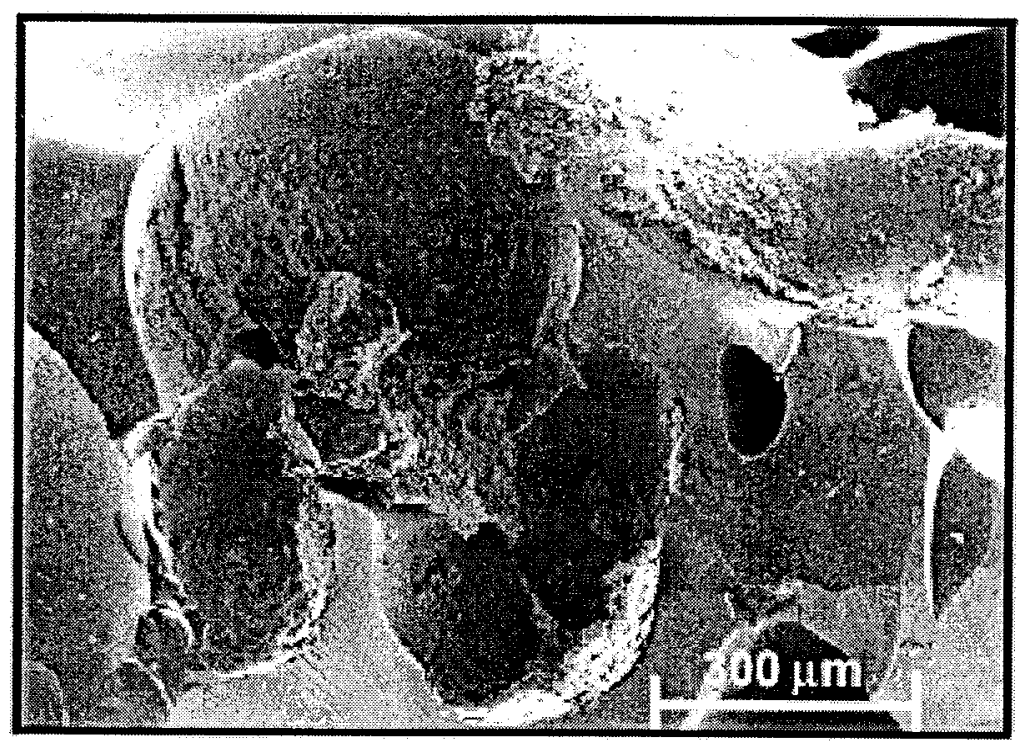

Fig. 3a: Sample $\$ 62$

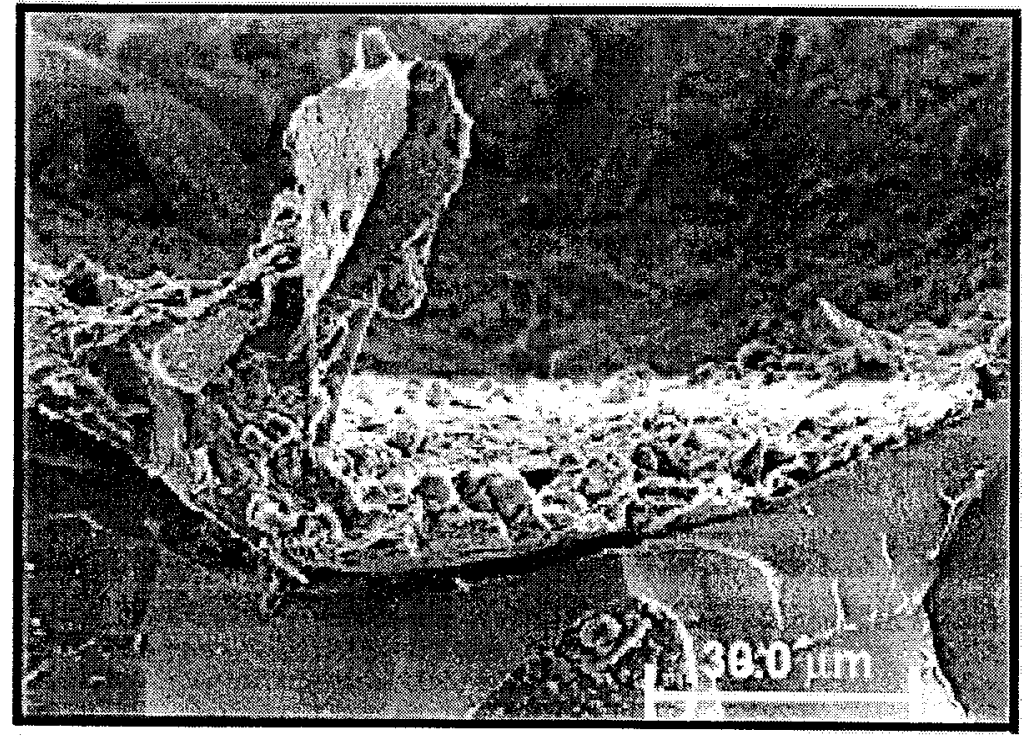

Fig 3b: Sample \#19/20

Figure 3: Polaroid photographs of SEM images. Shown are 3a) alteration layers lining vesicles from sample \#62, and $3 \mathrm{~b}$ ) a clearly defined alteration layer lining a vesicle in the dark glass from sample \#19/20. 


\section{Discussion}

The possibility that radionuclide residuals from underground nuclear tests could be released into groundwater was recognized early in the testing program (Batzel, 1959). Most current risk assessment studies regarding radionuclide release into the biosphere focus on the viability of using synthetic borosilicate glass to contain nuclear waste (Weber et al., 1997). These studies have thus spurred intense research and debate over the dissolution processes of both synthetic and naturally occurring glasses. Nuclear explosive melt glasses provide useful analogues for evaluating these processes. Since actinides are volumetrically incorporated in nuclear melt glass following an underground nuclear detonation, radionuclide release is a function of surface area, the composition of melt glass, and the chemistry of the reacting fluid. Detailed studies of melt glasses may provide new insight into the rate and mechanism of glass corrosion, the formation of alteration layers, and how these alteration layers affect the release of radionuclides into the groundwater (Smith, 1997).

For this study, $\alpha$-track radiography was an important tool for pinpointing areas of actinide activity in nuclear melt glasses. Specifically, the $\alpha$-track results indicate that the highest levels of activity are concentrated in the dark colored melt glass fractions. The dark color of the glass may be due to radiation damage, or the bulk chemical composition of the glass. Whether specific areas of high $\alpha$-activity are the result of compositional changes in the glass chemistry needs to be addressed. It is noteworthy that within the dark glass, the actinides are not preferentially associated with textural features. In addition, $\alpha$-counting results show that the $\alpha$-activity is primarily due to plutonium isotopes $\left({ }^{238} \mathrm{Pu},{ }^{239} \mathrm{Pu}\right)$, and the calculated activity ratios indicate that the distribution of $\mathrm{Pu}$ isotopes might vary within the dark colored melt glass itself. To our knowledge, this is the first time that the spatial variation of plutonium in nuclear melt glass has been documented.

SEM analyses of the melt glass samples show that secondary alteration minerals have formed on the surfaces of vesicles (figs $3 a$ \& $3 b$ ) in these samples. Previous studies have shown that exposure of glass to aqueous solutions ultimately results in the in situ formation of a secondary phase-typically a thin clay layer on the glass surface (e.g., Bourcicr, 1994; Abrajano et al., 1990; Petit et al., 1986; Bates et al., 1982). Naturally occurring basaltic glass in contact with both fresh and seawater are shown to form smectite and illite layers (Lutze et al. 1985; Byers et al., 1987). The presence of smectite and illite on exposed surfaces of silicate glasses in contact with water is also predicted on the basis of thermodynamic reaction modeling (Tompson et al., 1999). However, this is the first time that in situ formation of a secondary alteration layer is documented in nuclear melt glasses, and the aforementioned studies support our interpretation that these alteration layers are indeed clays.

Whereas many studies show that long-term interaction with aqueous solutions results in glass corrosion, precise modeling of the corrosion mechanism remains problematic 
(Strachan et al., 1993). Currently, the most commonly accepted mechanism for corrosion of glass is dissolution through hydration, where physical conditions, surface area, solution chemistry, and glass chemistry all have an influence on the rate of dissolution. For example, the rate of dissolution of amorphous silica is strongly controlled by both temperature and $\mathrm{pH}$ with dissolution processes slowing to minimum between $\mathrm{pH}$ of $\sim 6.5$ to 8.5, depending on the solution temperature (Wu et al., 1996; Strachan et al., 1993). Overall, dissolution rates increase dramatically with increasing temperature and $\mathrm{pH}$ values greater than $\sim 7$ (Mazer ct al., 1994).

For groundwaters at the NTS, which have an average $\mathrm{pH} \sim 8$, and an average temperature of $\sim 30^{\circ} \mathrm{C},{ }^{1}$ the dissolution rate of nuclear melt glass can be calculated using the glass

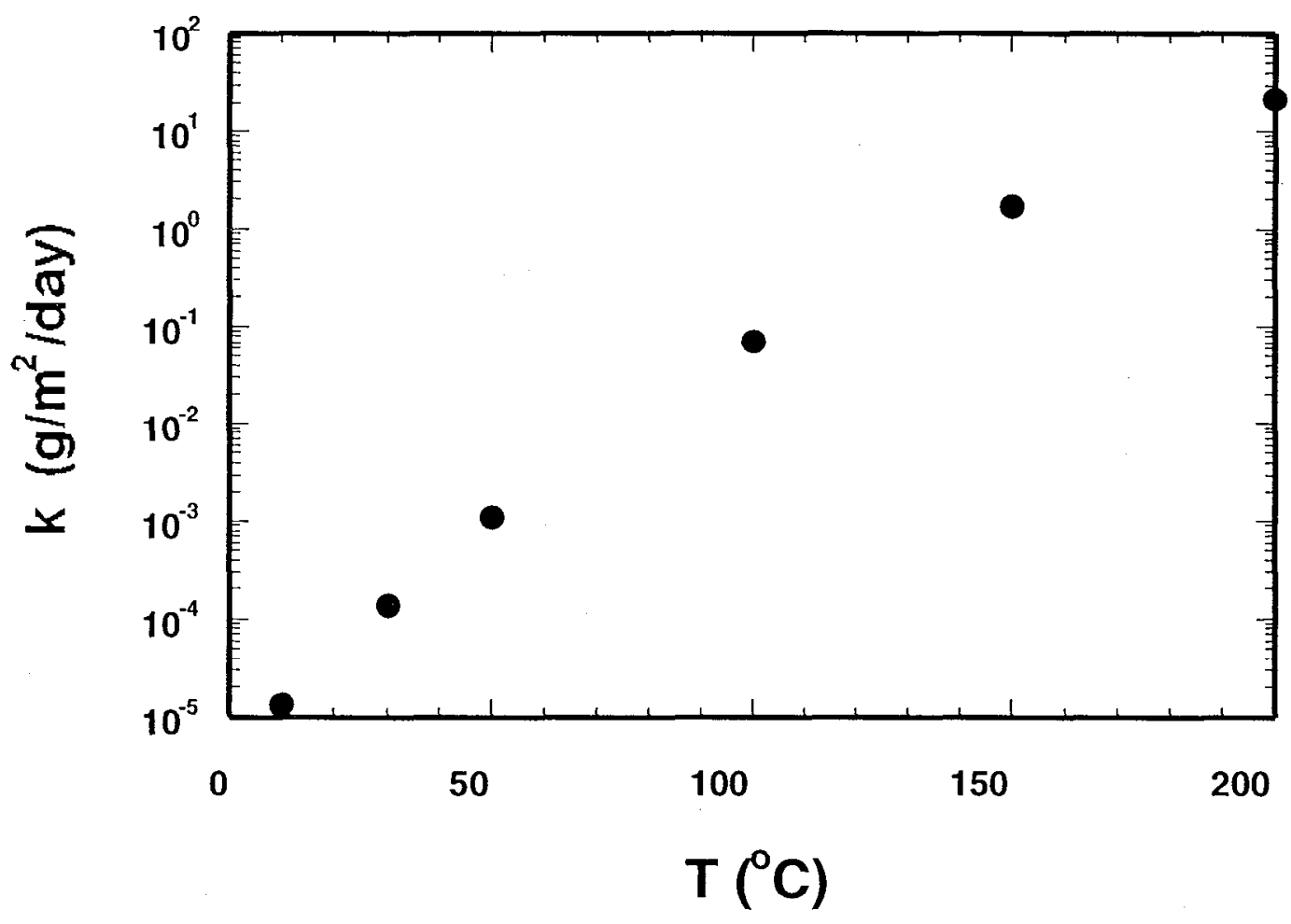

Figure 4: Dissolution rate of rhyolitic glass as a function of temperature for saturated melt glass at the NTS. A $\mathrm{SiO}_{2}$ content of $75 \mathrm{wt} \%$ is assumed, and pH held constant at 8 . After Tompson et al, 1999.

dissolution model outlined by Tompson et al., 1999. Using an average $\mathrm{SiO}_{2}$ content of 75 wt \% (typical for rhyolitic glass) from electron microprobe analyses of these samples

\footnotetext{
${ }^{1}$ Average values are calculated from temperature and $\mathrm{pH}$ pairs taken from tables I, II, and IV, compiled for LLNL's FY 1997 report (Smith et al., 1998).
} 
(D.K. Smith, unpublished data), the calculated glass dissolution rate would be approximately $10^{-4} \mathrm{~g} / \mathrm{m}^{2} /$ day at $30^{\circ} \mathrm{C}$. Figure 4 shows the effect of temperature on the dissolution rate of these samples. Note that the model predicts an exponential increase in dissolution rates with temperature, the rate increasing to $\sim 10^{-1} \mathrm{~g} / \mathrm{m}^{2} /$ day at $100^{\circ} \mathrm{C}$.

For these altered melt glass samples, it is unknown when the observed alteration layer formed. Knowing the temperature at which the alteration layer formed can help elucidate whether this layer formed soon after the detonation, or over the 10-year period that these samples existed in a saturated environment. Using the model of Tompson et al., and making a set of assumptions, we can speculate on the temperature required to produce the observed alteration layer. The necessary assumptions are: 1) that the system is chemically and hydrologically open, 2) that the thickness of the alteration layer represents the amount of glass that has been reacted, 3) that the alteration layer consists of clays having an average density of $2.5 \mathrm{~g} / \mathrm{cm}^{3}$, and 4) that the dissolution rates being discussed can be used to estimate the rate of secondary mineral formation. From the SEM analyses, the average thickness of the altcration layer is detcrmined to be $-5 \mu \mathrm{m}$. For a $1 \mathrm{~m}^{2}$ surface arca of glass that is in open communication with the groundwater, this corresponds to an alteration layer volume of $5 \times 10^{-6} \mathrm{~m}^{3}$ with a mass of $12.5 \mathrm{~g}$. Using the glass dissolution model of Tompson et al (1999), the mean groundwater temperature required to react $12.5 \mathrm{~g}$ of glass in 10 years is $\sim 62^{\circ} \mathrm{C}$. These temperatures and masses are reasonable considering that the model predicts that at $30^{\circ} \mathrm{C}, 0.5 \mathrm{~g} / \mathrm{m}^{2}$ of glass would be dissolved, while at $100^{\circ} \mathrm{C}, 263$ $\mathrm{g} / \mathrm{m}^{2}$ of glass would be dissolved in groundwater over a 10 year period. For the same time period, calculations show that a clay alteration layer formed in $30^{\circ} \mathrm{C}$ groundwater would only result in an average layer thickness of $0.2 \mu \mathrm{m}$. The implication is that the mean temperature of reaction producing the alteration layers in these samples must have been greater than ambient conditions for NTS groundwater.

Constraints on the temperatures for layer-forming reactions makes further speculation regarding the timing of clay layer formation possible, mainly through consideration of clay mineral stability - specifically illite and smectite. The temperature of hydration for most clays is $\sim 100^{\circ} \mathrm{C}$, implying that most hydrous clays begin to de-water and become unstable at temperatures over $100^{\circ} \mathrm{C}$. Illite is a lower temperature clay mineral that becomes unstable at temperatures over $\sim 140^{\circ} \mathrm{C}$ while smectite can remain stable to temperatures of $400^{\circ} \mathrm{C}$ (Velde, 1985). Therefore, these layers would probably begin to form as water temperatures within the cavity cooled below $400^{\circ} \mathrm{C}$. The overall implication is that the clay layers could have started forming shortly after the nuclear detonation, with the reaction rate slowing as the system cooled. This docs not mean that the length of time these glasses are in a saturated environment is not important. The saturation time may have direct implications regarding colloid formation and transport of radionuclides, and merits further study. 


\section{Conclusions}

-We have developed an $\alpha$-track radiography technique for analyzing nuclear melt glasses.

- Alpha tracks can be used to spatially resolve areas of high actinide activity in nuclear melt glass samples.

- Alpha activity is greatest in the darker colored melt glass.

- Alpha track density in the melt glass samples is homogeneous in the dark glass and not associated with specific textural fcatures.

- For the first time, in situ degradation and alteration of nuclear melt glasses has been documented.

-The secondary alteration layer probably formed at temperatures higher than ambient for the NTS.

\section{Future Work}

Areas of future research stemming from this study fall primarily into two areas. First, studies regarding the relationship between radionuclide distribution and melt composition and second, glass dissolution and alteration layer formation. Exploring these avenues may prove useful in elucidating radionuclide release into the environment.

Alpha track radiography can be applied to other nuclear melt glasses and natural volcanic glass samples to determine if the distribution of $\alpha$-activity is similar to the distribution observed here. Such analyses could show whether the $\alpha$-track distribution is solely the artifact of the physical conditions during and immediately following a nuclear detonation, or if similar distributions are also produced in natural volcanic glasses. Micro-beam and laser ablation analyses of a variety of nuclear melt glass samples may answer questions pertaining to the relationship between areas of high $\alpha$-activity and chemical composition of the melt glass. Does one indeed find a higher proportion of actinides in glasses with specific chemical compositions? In particular, it is of interest to determine whether a correlation exists between glasses having high concentrations of trace metals with high melting points and condensation of refractory radionuclides.

Kersting et al., (1999) demonstrated that Pu can be transported by colloidal material in groundwater. This raises the interesting possibility that the secondary alteration layer discussed in this report is a source for these colloids. The identification of the mineral species constituting the alteration layer is an integral part of determining whether these layers are a possible source of colloids. X-ray diffraction (XRD) analyses can be used to identify these mineral species, although it may be necessary to determine a method for separating the alteration phase from the bulk glass. Equally important to determining the composition of the alteration layer is knowing when this layer formed. In this report we speculate on the timing of alteration layer formation. Additional SEM analyses of melt glasses from both saturated and unsaturated environments may help determine whether 
most of this alteration layer forms quickly, soon after detonation or if it is a more gradual process.

\section{Acknowledgements}

Many thanks to the following LLNL research staff members for their participation in this study: Ken Moody of the Analytical and Nuclear Chemistry Division (ANCD) for his help in interpreting the $\alpha$-counting results. Jim Ferreira from the Materials Science and Technology Division (MSTD) who performed the SEM analyses. Annie Kersting and Tim Rose of the ANCD for their valuable scientific and editorial comments. And finally, Bill Bourcier from the Geosciences \& Environmental Technologies Division (GET) for sharing the spreadshcet for his glass dissolution model.

\section{References}

Abrajano, T.A., Bates, J.K., Woodland, A.B., Bradley J.P., and Bourcier W.L. (1990), Secondary phase formation during nuclear waste-glass dissolution. Clays and Clay Minerals, v. 38, n. 5, pp. 537-548.

Batzel, R.E. (1959), Radioactivity associated with underground nuclear explosions. Livermore National Laboratory, UCRL-5623, 15 p.

Byers, C.D., Jercinovic, M.J., and Ewing, R.C. (1987), A study of natural glass analogies as applied to alteration of nuclear waste glass. Argonne National Laboratory, NUREG/CR-4842, ANL-86-46.

Borg, I.Y. (1975), Radioactivity trapped in melt produced by a nuclear explosion. Nuclear Technology, v. 26, pp 88-100.

Borg, I.Y., Stone, R., Levy, H. B., and Ramspott, L. D. (1976), Information pertinent to the migration of radionuclides in ground water at the Nevada test site, part 1: Review and Analyses of Existing Information. Lawrence Livermore National Laboratory UCRL-52075 Pt. 1, 216 p.

Bourcier, W.L. (1994), Waste glass corrosion modeling: comparison with experimental results. Material Research Society Symposium Proceedings, v. 333, pp. 69-82.

Fleisher, R. L., Price, P.B., and Walker, R. M. (1975), Nuclear tracks in solids, principles and applications. University of California Press, Berkeley, 605 p.

Friedlander, G., Kennedy, J. W., Macias, E. S., and Miller, J. M. (1981), Nuclear and radiochemistry, Third edition. John Wiley \& Sons, Inc., New York, 684 p.

Guell, M.A. (1997), Subsurface transport of radionuclides at the Nevada Test Site, unpublished ph.D dissertation, University of California at Berkeley, $118 \mathrm{p}$.

International Atomic Energy Agency (1998), The radiological situation at the atolls of Mururoa and Fangataufa technical report, volume 3 : inventory of radionuclides underground at the atolls. IALAMFTR-3, 94 p.

Kersting, A. B., Efurd, D. W., Finnegan, D. L., Rohop, D. J., Smith, D. H. and Thompson, J. L. (1999), Migration of plutonium in groundwater at the Nevada Test Sitc. Naturc, v. 397, n. 6714, pp. 56-59. 
Lutze, W., Malow, G., Ewing, R.C., Jercinovic, M.J., and Keil, K. (1985), Alteration of basalt glasses; implications for modeling the long-term stability of nuclear waste glasses, Nature, v. 314, pp. 252255.

Mazer, J.J., and Walther, J.V. (1994), Dissolution kinetics of silica glass as a function of pH between 40 and 85-degrees-C. Journal of Non-crystalline Solids, v. 170, pp. 32-45.

Olsen, C.W. (1967), Time history of cavity pressure and temperature following a nuclear detonation in alluvium. Lawrence Livermore National Laboratory, UCRL-70379.

Petit, J. C., Brousse, C., Dran, J. C., and Della Mea, G. (1986), Use of fission tracks for deciphering the dissolution mechanism of silicate glasses. Nuclear Tracks, v. 12, nos. 1-6, pp. 847-850.

Shwartz, L., Piwinskii, A., Ryerson, F., Tewes, H., and Beiriger, W. (1984), Glass produced by underground nuclear explosions, in: Natural Glasses, North Holland (L.D. Pye, J.A. O'Keefe, and V.D., Frechette, eds.), pp. 559591.

Smith, D.K. (1997), Insights to the release of radionuclides from nuclear explosive melt glasses using natural analogs. Isotope Sciences Division, Lawrence Livermore National Laboratory, unpublished report, $27 \mathrm{p}$.

Smith, D.K. (1995), Characterization of nuclear explosive melt debris. Radiochimica Acta, v. 69, pp. $157-167$.

Smyth, J. R., Thompson, J. L., and Wolfsberg, K. (1980), Microautoradiographic studies of the sorption of $\mathrm{U}$ and Am on natural rock samples. Radioactive Waste Management, v. 1, no. 1, pp. 13-24.

Strachan, D.M., Bourcier, W.L., and McGrail, B.P. (1994), Toward a consistent model for glass dissolution. Radioactive Waste Management and Environmental Restoration, v. 19, pp. 129-145.

Thompson, J.L. (1999), Laboratory and field studies related to radionuclide migration at the Nevada Test Site. Los Alamos National Laboratory, LA-13576-PR, 28 p.

Thompson, J.L. (1996), Radionuclide distribution in a nuclear test cavity: The Baseball Event. Radiochimica Acta, v. 72, pp. 157-162.

Thompson, J. L., and Wolfsberg, K. (1979), Applicability of microautoradiography to sorption studies. Los Alamos National Laboratory Informational Report \#LA-7609-MS, 11 p.

Tompson, A.F.B., Bruton, C.J., Pawloski, G.A., Bourcier, W.L., Carle, S.F., Kersting, A.B., Rard, J.A., Shumaker, D.E., Smith, D.K. (1999), in: Evaluation of the hydrologic source term from underground nuclear tests in Frenchman Flat at the Nevada test site: The Cambric Test (A.F.B. Tompson, C.J. Bruton, and G.A. Pawloski, eds.). Lawrence Livermore National Laboratory, UCRL-ID-132300, 320 p.

United Nations (1999), Exposures from man-made sources of radiation. United Nations Scientific Committee on the Effects of Atomic Radiation. Report to the General Assembly, May 1998. United Nations publication A/AC.82/R.590, 150 p.

Velde, B. (1985), Clay minerals: a pysico-chemical explanation of their occurrence. In: Developments in sedimentology, v. 40. Elsevier Science Publishers, B.V., New York. 427 p.

Weber, W.J., Ewing R.C., Angell, C.A., Arnold, G.W., Cormack, A.N., Delaye, J.M., Griscom, D.L., Hobbs, L.W., Navrotsky, A., Price, D.L., Stoneham, A.M., and Weinberg, M. C. (1997), in: 
Radiation effects in glasses used for immobilization of high-level waste and plutonium disposition (W.J. Weber, ed.). Journal of Materials Research, v. 12, no. 8, pp. 1946-1975.

Wu, H.F., Lin, C.C., and Shen, P.Y. (1997), Structure and dissolution of CaO- $\mathrm{ZrO}_{2}-\mathrm{TiO}_{2}-\mathrm{Al}_{2} \mathrm{O}_{3}-\mathrm{B}_{2} \mathrm{O}_{3}-$ $\mathrm{SiO}_{2}$ glass (II). Journal of Non-crystalline Solids, v. 209, pp. 76-86. 


\title{
- Chapter 5 -
}

\section{ISOTOPIC INVESTIGATION OF RECHARGE TO A REGIONAL GROUNDWATER FLOW SYSTEM, GREAT BASIN, NEVADA, USA}

\author{
Timothy P. Rose, M. Lee Davisson, Robert E. Criss ${ }^{1}$, and David K. Smith \\ ${ }^{1}$ Department of Earth and Planetary Sciences, Washington University, St. Louis, MO
}

This report will also be published in the Proceedings of the International Symposium on Isotope Techniques in Water Resources Development and Management, sponsored by the International Atomic Energy Agency, Vienna, 10-14 May 1999.

\section{Summary}

Groundwater recharge processes were investigated in central Nevada by examining the relationships between the stable isotope $\left(\delta \mathrm{D}\right.$ and $\left.\delta^{18} \mathrm{O}\right)$ compositions of snowfall, snowmelt, alpine spring waters, and regional groundwaters. Snowmelt infiltration is inferred to be the dominant source of groundwater recharge in this region. Bulk snow cores collected throughout central Nevada near the time of maximum accumulation have $\delta \mathrm{D}-\delta^{18} \mathrm{O}$ pairs that plot subparallel to the global meteoric water line (GMWL), but are shifted to the right of the line, implying kinetic isotope enrichments. Heavy isotope enrichments occur at the base of snowpacks due to fractionation during snow metamorphism, sometimes resulting in remarkably systematic isotopic variations. Ice crystals in the soil immediately beneath the snowpack can be strongly depleted in heavy isotopes relative to the overlying snow, implying fractionation or exchange with the snowpack. Late season ablation processes tend to homogenize isotopic variations between snowpack layers, and cause the bulk isotopic composition of the snowpack to become enriched in ${ }^{18} \mathrm{O}$ by $2-3 \%$ relative to the composition during peak accumulation. The dynamic evolution of the snowpack and snowmelt isotopic compositions over time makes it difficult to directly ascertain groundwater recharge compositions without careful mass balance measurements. Preliminary evidence suggests that small local springs may be reasonable indicators of the integrated isotopic value of the snowmelt recharge in a particular area. Springs and snowmelt runoff samples collected throughout central Nevada during the peak runoff plot along a least squares regression line with the equation $\delta \mathrm{D}=7.3 \delta^{18} \mathrm{O}-7$, which is similar to the line obtained for 28 metamorphosed snow cores collected during peak accumulation $\left(\delta \mathrm{D}=7.5 \delta^{18} \mathrm{O}-3\right)$. These results suggest that kinetic fractionation processes during snow metamorphism and ablation may largely account for the heavy isotope enrichments that are widely observed in groundwaters from both local and regional flow systems in Nevada.

\section{Introduction}

The state of Nevada receives the lowest annual amount of precipitation of the 50 United States, but currently has the highest rate of population growth. The lack of reliable surface water supplies in Nevada implies that future development will depend 


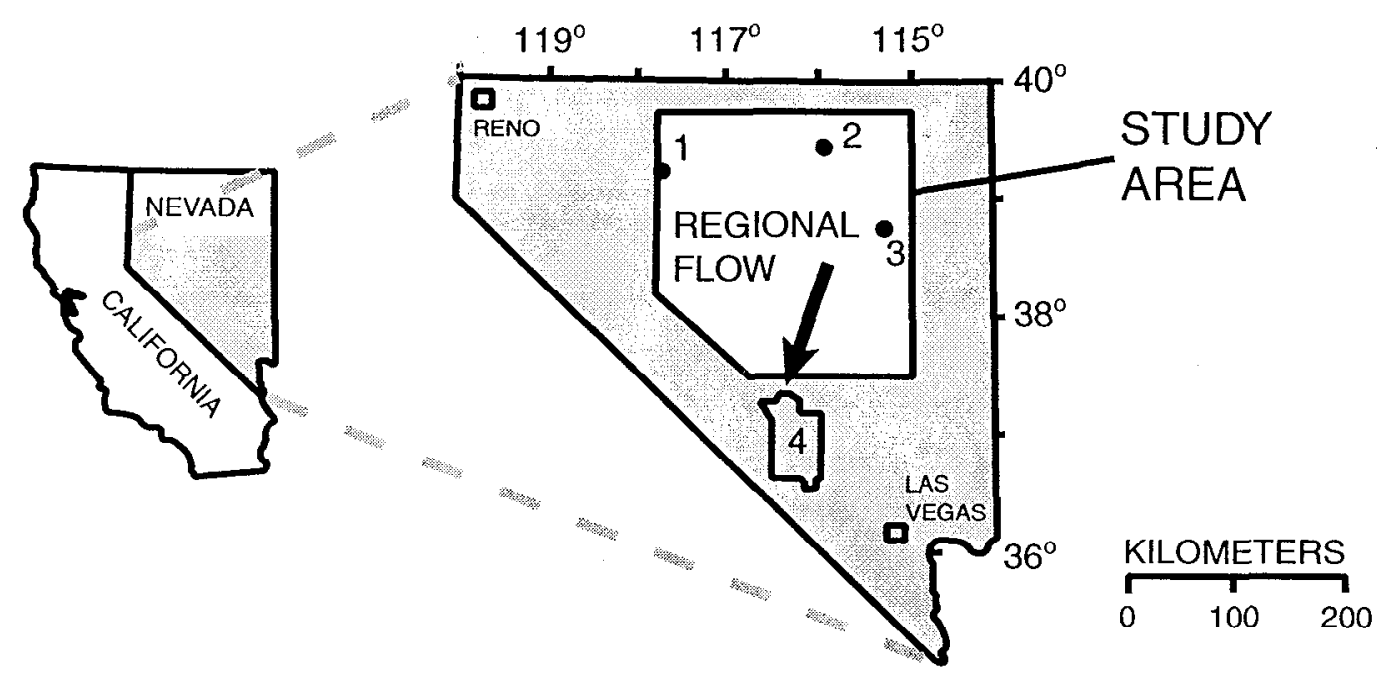

Figure 1: Location of study area. Numbered features correspond to locations discussed in the text: (1) Carroll Summit; (2) Pinto Summit; (3) Currant Summit; (4) Nevada Test Site.

largely on the extraction of deep groundwater from desert basins. For this reason, it is of vital interest to develop an understanding of the sources and mechanisms for groundwater recharge in this region. Summer convective storms account for approximately one third of the annual precipitation in central and southern Nevada. However, these storms are typically of short duration and limited areal extent. High evapotranspiration rates during the summer coupled with long infiltration pathways to the water table generally limit summer recharge contributions. In contrast, winter frontal systems normally deposit more than half of the annual precipitation as snowfall, producing relatively large accumulations in alpine areas. The alpine snowpacks are rapidly melted in the spring and early summer, accounting for a majority of the annual groundwater recharge budget. A recent study (Winograd et al., 1998) comparing the stable isotope signatures of spring water and precipitation in the mountains near Las Vegas, Nevada concluded that spring snowmelt accounts for up to $90 \%$ of all groundwater recharge in this region. A comparable study in Arizona drew similar conclusions regarding the importance of recharge from snowmelt (Simpson et al., 1972).

This paper discusses the results of a regional survey of the stable isotope compositions of winter snowpacks in central Nevada. The study area is inferred to be the principal recharge center for a regional aquifer system that extends $>200 \mathrm{~km}$ from mountainous regions in central Nevada to the low desert along the Nevada-California border (Fig. 1). We focus in this report on (1) understanding the processes that influence the isotopic composition of the snowpack over time; (2) comparing the $\delta \mathrm{D}$ and $\delta^{18} \mathrm{O}$ compositions of the snowpack with those of alpine spring waters, snowmelt 
runoff and regional groundwaters; and (3) relating the observed heavy. isotope enrichments (relative to the GMWL) in groundwaters to processes that occur during snow metamorphism and ablation.

\section{Hydrogeologic Setting}

The Great Basin province encompasses a $360,000 \mathrm{~km}^{2}$ area, largely in Nevada and western Utah, characterized by subparallel north-south trending mountain ranges separated by alluvial and fluviolacustrine basins (Harrill et al., 1988). The arid nature of this hydrologically closed basin is largely a result of the rain shadow effect of the Sierra Nevada range, which inhibits the prevailing westerly winds from carrying large amounts of moisture inland from the Pacific Ocean. Regional groundwater flow systems of the Great Basin are typified by fracture-dominated flow through thick sequences of carbonate and volcanic rocks, driven by hydraulic gradients that are laterally continuous over hundreds of kilometers (Harrill et al., 1998; Winograd \& Thordarson, 1975; Thomas et al., 1996). Davisson et al. (1999) observed that these regional flow systems are characterized by systematic increases in $\delta^{18} \mathrm{O}$ values with decreasing latitude, in the direction of southward regional flow. The increase in $\delta^{18} \mathrm{O}$ along the flow path was interpreted to indicate gradual mixing with ${ }^{18} \mathrm{O}$-enriched recharge at progressively lower latitudes. At latitudes south of $\sim 38^{\circ} \mathrm{N}$, annual precipitation rates in Nevada are low (generally $<25 \mathrm{~cm} \mathrm{yr}^{1}$ ) and regional groundwaters typically have $\delta^{18} \mathrm{O}$ values that are 2-3\%o depleted in heavy isotopes relative to local recharge. Most regional groundwaters also exhibit low deuterium excess values ( $d$-values between +1 and +6$)$ and are shifted to the right of the global meteoric water line (GMWL; $\delta \mathrm{D}=8 \delta^{18} \mathrm{O}+10$ ) (Craig, 1961). The $d$-values discussed here refer to single data points in $\delta$-space, according to the definition $d=\delta \mathrm{D}-8 \delta^{18} \mathrm{O}$ (Dansgaard, 1964). The low $d$-values, coupled with the conspicuous difference between the stable isotope values of deep groundwater and local precipitation, led several researchers to conclude that the isotopically-depleted groundwaters in southern Nevada were locally recharged under cooler paleoclimatic conditions (e.g., Claassen, 1986; Benson \& Klieforth, 1989).

From a practical standpoint, determining the relative abundance of recharge from these different sources is a critical issue with regard to interpreting groundwater flow patterns through the U.S. Department of Energy's Nevada Test Site (NTS). The NTS was the location for more than 800 underground nuclear tests conducted by the United States between 1951 and 1992 (United States Department of Encrgy, 1994). The recent discovery of colloidal transport of actinides in NTS groundwater (Kersting et al., 1999) has underscored the need for a more comprehensive understanding of the flow system in this region. For this reason, a research program has been initiated to evaluate recharge processes and flowpaths related to regional groundwater flow. Precipitation patterns in Nevada suggest that most of the significant recharge to the regional flow system occurs between latitudes 38 and $40^{\circ} \mathrm{N}$, primarily in alpine areas 
that may receive over $50 \mathrm{~cm} \mathrm{yr}^{-1}$ of precipitation (Lamke \& Moore, 1965). A majority of this precipitation occurs during the winter months as snowfall.

\section{Stable Isotope Variations in Snow Packs}

Snow core samples were collected at 28 locations over a broad region of central Nevada (latitude $37^{\circ} 30^{\prime}$ to $39^{\circ} 45^{\prime} \mathrm{N}$; longitude $115^{\circ}$ to $117^{\circ} 45^{\prime} \mathrm{W}$ ) during early March 1998, and from selected locations in late April 1998 and early March 1999. The 1997-1998 winter season was characterized by a strong El Niño-Southern Oscillation influence that produced heavier than average precipitation rates in Nevada (Harrison \& Larkin, 1998). In contrast, winter storms were less frequent during the 1998-1999 season, and snowpack depths measured in March 1999 were typically less than half that of the 1997-1998 season.

Isotope effects during snow metamorphism

At the time of peak accumulation (March), most Nevada snowpacks showed physical evidence of snow metamorphism, such as the development of depth hoar and grain clusters (Colbeck, 1987). Heat transfer from the ground to the overlying snowpack creates both temperature and vapor pressure gradients within the snowpack (Benson \& Trabant, 1973). Under these conditions, mass transport and recrystallization processes are accompanied by isotopic fractionation effects (Friedman, 1991) that can attenuate the initial isotopic variability of individual snow layers (Judy, 1970). Recrystallization was especially pronounced in samples collected below 2,000 meters elevation, where the snowpacks tended to be thinner.

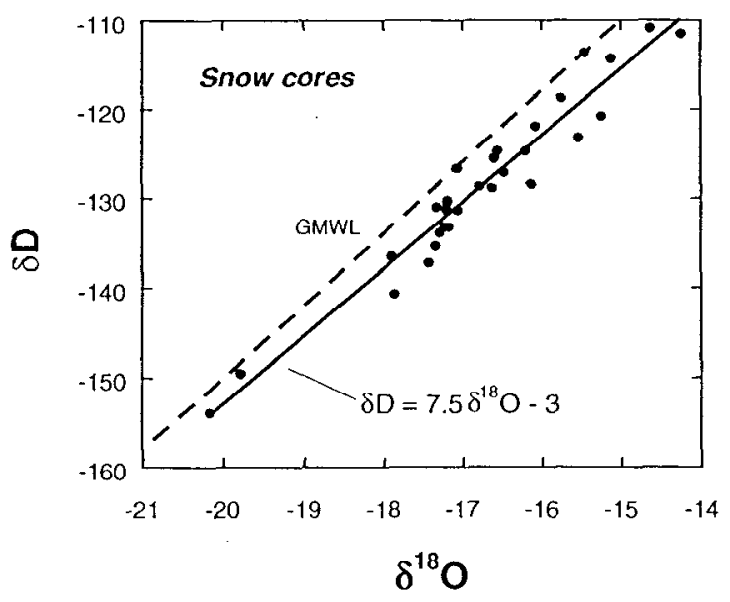

Figure 2: Plot of $\delta \mathrm{D}-\delta^{18} \mathrm{O}$ pairs for snow core samples collected in central Nevada, March 1998. 
The least-squares regression line for 28 bulk snow cores collected in March 1998 is $\delta \mathrm{D}=7.5 \delta^{18} \mathrm{O}-3$ (Fig. 2). Many of these data points are shifted to the right of the GMWL, indicating the relative significance of kinetic isotope fractionation effects during aging of the snowpack. The effects of snow metamorphism are well illustrated by the isotopic results for the Currant Summit snowpack $\left(38^{\circ} 49^{\prime} \mathrm{N}, 115^{\circ} 17^{\prime} \mathrm{W}\right.$, elevation 2,130 m) sampled in March 1999 (Fig. 3). The $\delta^{18} \mathrm{O}$ values of individual layers decrease systematically from $-11 \%$ at the base to $-18 \%$ at $19 \mathrm{~cm}$ above the base, then abruptly shift toward isotopically heavier values in the top $4 \mathrm{~cm}$ of the snowpack (Fig. 3a). On a plot of $\delta^{18} \mathrm{O}$ versus $\delta \mathrm{D}$ (Fig. 3b), samples from the base of the snowpack are enriched in both $\delta^{18} \mathrm{O}$ and $\delta \mathrm{D}$ and lie along a slope of 3.8 , whereas samples from the upper part of the snowpack plot relatively close to the GMWL.

Isotopic enrichment effects associated with snowpack aging and depth hoar formation have been widely documented (e.g., Epstein et al., 1991; Moser \& Stichler, 1970; Martinec, 1977). Friedman et al. (1991) suggested that isotopic fractionation during snow metamorphism is related to two processes: the change of state from solid to vapor, and molecular diffusion during vapor transport. The fractional condensation of water vapor derived from sublimation onto growing snow crystals favors enrichment in the molecules with the lowest vapor pressure (i.e. the heavier molecules), possibly resulting in $\delta \mathrm{D}-\delta^{18} \mathrm{O}$ slopes $>8$ when this process is dominant (Friedman, et al., 1991). In contrast, molecular diffusion during simple loss of water vapor will result in kinetic fractionations with low slope $\delta \mathrm{D}-\delta^{18} \mathrm{O}$ trajectories near 2 . The results in Fig. 3 suggest these fractionation processes operate simultaneously, and that one process may dominate over the other in different parts of the snowpack. The presence of a
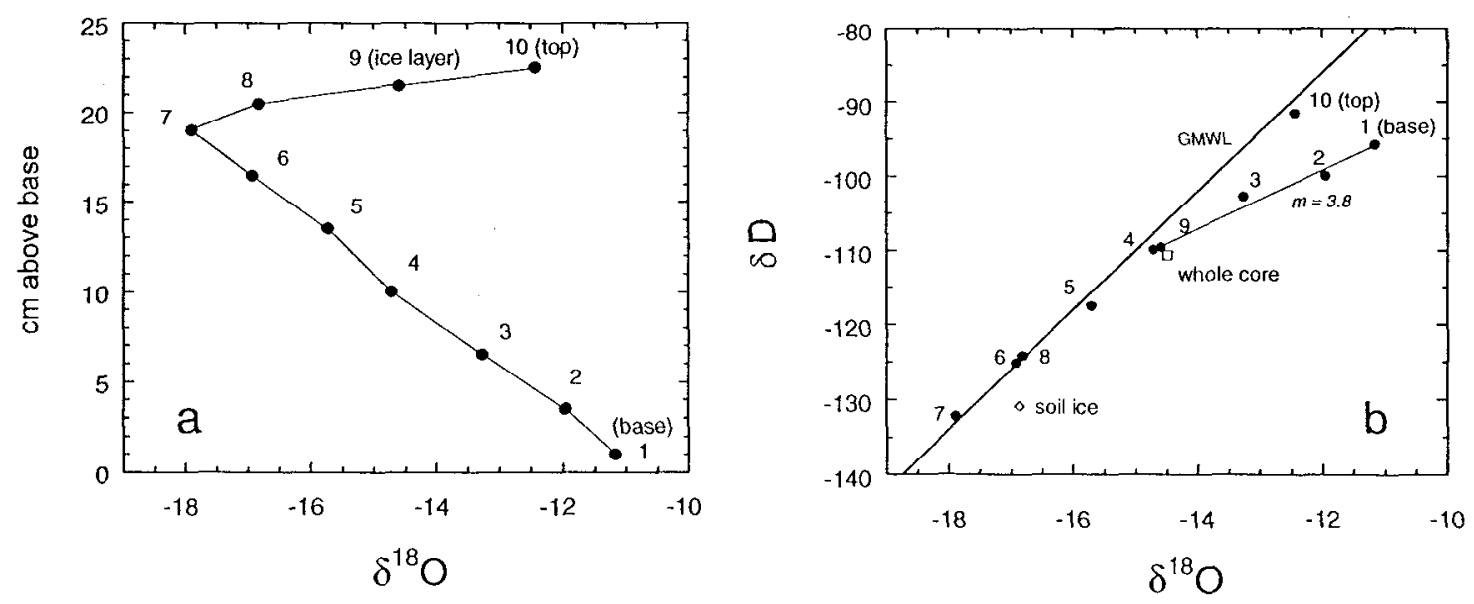

Figure 3: Stable isotope data for Currant Summit snowpack, March 1999: (a) variation in $\delta{ }^{18} \mathrm{O}$ with stratigraphic position; (b) plot of $\delta \mathrm{D}$ versus $\delta{ }^{18} \mathrm{O}$ values. 
dense ice layer near the top of the Currant Summit snowpack (Fig. 3a) probably reflects partial melting and re-freezing from solar heating, or possibly a rain-on-snow event. If this ice layer created a barrier to atmospheric vapor exchange, it may help to explain the remarkably systematic isotopic variations observed in the lower part of the snowpack.

It is notable that ice crystals collected from the soil immediately beneath the snowpack are nearly $6 \%$ depleted in $\delta^{18} \mathrm{O}$ relative to the basal snow layer (Fig. 3b). This effect was also observed at other locations. Friedman et al. (1991) demonstrated that the transfer of water from the soil to the base of the snowpack plays a part in enriching the snow in heavy isotopes. Our results indicate that the moisture remaining in the upper soil zone is isotopically fractionated during this process, or that the upper soil zone exchanges vapor with the base of the snowpack.

Isotope effects during snowpack melting

To investigate snowpack aging over time, five of the high elevation locations $(2,100-$ 2,300 m) that were sampled in March 1998 were revisited during an intense melting period in late April 1998. Whereas the March snowpacks showed up to 5\%o variations in $\delta^{18} \mathrm{O}$ between different layers, the variations in the April snowpacks were frequently less than $2 \%$. This homogenization of the snowpack probably reflects interactions between the percolating meltwater and snow (Arnason et al., 1973; Stichler et al., 1981). It was found that the top of the April snowpack was often slightly enriched in heavy isotopes relative to the base. This is in contrast to the March snowpack, when the base invariably had the heaviest isotopic values. The fractionation of stable isotopes between coexisting water and ice favors enrichment of the solid phase in heavy isotopes (O'Neil, 1968). Given that snowpack ablation proceeds from the top downward, the isotopic enrichment at the top of the snowpack may in part reflect the preferential removal of light isotopes in the liquid phase during melting.

In general, the integrated (bulk) isotopic values for the April snowpacks were 2 to $3 \%$ o heavier in $\delta^{18} \mathrm{O}$ relative to their March counterparts. This enrichment process follows a $\delta \mathrm{D}-\delta^{18} \mathrm{O}$ trajectory with a slope that varies between 7 and 10 . The observed isotopic enrichment in the residual snowpack must therefore be balanced by prior losses of light isotopes. It has been previously demonstrated that the light isotopes predominate in the initial stages of runoff, whereas the heavy isotope content of the runoff steadily increases with time (Stichler et al., 1981; Herrmann et al., 1981).

\section{Stable Isotope Variations In Surface Runoff And Groundwater}

\section{Isotope relationships between melting snow, local springs and runoff}

During the April 1998 melting event, particular attention was given to obtaining samples of snowmelt runoff and spring water near the snowpack sampling locations. The objective was to determine the extent to which the meltwater inherits kinetic 
isotope enrichments from snow metamorphism and ablation. The $\delta \mathrm{D}-\delta^{18} \mathrm{O}$ results from two different sample locations are shown in Fig. 4. At Carroll Summit $\left(39^{\circ} 16^{\prime} \mathrm{N}, 117^{\circ} 44^{\prime} \mathrm{W}\right.$, elevation $\left.2,270 \mathrm{~m}\right)$, the bulk composition of the snowpack evolved along a $\delta \mathrm{D}-\delta^{18} \mathrm{O}$ slope of 8.7 between March and April 1998 (Fig. 4a). Samples of snowmelt runoff, spring discharge and soil water collected in April are all shifted to the right of the GMWL relative to the snowpack, but plot on a colinear trend with a slope of near 8 . This implies that each sample experienced a similar degree of kinetic isotopic enrichment.

The soil water sample from Carroll Summit was obtained by coring the upper $5 \mathrm{~cm}$ of water-saturated bare ground directly adjacent to the melting snowpack (Fig. 4a). The close proximity of the soil sample to the melting snowfield suggests the moisture was derived from recent snowmelt cannot rule out the possibility of an "older" groundwater component in the runoff and spring samples. However, the spring lies within $20 \mathrm{~m}$ of the summit elevation, and its cphemcral (scasonal) nature suggests that most of the discharge is probably related to recent infiltration.

Fig. $4 \mathrm{~b}$ shows a $\delta \mathrm{D}-\delta^{18} \mathrm{O}$ plot for the March and April 1998 snow cores and two different springs from the Pinto Summit area $\left(39^{\circ} 27^{\prime} \mathrm{N} 115^{\circ} 56^{\circ} \mathrm{W}\right.$, elevation $\left.2,250 \mathrm{~m}\right)$
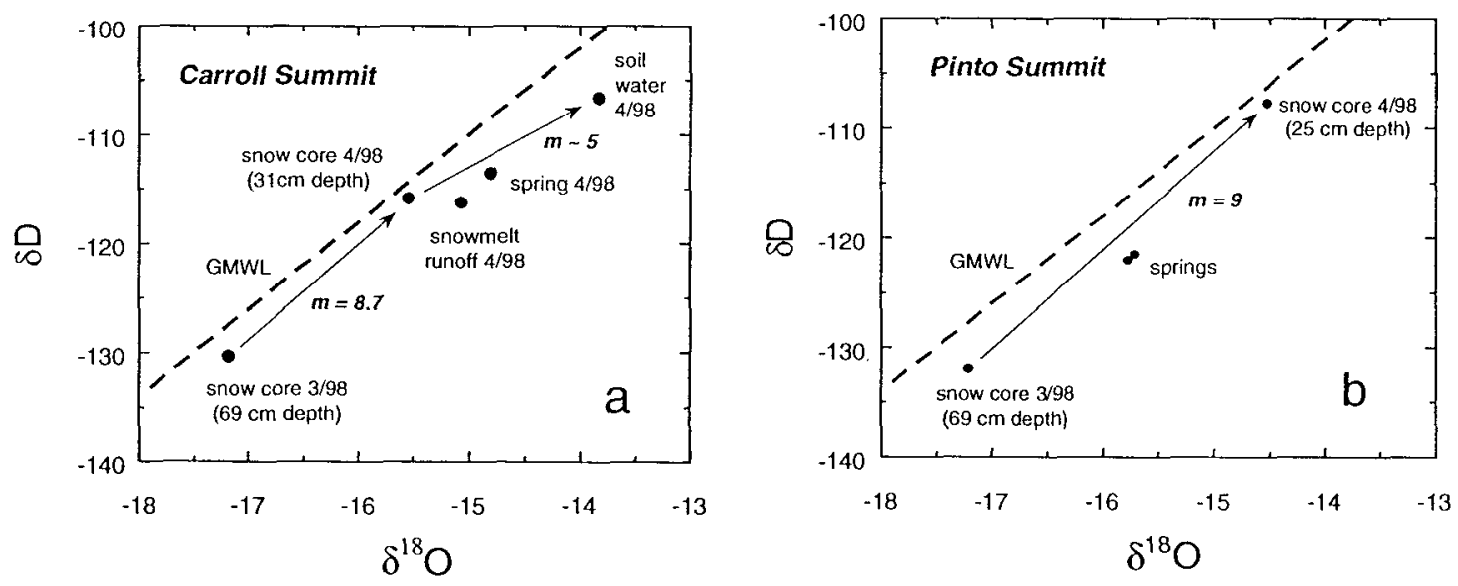

Figure 4: Temporal variations in snowpack $\delta \mathrm{D}$ and $\delta{ }^{18} \mathrm{O}$ values compared to local meltwater and spring water isotope values: (a) Carroll Summit; (b) Pinto Summit.

In this case, the snow core collected in March 1998 had a bulk isotopic value that was isotopically depleted relative to nearby springs, whereas the April 1998 snowpack was enriched relative to the springs. The spring waters were sampled during two different years, and from two different springs, yet they have remarkably similar isotopic values. Similar relationships were observed at other locations. These results suggest that small local springs may be the best indicators of the integrated recharge 
isotopic value in a particular location, particularly given the dynamic evolution of the snowpack isotopic composition with time.

\section{Regional implications for snowmelt recharge}

Alpine springs and snowmelt-derived runoff collected from high elevation ranges throughout central Nevada (north of $38^{\circ}$ latitude) plot along a least-squares regression line with the equation $\delta \mathrm{D}=7.3 \delta^{18} \mathrm{O}-7$ (Fig. 5). All of the spring water and runoff samples were collected in April or early May, during the peak period of snowmelt. It is noteworthy that the spring water/runoff regression line is similar to the line obtained for the 28 snow core samples collected in March $1998\left(\delta \mathrm{D}=7.5 \delta^{18} \mathrm{O}-3\right)$ (Fig. 2). This result suggests that kinetic fractionation processes occurring during snow metamorphism and ablation may largely account for the heavy isotope enrich-

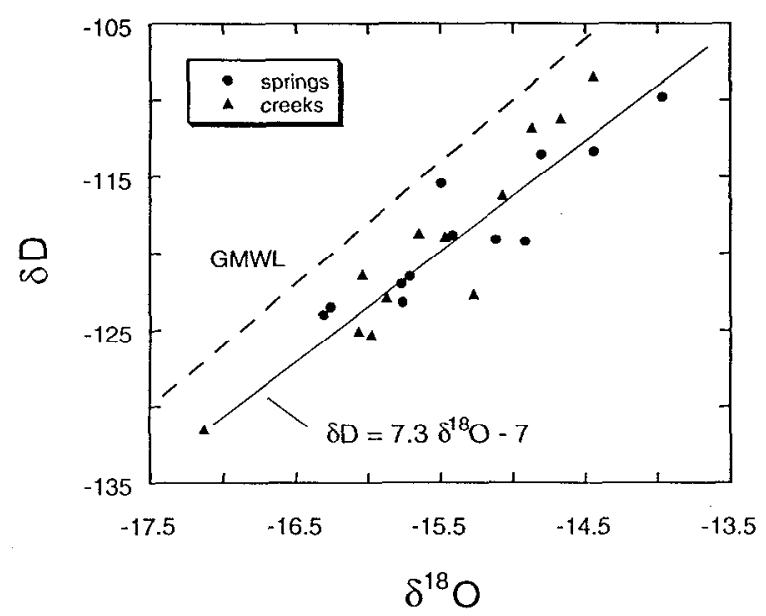

Figure 5: Plot of $\delta \mathrm{D}-\delta{ }^{18} \mathrm{O}$ pairs for alpine springs and snowmelt runoff in central Nevada.

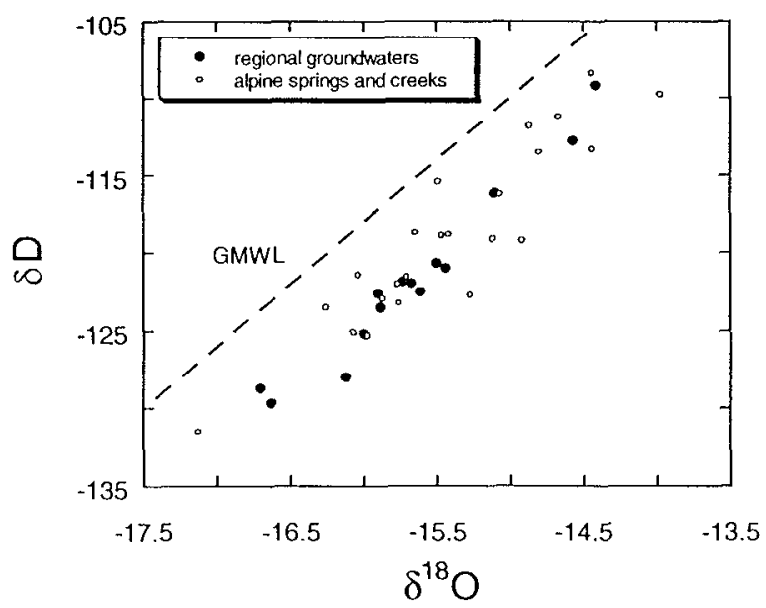

Figure 6: Plot of $\delta \mathrm{D}-\delta^{18} \mathrm{O}$ pairs for central Nevada regional groundwaters, compared to alpine springs and snowmelt runoff from the same region. 
ments and low $d$-values observed in Nevada groundwaters. Lastly, it is of interest to compare the $\delta \mathrm{D}-\delta^{18} \mathrm{O}$ compositions of the alpine springs and runoff with those of groundwater from regional aquifers underlying the central Nevada basins (Fig. 6). All of the regional groundwaters (shown as solid circles in Fig. 6) were sampled from springs, most of which originate from the regional carbonate aquifer and have warm temperatures indicative of a deep flowpath history. The regional groundwaters exhibit a shift to the right of the GMWL that is comparable to that of the alpine springs and creeks from which they are inferred to be derived (Fig. 6). The regional groundwaters typically exhibit $\delta^{18} \mathrm{O}$ values that are 0.2 to $0.4 \%$ lower than alpine springs from adjacent ranges in central Nevada. However, this is interpreted to show that the recharge is predominantly derived from the highest elevation parts of the ranges (up to $3,500 \mathrm{~m}$ ), which also receive the highest amounts of winter snowfall.

To summarize, the results of this study indicate that regional groundwater flow systems in central Nevada are locally recharged, and that much of this recharge is derived from melting of the winter snowpack. The apparent link between this recharge area and regional groundwater transport into southern Nevada (Davisson et al., 1999) suggests the heavy isotope enrichments and low $d$-values previously attributed to recharge under paleoclimatic conditions in southern Nevada may be simply related to processes occurring during modern recharge.

\section{Acknowledgements}

Funding for this project was provided by the Hydrologic Resources Management Program of the U.S. Department of Energy, Nevada Operations Office (DOE/NV). In particular, we thank Bonnie Thompson and Doug Duncan of DOE/NV for their continuing support of this work. Gail Eaton assisted with field work, and with figure preparation for this manuscript.

\section{References}

Arnason, B., et al. (1973) Movement of water through snow pack traced by deuterium and tritium, in: The Role of Snow and Ice in Hydrology (Symposium Proceedings, Banff, 1972), Unesco-WMOIAHS Publication no. 107, Geneva, pp. 299-312.

Benson, L.V., Klieforth, H. (1989) Stable isotopes in precipitation and groundwater in the Yucca Mountain region, southern Nevada: paleoclimatic implications, in: Aspects of Climate Variability in the Pacific and Western Americas (Peterson, D.H., Ed.), American Geophysical Union, Geophysical Monograph Series, n. 55, AGU, Washington D.C., pp. 41-59.

Benson, C.S., Trabant, D.C. (1973) Field measurements on the flux of water vapour through dry snow, in: The Role of Snow and Ice in Hydrology (Symposium Proceedings, Banff, 1972). UnescoWMO-IAHS Publication no. 107, Geneva, pp. 291-298.

Claassen, H.C. (1986) Late-Wisconsin paleohydrology of the west-central Amargosa Desert, Nevada, USA. Chemical Geology, v. 58, p. 311-323. 
Colbeck, S.C. (1987) Snow metamorphism and classification, in: Seasonal Snowcovers: Physics, Chemistry, Hydrology (Jones, H.G., Orville-Thomas, W.J., Eds.). NATO ASI Series C, Mathematical and Physical Sciences no. 211, Reidel, Dordrecht, pp. 1-35.

Craig, H. (1961) Isotopic variations in meteoric waters, Science, v. 133, p. 1702-1703.

Dansgaard, W. (1964) Stable isotopes in precipitation, Tellus, v. 16, p. 436-468.

Davisson, M.L., et al. (1999) Isotope hydrology of southern Nevada groundwater: stable isotopes and radiocarbon. Water Resources Research, v. 35, p. 279-294.

Epstein, S., et al. (1965) Six-year record of oxygen and hydrogen isotope variations in South Pole firn. J. Geophysical Research, v. 70, p. 1809-1814.

Friedman, I., et al. (1991) Isotopic changes during snow metamorphism, in: Stable Isotope Geochemistry: A Tribute to Samuel Epstein (Taylor, H.P., Jr., et al., Eds.), The Geochemical Society, Special Publication no. 3, San Antonio, Texas (1991) pp. 211-221.

Harrill, J.R., et al. (1998) Major ground-water flow systems in the Great Basin region of Nevada, Utah, and adjacent states, U.S. Geological Survey, Hydrologic Investigations Atlas HA-694-C, 1:1,000,000 scale, USGS, Reston, Virginia, 2 sheets.

Harrison, D.E., Larkin, N.K. (1998) Seasonal U.S. temperature and precipitation anomalies associated with El Niño: Historical results and comparison with 1997-98. Geophysical Research Letters, v. 25 , p. $3959-3962$.

Herrmann, A., et al. (1981) Isotope input into runoff systems from melting snow covers. Nordic Hydrology, v. 12, p. 309-318.

Judy, C., et al. (1970) Deuterium variations in an annual snowpack, Water Resources Research, v. 6, p. 125-129.

Kersting, A.B., et al. (1999) Migration of plutonium in ground water at the Nevada Test Site. Nature, v. 397, p. $56-59$.

Lamke, R.D., Moore, D.O. (1965) Interim inventory of surface water resources of Nevada. Nevada Department of Conservation and Natural Resources, Water Resources Bulletin 30, Carson City, Nevada, $38 \mathrm{p}$.

Martinec, J., et al. (1977) Assessment of processes in the snowpack by parallel deuterium, tritium and oxygen-18 sampling, in: Isotopes and Impurities in Snow and Ice (Symposium Proceedings, Grenoble, 1975), IAHS-AISH Publication no. 118, Paris, pp. 220-231.

Moser, H., Stichler, W. (1970) Deuterium measurements on snow samples from the Alps, in: Isotope IIydrology (Symposium Proceedings, Vienna, 1970), IALA, Vienna, pp. 43-57.

O'Neil, J.R. (1968) Ifydrogen and oxygen isotope fractionation between ice and water. Journal Physical Chemistry, v. 72, p. 3683-3684.

Simpson, E.S., et al. (1972) Distinguishing seasonal recharge to groundwater by deuterium analysis in southern Arizona, in: World Water Balance (Symposium Proceedings, Reading, 1970), IASHUnesco Publication No. 92, Gentbrugge, Belgium, p. 623-633. 
Stichler, W., et al. (1981) Environmental isotope studies of an Alpine snowpack. Nordic Hydrol., v. 12, p. 297-308.

Thomas, J.M., et al. (1996) Geochemistry and isotope hydrology of representative aquifers in the Great Basin region of Nevada, Utah, and adjacent states. U.S. Geological Survey, Professional Paper 1409-C, USGS, Reston, Virginia $100 \mathrm{p}$.

United States Department of Energy (1994) United States Nuclear Tests, July 1945 through September 1992, U.S. Department of Energy, Nevada Operations Office, DOE/NV-209 (Rev. 14), U.S. Government Printing Office, Washington D.C., 38 p.

Winograd, I.J., et al. (1998) The relative contributions of summer and cool-season precipitation to groundwater recharge, Spring Mountains, Nevada, USA. Hydrogeology Journal, v. 6, p. 77-93.

Winograd, I.J., and Thordarson, W., (1975) Hydrogeologic and hydrochemical framework, southcentral Great Basin, Nevada-California, with special reference to the Nevada Test Site, U.S. Geological Survey, Professional Paper 712-C, USGS, Reston, Virginia 126 p. 


\title{
- Chapter 6 -
}

\section{Stable Isotope and Radiocarbon Compositions of Secondary Calcite from Pahute Mesa, Nevada Test Site}

\author{
Timothy P. Rose, F. Christopher Benedict, Jr. ${ }^{1}$, and Gail F. Eaton \\ ${ }^{1}$ HSI-Geotrans, 50 West Liberty, Suite 580, Reno, NV 89501
}

\section{Summary}

Secondary calcite samples were obtained from archived core and cuttings samples from six different wells on Pahute Mesa and analyzed for their $\delta^{13} \mathrm{C}, \delta^{18} \mathrm{O}$ and ${ }^{14} \mathrm{C}$ values. In the unsaturated zone, calcite was deposited by downward percolation of meteoric water at low to moderate temperatures. Most of the unsaturated zone calcites have $\delta^{13} \mathrm{C}$ values that reflect a pedogenic (soil zone) source, although two samples have unusually high $\delta^{13} \mathrm{C}$ values derived from microbial decomposition of organic matter. In contrast, saturated zone calcites were deposited by regional groundwater, and have $\delta^{13} \mathrm{C}$ signatures derived from Paleozoic rocks that underlie the volcanic section. Most of the saturated zone samples have $\delta^{18} \mathrm{O}$ values that reflect deposition from hydrothermal fluids at temperatures as high as $170^{\circ} \mathrm{C}$. The variation in $\delta^{18} \mathrm{O}$ with depth indicates paleogeothermal gradients between 45 and $70^{\circ} \mathrm{C} / \mathrm{km}$ for many samples, and as high as $135^{\circ} \mathrm{C} / \mathrm{km}$ for a few samples. These results suggest calcite deposition occurred during or shortly after periods of active volcanism in this area. The high geothermal gradients that were present during calcite deposition no longer exist in the modern environment beneath Pahute Mesa. Radiocarbon measurements on ten different samples revealed that most of the calcite is older than the age resolution of the ${ }^{14} \mathrm{C}$ dating method ( $>42,500$ years). One sample has a ${ }^{14} \mathrm{C}$ activity of 0.83 percent modern carbon, yielding a 38,500 year age. Absolute ages are unknown for the remaining samples. Calcite isotopic values can be correlated to hydrostratigraphic intervals to provide information for modeling calcite interaction with modern groundwater. Under current water level conditions, calcite from the shallow saturated zone shows a range in $\delta^{13} \mathrm{C}$ values reflecting deposition under both saturated and unsaturated conditions. In deeper aquifer units, calcite samples have $\delta^{13} \mathrm{C}$ signatures derived from Paleozoic carbonate rocks. One sample from highly fractured rock in the deep saturated zone has a $\delta^{18} \mathrm{O}$ value that indicates deposition from deep circulation of modern groundwater. 


\section{Introduction}

This report summarizes the results of an isotopic investigation of calcite mineralization in drill core samples from Pahute Mesa, Nevada. A companion report (IT Corporation, 1998) discusses the results of a micrographic investigation of these samples. 'This work is in support of a larger multi-agency effort to evaluate regional groundwater flow paths and transport rates between Pahute Mesa and Oasis Valley, in southwestern Nevada. The nature of this flow system is of considerable importance due to the relatively short distance $(\sim 30 \mathrm{~km})$ between underground nuclear testing areas on Pahute Mesa and nearby groundwater discharge areas. The multi-agency investigation includes collaborators from the U.S. Geological Survey, Desert Research Institute, HSI-Geotrans and Lawrence Livermore National Laboratory, and is funded by the Underground Test Area (UGTA) Operable Unit for the U.S. Department of Energy, Nevada Operations Office.

Geochemical investigations of the Oasis Valley flow system are focused on developing an environmental chemical and isotopic database that can be used to constrain numerical groundwater flow modeling efforts (DOE, 1997). Groundwater age constraints are provided in part by radiocarbon $\left({ }^{14} \mathrm{C}\right)$ measurements of dissolved inorganic carbon. One drawback to the ${ }^{14} \mathrm{C}$ dating method is that dissolved inorganic carbon can react with minerals in the aquifer, thereby modifying the ${ }^{14} \mathrm{C}$ age recorded by the groundwater. Calcite veins and fracture fillings in the volcanic aquifers on Pahute Mesa represent one potential source of exchangeable carbon. It is therefore of interest to examine the occurrence and isotopic composition of secondary calcite from Pahute Mesa in order to provide constraints for groundwater modeling efforts.

Calcite samples were obtained from archived drill core in the U.S. Geological Survey Core Library at the Nevada Test Site. Approximately 20 samples were selected from core representing 6 different wells. Well locations are shown in Figure 1. The cores that were examined were pre-selected on the basis of available lithologic logs. When secondary calcite was indicated in the logs, these intervals were noted and subsequently examined at the Core Library. Sometimes calcite was not present in the indicated interval, although examination of other boxes of core revealed that calcite was more widespread than previously indicated. A more thorough examination of core samples from other wells may reveal the presence of additional secondary calcite that is not presently noted in existing lithologic logs. 


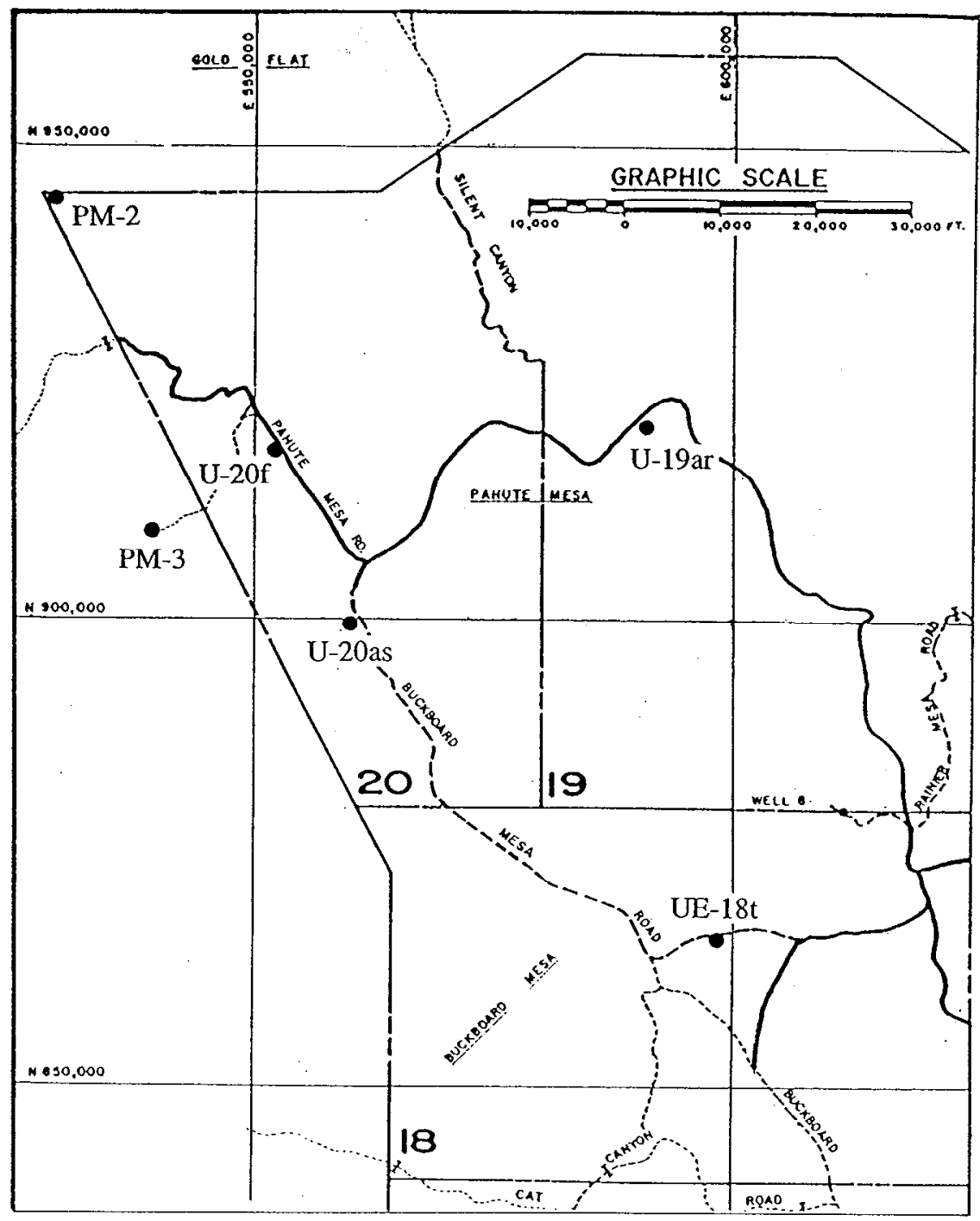

Figure 1. Map of the northwestern Nevada Test Site showing locations of drill holes from which calcite samples were obtained from archived drill core.

This report provides brief descriptions of the calcite samples acquired for this study, together with the results of stable isotope $\left({ }^{13} \mathrm{C} /{ }^{12} \mathrm{C}\right.$ and $\left.{ }^{18} \mathrm{O} /{ }^{16} \mathrm{O}\right)$ and ${ }^{14} \mathrm{C}$ analyses. A detailed description their petrologic occurrence is found in a report published by the IT Corporation (1998). The isotopic data summarized here are useful for evaluating the origin of the calcite, and for assessing water-rock interaction processes that influence groundwater ages. 


\section{Methods}

Calcite veins and fracture coatings were separated from the host rock using dental tools and picks. Calcite was ground in a mortar and pestle, sieved to $-100 /+150$ mesh size, washed in deionized water and acetone, and dried in a convection oven at $80^{\circ} \mathrm{C}$. In some samples, the calcite was dispersed as microcrystalline cement throughout the rock matrix. Under these circumstances, the entire sample was crushed, sieved and washed. Detailed analysis of selected layers of vein material typically involved the careful removal of calcite with a carbide dental bur mounted on a small rotary drill. Samples prepared in this manner were very fine grained, and were not washed prior to analysis.

Analytical methods follow procedures outlined in the Standard Operating Procedures for the UGTA project (ISD, 1995). Calcite samples were reacted with 100\% phosphoric acid at $25^{\circ} \mathrm{C}$ (McCrea, 1950) and the resulting $\mathrm{CO}_{2}$ gas was purified and split into aliquots for stable isotope and radiocarbon analysis. Carbon and oxygen stable isotope ratios were measured on a VG Prism mass spectrometer. Results are reported using the conventional $\delta$ notation relative to the PDB (carbon) and SMOW (oxygen) standards. Isotope ratios were calibrated using the following NBS calcite reference standards (Coplen et al., 1983; Reed, 1992):

$\begin{array}{lcc} & \delta^{13} \mathrm{C}(\% \circ \mathrm{PDB}) & \delta^{18} \mathrm{O}(\% \circ \text { SMOW }) \\ \text { NBS-18 } & -5.04 & +7.16 \\ \text { NBS-19 } & +1.95 & +28.65 \\ \text { NBS-20 } & -1.06 & +26.64\end{array}$

Reproducibility on the reference standards was better than \pm 0.1 per mil for carbon and \pm 0.15 per mil for oxygen (Table 1). Duplicate preparation and analysis of five unknowns yielded similar reproducibility for most samples. Somewhat higher standard deviations on one $\delta^{13} \mathrm{C}$ and two $\delta^{18} \mathrm{O}$ replicates may reflect inhomogeneous sample compositions.

$\mathrm{CO}_{2}$ sample splits intended for ${ }^{14} \mathrm{C}$ analysis were reduced to graphite by reaction with hydrogen gas at $570^{\circ} \mathrm{C}$ in the presence of a cobalt metal catalyst and analyzed by accelerator mass spectrometry at Lawrence Livermore National Laboratory (Vogel et al., 1987). Results are reported as percent modern carbon (pmc), which represents the ${ }^{14} \mathrm{C} /{ }^{12} \mathrm{C}$ ratio of the sample normalized to the ratio of 1950 atmospheric $\mathrm{CO}_{2}$ (Stuiver \& Polach, 1977). Radiocarbon ages were calculated using a half-life of 5568 years (Libby, 1955). 


\section{Results}

\section{Calcite Textures}

Appendix A of this report provides brief descriptions of the calcite veins/fracture coatings and their host rock lithologies. For a more detailed description and discussion of calcite textures, coexisting vein minerals, and host rock lithologies, the reader is referred to a companion report (IT Corporation, 1998).

\section{Stable Isotope Results - Interpretation of Saturated vs. Unsaturated Conditions}

Stable isotope results are reported in Table 1. Calcite $\delta^{13} \mathrm{C}$ values range from -5.8 to $+8.0 \%$, and $\delta^{18} \mathrm{O}$ values range from -3.9 to $+22.0 \%$. On a plot of $\delta^{13} \mathrm{C}$ versus $\delta^{18} \mathrm{O}$, the data are separated into three groups on the basis of isotopic composition (Figure 2), reflecting the different environmental conditions under which the calcite formed. These groups include (1) unsaturated zone calcites with $\delta^{13} \mathrm{C}$ values between approximately -6 and $-3 \%$; (2) unsaturated zone calcites with $\delta^{13} \mathrm{C}$ values greater than $+5 \%$; and (3) saturated zone calcites with $\delta^{13} \mathrm{C}$ values between -3 and $+4 \%$.

The transition from unsaturated to saturated conditions at the time of calcite deposition is inferred on the basis of isotopic composition. Modern water table depths on Pahute Mesa are typically between 600 and 700 meters below the surface (Blankennagel and Weir, 1973), but are notably shallower in UE-18t (280 m), PM-2 (260 m) and PM-3 (444 m). Only four samples from this study lie above the current water table: PM-2 (98 m), U-19ar $(53 \mathrm{~m}$ and $475 \mathrm{~m})$, and $U$-20as $(91 \mathrm{~m})$. However, calcite $\delta^{18} \mathrm{O}$ values suggest that a total of eight samples probably formed in the unsaturated zone. The key indication is a discontinuity in the calcite $\delta^{18} \mathrm{O}$ values at a depth of $\sim 600 \mathrm{~m}$.

All Pahute Mesa calcites from below $600 \mathrm{~m}$ depth have $\delta^{18} \mathrm{O}$ values less than $+6 \%$, whereas shallower samples have $\delta^{18} \mathrm{O}$ values greater than $+11 \%$. These variations are consistent with data from Yucca Mountain, Nevada (Figure 3) where saturated zone calcites have $\delta^{18} \mathrm{O}$ values less than $+10 \%$ (Szabo \& Kyser, 1990; Whelan \& Stuckless, 1992; Paces et al., 1996). The similarity in isotopic variations at Pahute Mesa and Yucca Mountain suggests similar conditions for calcite formation at both locations. Saturated zone calcites from Pahute Mesa tend to be lower in $\delta^{18} \mathrm{O}$ than those from Yucca Mountain (Figure 3), reflecting greater sampling depths, and possibly higher paleogeothermal gradients. 


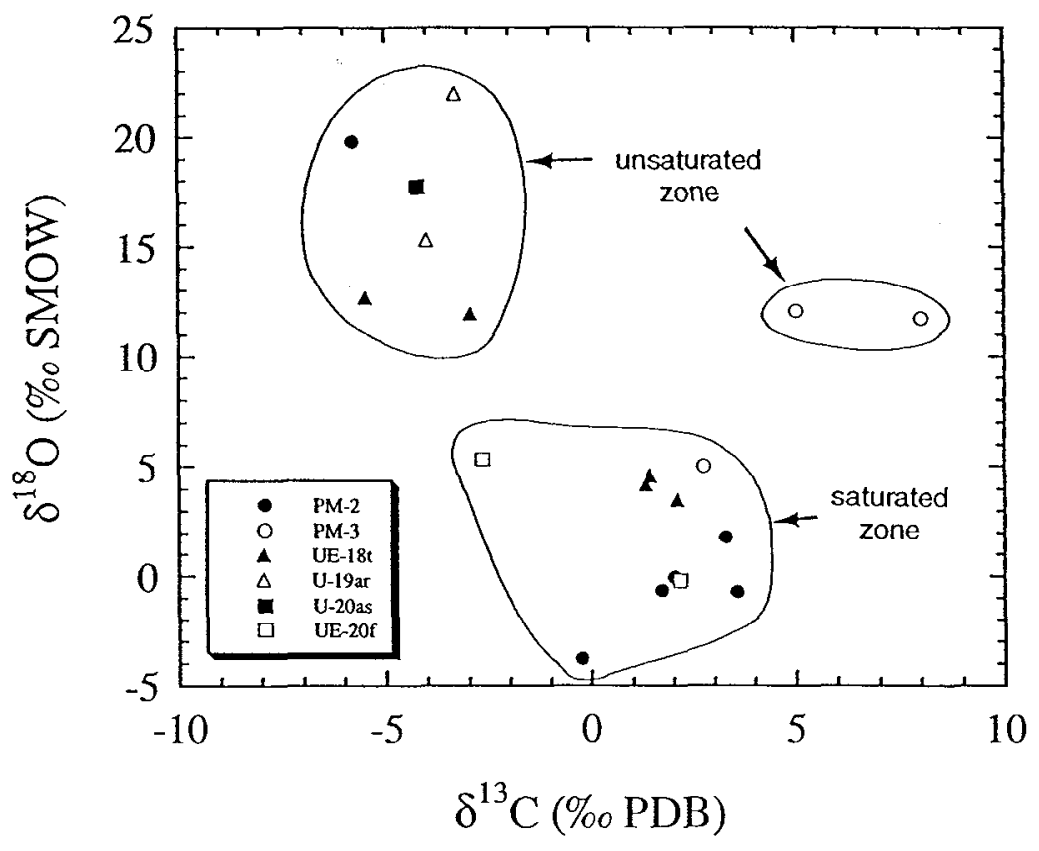

Figure 2. Plot of $\delta^{18} \mathrm{O}$ versus $\delta^{13} \mathrm{C}$ values for Pahute Mesa calcite samples. The data are grouped according to differences in isotopic values that reflect different environmental conditions of formation.

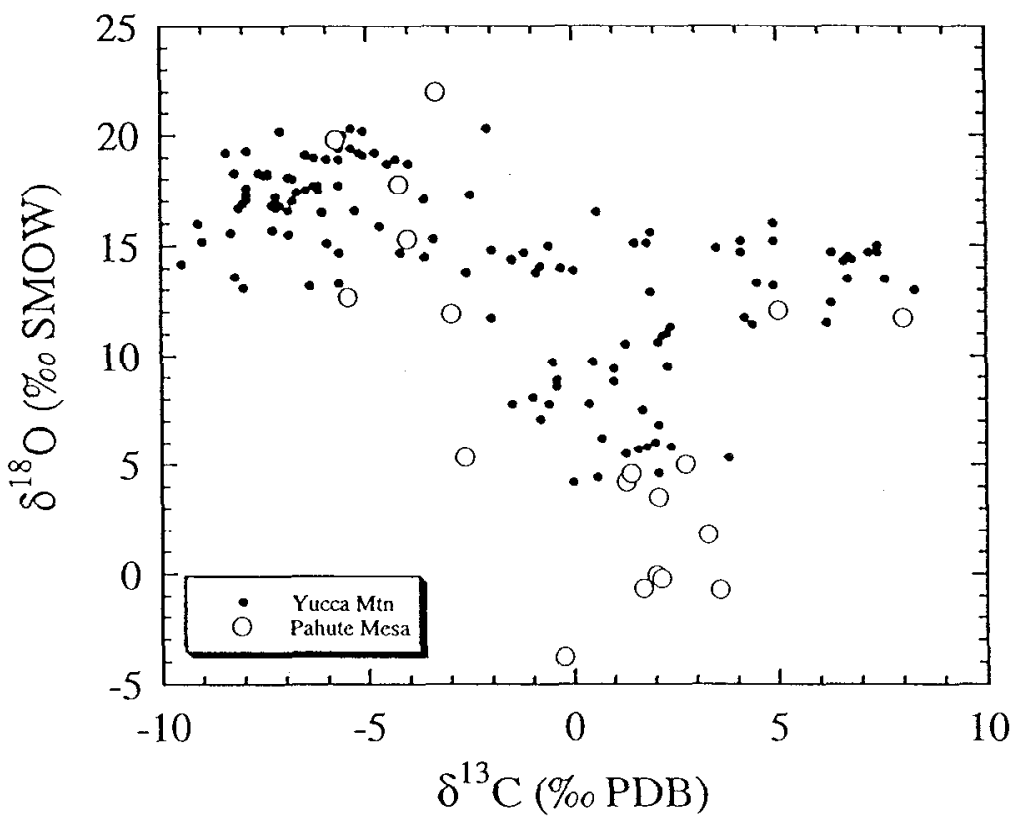

Figure 3. Plot of $\delta^{18} \mathrm{O}$ versus $\delta^{13} \mathrm{C}$ values for calcite samples from Pahute Mesa and Yucca Mountain. The similarity in isotopic variations between the two data sets suggests similar depositional conditions at both locations. Yucca Mountain data was compiled from published results in Szabo \& Kyser (1990), Whelan \& Stuckless (1992) and Paces et al. (1996). 


\section{Unsaturated zone calcite}

Most unsaturated zone calcites from Pahute Mesa have $\delta^{13} \mathrm{C}$ values between -6 and $-3 \%$. This range in values is consistent with a pedogenic (soil zone) carbon source. Pedogenic carbonate forms in arid environments during mineral weathering processes involving soil $\mathrm{CO}_{2}$ (Salomons \& Mook, 1986). The carbon isotopic composition of the soil carbonate is determined by the soil $\mathrm{CO}_{2}$ gas composition, and reflects the type of vegetation in the area (Cerling, 1984). Quade et al. (1989) showed that pedogenic carbonate $\delta^{13} \mathrm{C}$ values decrease systematically with increasing elevation in southern Nevada, ranging from about -3 to $-7 \%$ at elevations between 1500 to $2000 \mathrm{~m}$. This is the approximate range in surface clevations for wells represented in this study, and is consistent with the obscrved range in $\delta^{13} \mathrm{C}$ values for many unsaturated zone calcites from this study.

Calcite in the deep unsaturated zone probably accumulates slowly over time as dissolved inorganic carbon in percolating waters carries soil carbonate down along fractures in the rock (Whelan \& Stuckless, 1992). This implies surface recharge periodically infiltrates to great depths in the unsaturated zone. The $\delta^{18} \mathrm{O}$ values of unsaturated zone calcites from Pahute Mesa range from +11.7 to $+22.0 \%$, indicating that calcite formed at low to moderate temperatures by precipitation from local meteoric waters (see discussion below).

Two calcite samples from the unsaturated zone have relatively enriched $\delta^{13} \mathrm{C}$ values of +5.0 and +8.0 (Figure 2). Both samples are from approximately the same depth interval in well PM-3, and occur in fractured basalt as powdery fracture coatings and vesicle fillings. Similar ${ }^{13} \mathrm{C}$-enriched calcites were also observed in the unsaturated zone at Yucca Mountain (Paces et al., 1996). The isotopically heavy $\delta^{13} \mathrm{C}$ values suggest that calcite precipitation occurred during methane-producing chemical reactions, such as the decarboxylation of short-chain aliphatic acids (e.g. $\mathrm{CH}_{3} \mathrm{COO}^{-}+\mathrm{H}_{2} \mathrm{O} \rightarrow \mathrm{HCO}_{3}^{-}+\mathrm{CH}_{4}$, cf. Carothers and Kharaka, 1980). Isotopic fractionation of ${ }^{12} \mathrm{C}$ into $\mathrm{CH}_{4}$ during this process causes cocxisting bicarbonate ions to become highly enriched in ${ }^{13} \mathrm{C}$ (Bottinga, 1969). Unsaturated zone calcites from the Bandelier tuff in New Mexico were recently found to contain methane-rich fluid inclusions, suggesting that isotopically-enriched calcite may form during the microbial decomposition of organic matter (Newman et al., 1997). 


\section{Saturated zone calcite}

Calcite samples from the saturated zone at Pahute Mesa have $\delta^{13} \mathrm{C}$ values between -3 and $+4 \%$, although most of the data clusters around +1 to $+4 \%$ (Figure 2 ). These values are similar to those of Paleozoic carbonate rocks that underlie the volcanic section (cf. Thomas et al., 1996, Table 17) and suggest the saturated zone calcite precipitated from water containing dissolved inorganic carbon originating from the Paleozoic carbonate aquifer (Whelan \& Stuckless, 1992). The same process was documented for calcite deposited during former high stands of the water table in Yucca Flat (Smith et al., 1998). Groundwater from the Paleozoic carbonate aquifer has $\delta^{13} \mathrm{C}$ values ranging from -0.7 to $-6.1 \%$, with an average value around $-3.8 \%$ o $(\mathrm{n}=30)$ (Winograd \& Pearson, 1976; Benson \& McKinley, 1985; Rose et al., 1997, 1998a). Calcite is enriched in ${ }^{13} \mathrm{C}$ by $\sim 1 \%$ o relative to dissolved bicarbonate at $25^{\circ} \mathrm{C}$ (Rubinson \& Clayton, 1969), and shows increasing ${ }^{13} \mathrm{C}$ enrichment at higher temperatures (Mook, 1986) or during $\mathrm{CO}_{2}$ exsolution. Precipitation temperatures of 75 to $150^{\circ} \mathrm{C}$ will account for most saturated zone calcite $\delta^{13} \mathrm{C}$ values, assuming a carbonate aquifer carbon source. This range in temperatures is in general agreement with temperatures estimated from calcite $\delta^{18} \mathrm{O}$ data, and suggests an elevated geothermal gradient during calcite deposition (see below).

\section{Paleo-temperature estimates from calcite $\delta^{18} \mathrm{O}$ results}

When calcite is formed, oxygen isotopes are partitioned (fractionated) between the calcite and coexisting water according to temperature. The oxygen isotope composition of a calcite therefore provides a record of the temperature at which the calcite formed. A precise determination of this temperature requires knowledge of $\delta^{18} \mathrm{O}$ value of the water. However, if the water $\delta^{18} \mathrm{O}$ value can be reasonably estimated, the $\delta^{18} \mathrm{O}$ value of the calcite provides a useful paleo-temperature indicator.

The $\delta^{18} \mathrm{O}$ values of Pahute Mesa calcites generally decrease with increasing depth, in response to increasing temperature. In the saturated zone, calcite $\delta^{18} \mathrm{O}$ values range from +5.3 to $-3.9 \%$ and plot along a steeply dipping trend (Figure 4), although the pattern is not consistent from well to well. For example, calcite samples from well UE-20f (open squares) appear to lie along a lower thermal gradient compared to most other saturated zone samples. 


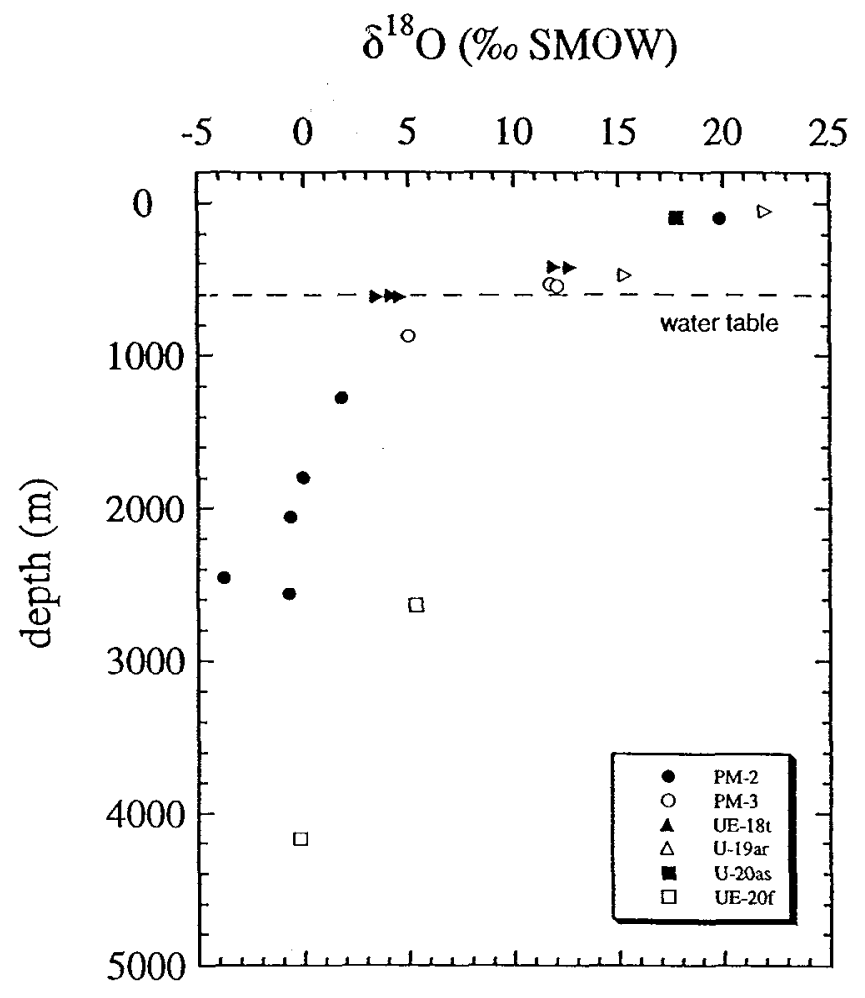

Figure 4. Plot of $\delta^{18} \mathrm{O}$ versus sample depth for Pahute Mesa calcite samples. The $\delta^{18} \mathrm{O}$ values generally decrease with increasing depth, in response to increasing temperature. The inferred transition from unsaturated to saturated conditions during calcite formation is marked by the dashed line (water table) at $600 \mathrm{~m}$ depth, and is based on similarities to Yucca Mountain calcite data.

The temperature dependent calcite-water fractionation equation developed by O'Neil and others (1969) was uscd to estimate calcite deposition temperatures. The results are reported in Table 1. As previously noted, the exact $\delta^{18} \mathrm{O}$ value of the water from which the calcite formed is unknown, but it can be estimated. Modern groundwater from the volcanic aquifers on Pahute Mesa has a $\delta^{18} \mathrm{O}$ value near -15\%o (Rose et al., 1997). It is assumed that saturated zone calcites formed from water of this composition, although this value may have varied through time. Calcite in the unsaturated zone formed from meteoric waters percolating down from the surface. Modern meteoric water from Pahute Mesa has an average $\delta^{18} \mathrm{O}$ value around $-12.5 \%$ (Benson \& Klieforth, 1989; Ingraham et al., 1991). Evaporation during groundwater infiltration will cause isotopic enrichment, yielding somewhat higher $\delta^{18} \mathrm{O}$ values. Due to uncertainties in assumed $\delta^{18} \mathrm{O}_{\text {water }}$ values, we have calculated calcite-water equilibrium temperatures using three different $\delta^{18} \mathrm{O}_{\text {water }}$ compositions: $-15,-12.5$ and $-10 \%$ (Table 1). 
In the unsaturated zone, paleo-temperature estimates range from 0 to $47^{\circ} \mathrm{C}$ for $\delta^{18} \mathrm{O}_{\text {water }}=$ $-12.5 \%$, and from 9 to $63^{\circ} \mathrm{C}$ for $\delta^{18} \mathrm{O}_{\text {water }}=-10 \%$. Some near-surface samples (from depths $<100 \mathrm{~m}$ ) yield unrealistically low temperature estimates, indicating that the calcite formed from highly evaporated water $\left(\delta^{18} \mathrm{O}>-10 \%\right)$. Excluding these samples and assuming $\delta^{18} \mathrm{O}_{\text {water }}=-12.5 \%$, the calcite-water equilibrium temperatures suggest a paleogeothermal gradient between 55 and $70^{\circ} \mathrm{C} / \mathrm{km}$ for the unsaturated zone. This calculation assumes a mean annual surface temperature of $15^{\circ} \mathrm{C}$ (Sass et al., 1980). The estimated paleo-geothermal gradient for Pahute Mesa is notably higher than the modern geothermal gradient at Yucca Mountain, where borehole gradients range from 36 to $45^{\circ} \mathrm{C} / \mathrm{km}$ (Sass et al., 1980). Szabo \& Kyser (1990) showed that unsaturated zone calcite from Yucca Mountain fit a model geothermal gradient of $34^{\circ} \mathrm{C} / \mathrm{km}$. These results imply that many of the unsaturated zone calcites from Pahute Mesa formed at a time when geothermal gradients were higher than they are today.

Saturated zone calcite paleo-temperatures range from 72 to $170^{\circ} \mathrm{C}$, assuming $\delta^{18} \mathrm{O}_{\text {water }}=$ $-15 \%$, with the highest temperatures occurring in samples from well PM-2. Figure 5 shows variations in calcite $\delta^{18} \mathrm{O}$ values versus depth over a range of geothermal gradients. The curves in Figure 5 indicate the $\delta^{18} \mathrm{O}$ values of calcite in equilibrium with $-15 \%$ o groundwater along geothermal gradients of $22,34,45,60$ and $75^{\circ} \mathrm{C} / \mathrm{km}$, assuming a surface temperature of $15^{\circ} \mathrm{C}$. Samples from wells PM-2 and PM-3 are consistent with a gradient between approximately 45 and $70^{\circ} \mathrm{C} / \mathrm{km}$, similar to that of the unsaturated zone samples. Samples from UE-20f fall along a lower geothermal gradient ranging from 22 to $28^{\circ} \mathrm{C} / \mathrm{km}$, whereas UE- $18 \mathrm{t}$ samples plot above the $75^{\circ} \mathrm{C} / \mathrm{km}$ geotherm and suggest a gradient as high as $135^{\circ} \mathrm{C} / \mathrm{km}$. The latter samples lie very close to the inferred paleowater table, and indicate temperatures well above the modern geothermal gradient once occurred at relatively shallow levels.

Electron microprobe studies revealed cation-substitution effects in some calcite samples, or the presence of other carbonate minerals coexisting with calcite (e.g. ankerite, dolomite, siderite) (IT Corporation, 1998). Fractionation factors reported by Rosenbaum \& Sheppard (1986) suggest that cation-substitution should not significantly influence the temperature estimates reported above. Moreover, samples prepared for isotopic analysis during this study were reacted with $\mathrm{H}_{3} \mathrm{PO}_{4}$ at $25^{\circ} \mathrm{C}$ for time periods $<24$ hours. The reaction kinetics for pure carbonate minerals other than calcite are sufficiently slow at $25^{\circ} \mathrm{C}$ (Al-Aasm et al, 1990) that we can assume most of the $\mathrm{CO}_{2}$ produced during reaction was from calcite. 


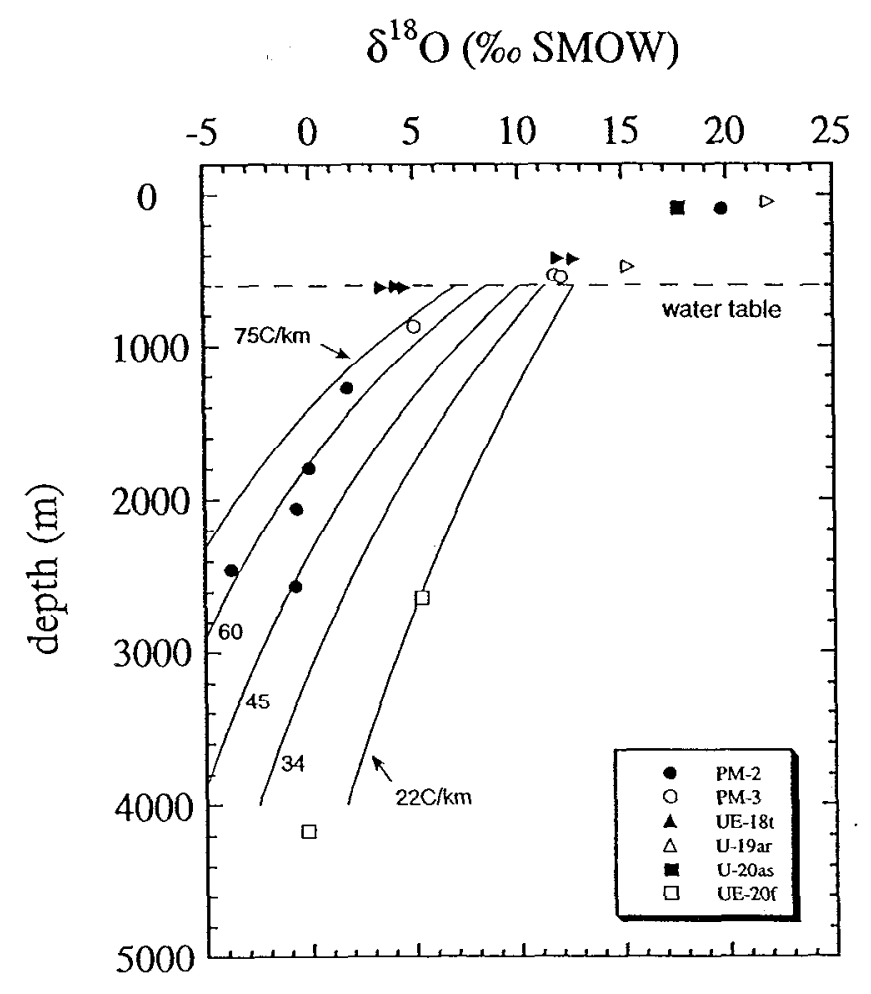

Figure 5. Same plot as shown in Figure 4, but with curves indicating the $\delta^{18} \mathrm{O}$ values of saturated zone calcites in equilibrium with $-15 \%$ groundwater along geothermal gradients of $22,34,45,60$ and $75^{\circ} \mathrm{C} / \mathrm{km}$. Mean annual surface temperature is assumed to be $15^{\circ} \mathrm{C}$. A number of the saturated zone samples fall along elevated geotherms of $>45^{\circ} \mathrm{C} / \mathrm{km}$, indicating hydrothermal deposition. Temperatures estimated from the calcite-water isotopic fractionation factor range as high as $170^{\circ} \mathrm{C}$. Samples from UE-20f fall along a lower geothermal gradient ranging from 22 to $28^{\circ} \mathrm{C} / \mathrm{km}$. These samples may have been deposited from ambient groundwater, although wall rock alteration implies hydrothermal deposition from an ${ }^{18} \mathrm{O}$-shifted groundwater is more likely for the $4168 \mathrm{~m}$ sample.

\section{Radiocarbon}

A total of 11 radiocarbon measurements were performed on 10 different samples to determine whether any of the Pahute Mesa calcites exhibit measurable ${ }^{14} \mathrm{C}$ ages $(<42,500$ years). Much of the calcite in veins from the saturated zone is relatively homogeneous in structure. These textures imply a single episode of calcite deposition. Two saturated zone samples and one unsaturated zone sample showed clear evidence for depositional layering, and efforts were taken to carefully separate and analyze material from the upper surface of each vein. Two of these samples were from well PM-2 (98 m and $1796 \mathrm{~m}$ ) and 
one was from well UE-18t (616 in). Radiocarbon analyses of the outer portion of each of these veins yielded ${ }^{14} \mathrm{C}$ activities below the detection limit. In fact, only one sample showed a radiocarbon value above the analytical detection limit of $\sim 0.5$ pmc. This sample is inferred to have formed in the unsaturated zone (well PM-3, $533 \mathrm{~m}$ ) and has a ${ }^{14} \mathrm{C}$ activity of $0.83 \mathrm{pmc}$, yielding a 38,500 year age. This sample also showed an unusually enriched $\delta^{13} \mathrm{C}$ value of $+8 \%$, implying calcite deposition during methanogenesis.

\section{Discussion and Recommendations}

The isotopic data presented in this report provides a useful reference point for evaluating calcite dissolution and isotopic exchange processes in the western Pahute Mesa-Oasis Valley flow system. From this standpoint, the most significant results are the $\delta^{13} \mathrm{C}$ and ${ }^{14} \mathrm{C}$ compositions of the saturated zone calcites. The calcite samples were classified according to their host hydrostratigraphic units, thereby providing a means of correlating calcite isotopic values with specific aquifers (IT Corporation, 1998). These units include: (1) the Timber Mountain aquifer; (2) the upper Paintbrush confining unit; (3) the Calico Hills confining unit; (4) the Belted Range aquifer; and (5) the pre-Belted Range composite unit.

Figure 6 is a plot of $\delta^{13} \mathrm{C}$ versus sample depth wherein data points are identified according to hydrostratigraphic unit. At depths $<1000 \mathrm{~m}$, the Timber Mountain tuff is the principal aquifer. This unit is important with regard to radionuclide migration since many of the underground nuclear tests conducted on Pahute Mesa had working points at this depth (Laczniak et al., 1996; Table 5). The variability in calcite $\delta^{13} \mathrm{C}$ compositions within the Timber Mountain aquifer reflects calcite deposition under both unsaturated and saturated conditions. At depths greater than $1000 \mathrm{~m}$, most of the calcite samples are from the pre-Belted Range composite aquifer (Figure 6). Most of these samples are of hydrothermal origin, with a carbon source derived from the lower carbonate aquifer. A single sample from the Belted Range aquifer (UE-20f, $2641 \mathrm{~m}$ ) has a $\delta^{18} \mathrm{O}$ value that suggests deposition from deep circulation of modern groundwater. The host rock for this calcite is a highly fractured rhyolite containing abundant oxide minerals. These characteristics are consistent with a zone that is transmissive to groundwater flow. 


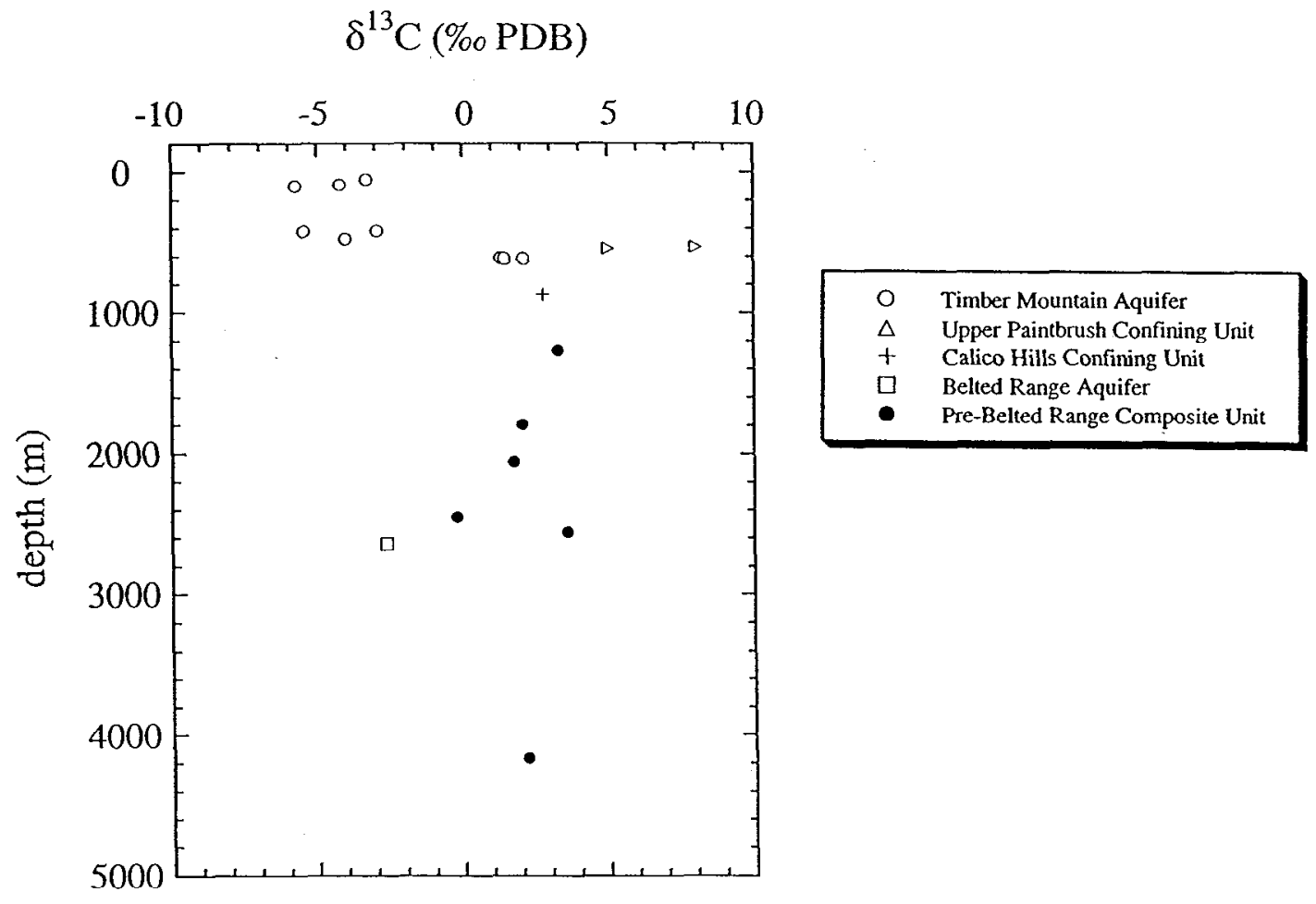

Figure 6. Plot of $\delta^{13} \mathrm{C}$ versus sample depth for Pahute Mesa calcite samples. Data points are labeled with respect to hydrostratigraphic unit to show the range in $\delta^{13} \mathrm{C}$ compositions for different aquifer units.

Groundwater samples from wells on Pahute Mesa are highly variable in their $\delta^{13} \mathrm{C}$ values, ranging from -11.1 to $-1.4 \%$, with ${ }^{14} \mathrm{C}$ values between 25 and 9 pmc (Rose et al., 1997, $1998 \mathrm{~b}$ ). However, groundwater $\delta^{13} \mathrm{C}$ values generally increase (hecome less negative) as ${ }^{14} \mathrm{C}$ values decrease -- a pattern that is consistent with calcite dissolution reactions. Groundwater samples from wells that lie between Oasis Valley and Pahute Mesa also show evidence of calcite dissolution or isotopic exchange reactions (e.g. ER-OV-1: $\delta^{13} \mathrm{C}$ $=-1.4 \%,{ }^{14} \mathrm{C}=5 \mathrm{pmc}$; data from Rose et al., 1998b).

Water chemistry data generated by the Desert Research Institute during FY98 indicate that most of the Oasis Valley groundwaters are saturated with respect to calcite (R.L. Hershey, personal communication, 1998). This saturation state may reflect calcite dissolution processes in the Pahute Mesa aquifers. However, Oasis Valley basin groundwaters are notably elevated in ${ }^{3} \mathrm{He}$, which implies a mantle-derived gas flux enters 
the groundwater system along deep crustal fault zones (Rose et al., 1998b). Since mantle helium is generally accompanied by $\mathrm{CO}_{2}$ gas (e.g. Hilton, 1996; Sorey et al., 1998) this process may cause groundwater $\mathrm{pH}$ values to decrease, which will promote calcite dissolution. It is therefore of interest to know something about secondary calcite that occurs down gradient from Pahute Mesa. Sidewall core and cuttings samples from the ER-OV wells and the new ER-EC wells should be examined for the presence of secondary minerals, particularly calcite. If calcite is found, isotopic measurements on those samples may provide new information regarding the evolution of the groundwater chemistry in the region between Pahute Mesa and the Oasis Valley discharge zone.

Additional information on the origin and age of secondary calcite samples could be obtained from ${ }^{87} \mathrm{Sr} /{ }^{86} \mathrm{Sr}$ measurements and uranium-series dating. The former method is useful in discriminating between different carbonate sources, while the latter is useful in dating carbonate material with ages up to $\sim 600,000$ years $\left({ }^{230} \mathrm{Th} /{ }^{238} \mathrm{U}\right.$ disequilibrium method). The uranium-series dating technique may be particularly useful in understanding the sequential depositional history of multi-layer calcite veins.

\section{References}

Al-Aasm, I.S., Taylor, B.E., and South, B. (1990), Stable isotope analysis of multiple carbonate samples using selective acid extraction. Chem. Geol., v. 80, pp. 119-125.

Benson, L.V., and McKinley, P.W. (1985), Chemical composition of ground water in the Yucca Mountain area, Nevada, 1971-84. U.S. Geol. Survey Open-File Report 85-484, 10 p.

Blankennagel, R.K., and Weir, J.E., Jr. (1973), Geohydrology of the eastern part of Pahute Mesa, Nevada Test Site, Nye County, Nevada. U.S. Geol. Survey Prof. Paper 712-B, 35 p.

Bottinga, Y. (1969), Calculated fractionation factors for carbon and hydrogen isotope exchange in the system calcite-carbon dioxide-graphite-methane-hydrogen-water vapor. Geochim. Cosmochim. Acta, v. 33 , pp. $49-64$.

Carothers, W.W. and Kharaka, Y.K. (1980), Stable carbon isotopes of $\mathrm{HCO}_{3}{ }^{-}$in oil-field waters implications for the origin of $\mathrm{CO}_{2}$. Geochim. Cosmochim. Acta, v. 44, pp. 323-332.

Cerling, T.E. (1984), The stable isotopic composition of modern soil carbonate and its relationship to climate. Earth Planet. Sci. Lett., v. 71, pp. 229-240.

Coplen, T.B., Kendall, C., and Hopple, J. (1983), Comparison of stable isotope reference samples. Nature, v. 302, pp. $236-238$. 
Department of Energy (1997), Regional groundwater flow and tritium transport monitoring and risk assessment of theunderground test area, Nevada Test Site, Nevada. U.S. Department of Energy, Nevada Operations Office, Environmental Restoration Division, DOE/NV-477, Las Vegas, NV.

Hilton, D.R. (1996), The helium and carbon isotope systematics of a continental geothermal system: results from monitoring studies at Long Valley caldera (California, U.S.A.). Chem. Geol., v. 127, pp. 269-295.

Ingraham, N.L., Lyles, B.F., Jacobson, R.L., and Hess, J.W. (1991), Stable isotopic study of precipitation and spring discharge in southern Nevada. J. Hydrol. v. 125, pp. 243-258.

IT Corporation (1998), Summary of micrographic analysis of fracture coating phases on drill core samples from Pahute Mesa, Nevada Test Site. Report prepared for U.S. Department of Energy, Nevada Operations Office, Las Vegas, NV, DOE/NV/13052, Revision 1, December 1998.

Isotope Sciences Division (1995), Underground Test Area Remedial Investigation/Feasibility Study, Standard Operating Procedures. Lawrence Livermore National I aboratory, unpublished report.

Laczniak, R.I., Cole, I.C., Sawyer, D.A., and Trudeau, D.A. (1996), Summary of hydrogeologic controls on groundwater flow at the Nevada Test Site, Nye County, Nevada. U.S. Geol. Survey WaterResources Investigations Report 96-4109, 59 p.

Libby, W.F. (1955), Radiocarbon dating, $2^{\text {nd }}$ edition. University of Chicago Press, Chicago, 175 p.

McCrea, J.M. (1950), On the isotopic chemistry of carbonates and a paleotemperature scale. Jour. Chem. Phys., v. 18, pp. 849-857.

Mook, W.G. (1986), ${ }^{13} \mathrm{C}$ in atmospheric $\mathrm{CO}_{2}$. Netherlands Journal of Sea Research, v. 20, pp. 211-223.

Newman, B.D., Campbell, A.R., Norman, D.I., and Ringelberg, D.B. (1997), A model for microbially induced precipitation of vadose-zone calcites in fractures at Los Alamos, New Mexico, USA. Geochim. Cosmochim. Acta, v. 61, pp. 1783-1792.

O'Neil, J.R., Clayton, R.N., and Mayeda, T.K. (1969), Oxygen isotope fractionation in divalent metal carbonates. Jour. Chem. Physics, v. 51, pp. 5547-5558.

Paces, J.B., Neymark, L.A., Marshall, B.D., Whelan, J.F., and Peterman, Z.E. (1996), Ages and origins of subsurface secondary minerals in the exploratory studies facility (ESF). U.S. Geol. Survey, Yucca Mountain Project Branch, 1996 Milestone Report 3GQH450M, 55 p.

Quade, J., Cerling, T.E., and Bowman, J.R. (1989), Systematic variations in the carbon and oxygen isotopic composition of pedogenic carbonate along elevation transects in the southern Great Basin, United States. Geol. Soc. Am. Bull., v. 101, pp. 464-475.

Reed, W.P. (1992), Report of investigation, reference materials 8543-8546. National Institute of Standards and Technology Report, June 22, 1992, 3 p.

Rose, 'I.P., Kenneally, J.M., Smith, D.K., Davisson, M.L., Hudson, G.B., and Rego, J.H. (1997), Chemical and isotopic data for groundwater in southern Nevada. Lawrence Livermore National Laboratory UCRL-ID-128000, $35 \mathrm{p}$. 
Rose, T.P., Davisson, M.L., Smith, D.K., and Kenneally, J.M. (1998a), Isotope hydrology investigation of regional groundwater flow in central Nevada. In: D.K. Smith, ed., Iydrologic Resources Management Program and Underground Test Area Operable Unit FY 1997 Progress Report, Lawrence Livermore National Laboratory, UCRL-ID-130792, pp. 53-75.

Rose, T.P., Kenneally, J.M., IIudson, G.B., Eaton, G.F., and Smith, D.K. (1998b), Tritium, hclium and carbon isotopic data for groundwater from Oasis Valley and Pahute Mesa: FY98 analytical results. Report submitted to UGTA Operablc Unit, U.S. Department of Energy, Nevada Operations Office, Las Vegas, NV. September 1998.

Rosenbaum, J. and Sheppard, S.M.F. (1986), An isotopic study of siderites, dolomites and ankerites at high temperatures. Geochim. Cosmochim. Acta, v. 50, pp. 1147-1150.

Rubinson, M., and Clayton, R.N. (1969), Carbon 13 fractionation between aragonite and calcite. Geochim. Cosmochim. Acta, v. 33, pp. 997-1002.

Salomons, W., and Mook, W.G. (1986), Isotope geochemistry of carbonates in the weathering zone. In: P. Fritz and J.Ch. Fontes, eds., Handbook of Environmental Isotope Geochemistry, vol. 2, The Terrestrial Environment, B. Elsevier, Amsterdam, pp. 239-269.

Sass, J.H., Lachenbruch, A.H., and Mase, C.W. (1980), Analysis of thermal data from drill holes UE25a-3 and UE-25a-1, Calico Hills and Yucca Mountain, Nevada Test Site. U.S. Geol. Survey Open-File Report 80-826, 25 p.

Smith, D.K., Rose, T.P., Davisson, M.L., Hudson, G.B., Niemeyer, S., and Moeller, A.E. (1998), Volatile and fluid transport in deep, arid soils. Lawrence Livermore National Laboratory, UCRL-ID-129653, $10 \mathrm{p}$.

Sorey, M.L., Evans, W.C., Kennedy, B.M., Farrar, C.D., Hainsworth, L.J., and Hausback, B. (1998), Carbon dioxide and helium emissions from a reservoir of magmatic gas beneath Mammoth Mountain, California. Jour. Geophys. Res., v. 103, pp. 15,303-15,323.

Stuiver, M., and Polach, H. (1977), Reporting of ${ }^{14} \mathrm{C}$ data. Radiocarbon, v. 19, pp. 355-363.

Szabo, B.J., and Kyser, T.K. (1990), Ages and stable isotope compositions of secondary calcite and opal in drill cores from Tertiary volcanic rocks of the Yucca Mountain area, Nevada. Geol. Soc. Am. Bull., v. 102, pp. 1714-1719.

Thomas, J.M., Welch, A.H., and Dettinger, M.D. (1996), Geochemistry and isotope hydrology of representative aquifers in the Great Basin region of Nevada, Utah, and adjacent states. U.S. Geol. Survey Prof. Paper 1409-C, 100 p.

Vogel, J.S., Southon, J.R., and Nelson, D.E. (1987), Catalyst and binder effects in the use of filamentous Graphite for AMS. Nuclear Instruments and Methods in Physics Research, B29, pp. 50-56.

Whelan, J.F., and Stuckless, J.S. (1992), Paleohydrologic implications of the stable isotopic composition of secondary calcite within the Tertiary volcanic rocks of Yucca Mountain, Nevada. In: Proceedings of the Third International Conference on High Level Radioactive Waste Management, April 12-16, 1992, Las Vegas, NV, pp. 1572-1581.

Winograd, I.J., and Pearson, F.J., Jr. (1976), Major carbon-14 anomaly in a regional carbonate aquifer: possible evidence for megascale channeling, south central Great Basin. Water Resour. Res., v. 12, pp. $1125-1143$. 
Table 1. Stable isotope and radiocarbon data for Pahute Mesa calcite samples

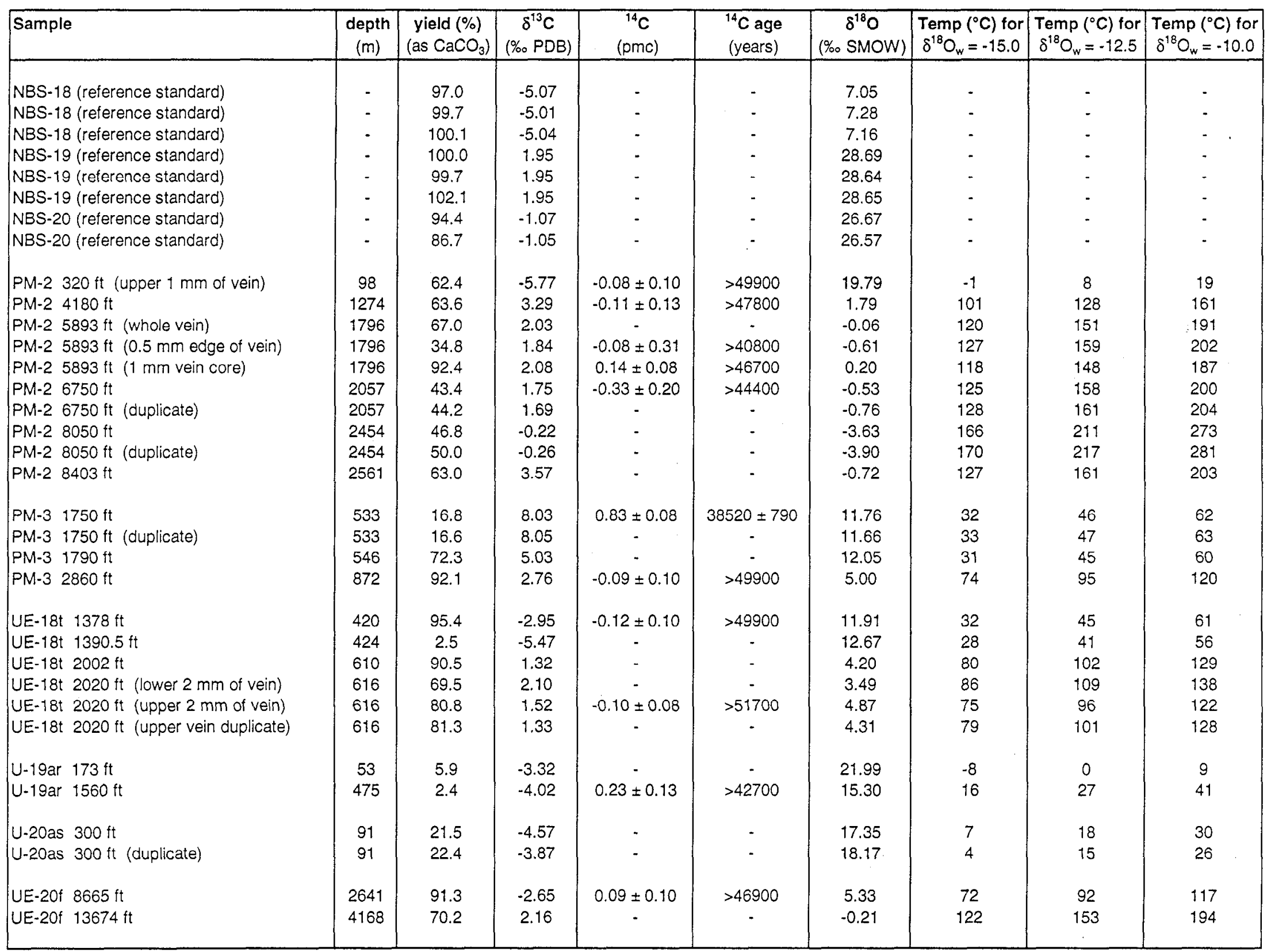

Duplicate analyses represent independent measurements of sample splits. 


\section{Appendix A. Descriptions of samples selected for isotopic analysis of calcite}

Borehole PM-2

Location: N 944,581 E 528,656

Surface Elevation: $1703 \mathrm{~m}(5586 \mathrm{ft})$

Total Depth: 2677 m (8782 ft)

98 m (320 ft) Spearhead Member, Thirsty Canyon Tuff. Lt. to dk. gray, densely welded vitric ash-flow tuff. Tuff is cut by a vein of calcite + chalcedony up to $7 \mathrm{~mm}$ in thickness, with freegrowing blocky calcite spar crystals on the upper surface. In cross-section, the calcite/chalcedony intergrowth pattern is complex and irregular (lacey), and suggests the two phases may have coprecipitated. Calcite is most abundant at the base and top of the vein; chalcedony is dominant in the central $4 \mathrm{~mm}$ of the vein. Chalcedony is strongly fluorescent green in SW ultraviolet light.

$1274 \mathrm{~m}$ (4180 ft) Dacite lavas of the Belted Range. Lt. pinkish-gray, dense, porphyritic, with altered feldspar phenocrysts up to $4 \mathrm{~mm}$. Calcite fracture fillings are 1-2 $\mathrm{mm}$ in thickness, consisting of densely intergrown, coarse spar crystals.

$1796 \mathbf{m}(5893 \mathrm{ft})$ Porphyritic rhyodacite lava flow of the Belted Range. Reddish-gray, with plagioclase phenocrysts to $5 \mathrm{~mm}$ comprising $25 \%$ of rock. Rock is hard, silicified and sericitized; highly fractured in this interval. Fractures are filled with calcite veins up to $4 \mathrm{~mm}$ in thickness (+ chlorite + hematite). Calcite veinlets easily separated from rock, exhibiting cross-fiber texture.

$2057 \mathrm{~m}(6750 \mathrm{ft})$ Dacite lavas of the Belted Range. Lt. green, altered dacite, containing thin $(\sim 0.1-0.3 \mathrm{~mm})$ brittle crusts/fracture coatings of microcrystalline calcite.

$2454 \mathrm{~m}(8050 \mathrm{ft})$ Dacite lavas of the Belted Range. Dk. grayish-olive to greenish-black dacite, silicified and pyritized. Plagioclase phenocrysts altered to epidote. Rock is cut by thick veins of calcite and diopside (?). Sample selected for analysis consists of a single vein of calcite, $\sim 1 \mathrm{~cm}$ thick, with coarse (to $3 \mathrm{~mm}$ ) interlocking calcite crystals.

$2561 \mathrm{~m}$ (8403 ft) Brecciated granodiorite. Pinkish-gray, sericitized granitic rock with white to gray calcite veinlets to $\sim 1 \mathrm{~mm}$ thick, associated with minor chlorite + pyrite. Calcite consists of granular, interlocking crystals $<1 \mathrm{~mm}$ in size.

\section{Borehole PM-3}

Location: N 906,022 E 530,998

Surface Elevation: $1775 \mathrm{~m}(5823 \mathrm{ft})$

Total Depth: $920 \mathrm{~m}$ (3019 ft)

$533 \mathrm{~m}$ (1750 ft) Basalt, brick-red, zeolitized and argillized, weakly calcareous. Abundant altered plagioclase; vugs are filled with montmorillonite and (rare) analcime. Sample consists of a 1.5 inch percussion gun sidewall core. Calcite occurs as white, microcrystalline coatings and encrustations on altered plagioclase, and is disseminated through the groundmass. 
$546 \mathbf{~ m ~ ( 1 7 9 0 ~ f t ) ~ B a s a l t ; ~ f i n e - g r a i n e d ~ c u t t i n g s . ~ C a l c i t e ~ i s ~ p r e s e n t ~ a s ~ g r a n u l a r ~ f r a c t u r e ~ c o a t i n g s ~ a n d ~}$ vesicle fillings, and less commonly as blocky cleavage fragments of vein material.

$872 \mathrm{~m}(2860 \mathrm{ft})$ Basalt, dark red to black cuttings with small plagioclase phenocrysts. Calcite is present as thin veinlets and fracture coatings up to $1 \mathrm{~mm}$ thick.

Borehole UE-18t

Location: N 865,793 E 598,394

Surface Elevation: $1585 \mathrm{~m}(5201 \mathrm{ft})$

Total Depth: $792 \mathrm{~m}(2600 \mathrm{ft})$

$420 \mathrm{~m}(\mathbf{1 3 7 8} \mathrm{ft})$ Pumice lapilli tuff of the Ammonia Tanks Member of the Timber Mountain Tuff. Light-gray, hydrothermally altered tuff cut by an open vein with large, platy calcite crystals (individual crystals to $8 \mathrm{~mm}$ ) and coarse crystalline calcite intergrowths. Associated vein minerals include microcrystalline zeolites (analcime), clays and pyrite. It is notable that this vein has abundant open space where water could pass.

$424 \mathrm{~m}$ (1390.5 ft) Pumice lapilli tuff of the Ammonia Tanks Member of the Timber Mountain Tuff. Same lithology as $1378 \mathrm{ft}$. sample. A large fracture is also present in this sample. Calcite occurs as fine-grained, lt. greyish-brown microcrystalline coatings and crusts, admixed with clays on the vein surface. Coarse calcite crystals also occur here, but are less abundant than in the 1378 ft. sample. The calcite sample was taken from the fine-grained material.

$610 \mathrm{~m}(2002 \mathrm{ft})$ Rainier Mesa Member of the Timber Mountain Tuff. Light-gray, moderately welded ash-flow tuff. Calcite occurs as irregular fracture coatings 1-2 mm thick, consisting of coarse, dense intergrown crystals associated with fine-grained hematite.

$616 \mathrm{~m}(2020 \mathrm{ft})$ Rainier Mesa Member of the Timber Mountain Tuff. Same lithology as $2002 \mathrm{ft}$. sample. Rock is cross-cut by a $5 \mathrm{~mm}$ thick calcareous vein with two distinctive parts. The lower $\sim 2 \mathrm{~mm}$ thick segment consists of hard, dense, interlocking calcite crystals up to $1 \mathrm{~mm}$ in size, greyish-white to reddish-purple in color (hematite inclusions). This part of the vein is in contact with the wall rock. The upper $\sim 3 \mathrm{~mm}$ thick segment consists of pod-like masses of intergrown calcite crystals interspersed throughout fine-grained, peach-colored (iron-stained) clay minerals. Individual samples were prepared from each vein segment.

Borehole U-19ar

Location: N 920,569 E 590,500

Surface Elevation: $2044 \mathrm{~m}(6707 \mathrm{ft})$

Total Depth: $671 \mathrm{~m}(2200 \mathrm{ft})$

$53 \mathrm{~m}$ (173 ft) Pahute Mesa Member of the Thirsty Canyon Tuff. Pale orange-gray, highly calcareous reworked tuff with white vitric pumice fragments. Sample consists of 1.5 inch long percussion gun sidewall core. Calcite is finely dispersed throughout the matrix, and is concentrated in pumice fragments $(\sim 5 \%$ of matrix). 
$475 \mathrm{~m}$ (1560 ft) Pool member of the Timber Mountain Tuff. Lt. yellowish-brown, highly calcareous reworked bedded tuff with white vitric pumice fragments. Calcite is disseminated in matrix; pumice fragments are highly calcareous, and comprise $5-10 \%$ of matrix.

Borehole U-20as

Location: N 899,201 E 559,699

Surface Elevation: $1898 \mathrm{~m}(6227 \mathrm{ft})$

Total Depth: $640 \mathrm{~m}(2100 \mathrm{ft})$

$91 \mathrm{~m}$ (300 ft) Ammonia Tanks Member of the Timber Mountain Tuff. Bedded reworked tuff; vitric, crystal-rich. Sample consists of cuttings wherein calcite is present as secondary microcrystalline cement-like impregnations disseminated throughout the tuff matrix.

Borehole UE-20f

Location: N 917,825 E 552,007

Surface Elevation: $1864 \mathrm{~m}(6116 \mathrm{ft})$

Total Depth: $4171 \mathrm{~m}(13,686 \mathrm{ft})$

2641 m (8665 ft) Rhyolite of Split Ridge. Phenocryst-poor, reddish-brown devitrified, silicified rhyolite. Highly fractured, with abundant $\mathrm{Mn}$ - and Fe-oxide minerals occurring on fracture surfaces. Calcite occurs on these fractures as sparse, thin $(<1 \mathrm{~mm})$ coatings.

4168 m (13674 ft) Peralkaline Rhyolite lava (Pre-Silent Canyon caldera). Yellowish-gray to lt. gray, devitrified, aphanitic, well-indurated. Alteration minerals include sericitc, cpidotc, chlorite and pyrite. Secondary minerals on fracture surfaces include calcite + Fe-oxides + chalcedony + clays. Calcitc occurs as blocky, dense fracture fillings. 